\title{
Drafting a Federal Balanced Budget Amendment That Does What It Is Supposed to Do (And No More)
}

Theodore P. Seto ${ }^{+}$

\section{CONTENTS}

I. What IS THE AMENDMENT SuPPOSED to Do? . . . . . . . 1457

A. Why a Balanced Budget? . . . . . . . . . . . . 1457

1. Institutional Responsibilit . . . . . . . . . . . 1458

2. Intergenerational Equity' . . . . . . . . . . . . 1460

3. Economic Prudence ................. 1463

4. Reconciling Competing Values .............. 1464

B. Why a Constitutional Amendment? . . . . . . . . . . . . 1464

C. Other Normative Issues . . . . . . . . . . . . . . . . . . 1469

1. Enforceability .................. 1469

2. Flexibility .................... 1471

3. Political Neutrality . . . . . . . . . . . . . . 1475

4. Constitutional Nondisruption ... . . . . . . . . 1477

II. Defining the Budgetary Target . . . . . . . . . . . . . 1478

A. Accounting for Spending and Income . . . . . . . . . 1479

1. Treatment of Unpaid Obligations . . . . . . . . . 1483

2. Treatment of Capital Expenditures and Receipts . . . . . 1485

3. What is Cash? .................... 1488

4. What is Debt? . . . . . . . . . . . . . . . . . 1489

5. Constitutional Implications of a Choice of Accounting Methods .................... 1492

B. Scope of the Amendment .................. 1493

C. When to Test ................... 1501

$\doteqdot$ Associate Professor, Loyola Law School, Los Angeles. The author would like to thank Bryan Adamson, Keith Aoki, Ellen Aprill, Bill Araiza. Michael Asımow. David Bureham, Roben Chang. Bı!l Dauster, Catherine Fisk, Victor Gold. Jodi Grant, Chris Kanıos. Mlıchael Knoll. David Leonard. Kasl Manheim, Chris May, Ed McCaffery, Maria Ontiveros, Kalle Pralt. Sean Scoll. Dr. Eugene Steuerte. Paul Treusch, and Georgene Vairo for their comments on preliminary drafis and Lynnelle Avaness. Vickse Cameron, and John Yang for their dedicated and able research assistance. 
D. Accommodating Fiscal Policy ..... . . . . . . . 1504

III. How to Get There . . . . . . . . . . . . . . . . . 1506

A. Setting Annual Targets and Deciding Whether They Have Been

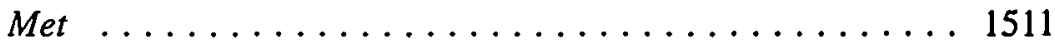

B. Imposing a Remedy ................... 1515

1. Debt Ceiling Limitations . . . . . . . . . . . . . 1516

2. Predefined Default Solutions ............... 1519

3. Process-Based Solutions . . . . . . . . . . . . . 1523

4. Incentive-Based Solutions . . . . . . . . . . . . 1525

5. Who Should Decide? ................ 1526

C. Waiving the Amendment: Who, When, and How? ...... 1530

IV. Conclusion ......................... 1534

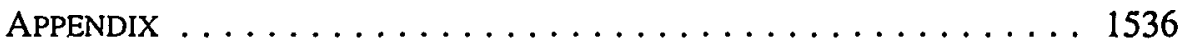


"[I]n constitutional matters, as in others, the devil is in the details."

Efforts to propose and ratify a constitutional amendment to balance the federal budget have been ongoing for almost twenty years, ${ }^{2}$ culminating in the

1. Laurence H. Tribe, How to Violate the Constiution Without Really. Tring: Lessons from the Repeal of Prohibition to the Balanced Budget Amendment, 12 CONST. COMMENTARY 217, 218 (1995).

2. See, e.g., S. REP. No. $104-5$ (1995) (recommending adoption of balanced budget constututional amendment); H.R. REP. No. 104-3 (1995) (same); S. REP. No. 103-163 (1993) (same): S. REP. No. 102. 103 (1991) (same); S. REP. No. 101-391 (1990) (same); S. REP. No. 99.163 (1985) (same); S. REP. No. 98-628 (1984) (recommending adoption of balanced budgev/ax limitation constututional amendment); $S$. REP. No. 97-151 (1981) (same); STAFf OF HOUSE COMM. ON THE BUDGET, IOSTI CONG.. IT'S NOT the MONEY, IT'S THE PRINCIPLE: RESTORING THE RIGHT DEBATE ABOUT A BALANCED BLDGET AMENDMENT (Comm. Print 1995) (same); see also The Balanced Budget Amendment: Hearngs Before the Joint Economic Comm., 104th Cong., Parts I \& II (1995) [hereinafter 1995 Jount Hearngs]; Balanced Budget Constitutional Amendment: Hearings on H.J. Res. I Before the Subcomm. on the Constitution of the House Comm. on the Judiciary, 104th Cong. (1995) [hereinafter 1995 House Hearngs]: Balanced Budget Amendment to the Constitution: Hearing on S.J. Res. AI Before the Subcomm. on the Constutuon of the Sen. Comm. on the Judiciary, 103d Cong. (1995) (heanng held in 1994) (hereinafter 1994 Senate Judiciar Comm. Hearings]; Balanced Budget Amendment: Hearmgs on S.J. Res. 11 Before the Senate Comm. on Appropriations, 103d Cong. (1994) [hereinafter 1994 Senate Approprattons Comm. Hearings). Constitutional Amendment to Balance the Budget: Hearings Before the Sen. Comm. on the Budget, 102d Cong. (1992) [hereinafter 1992 Senate Hearings]: Balanced Budger Constutuonal dmendment. Hearing on S.J. Res. 13 Before the Subcomm. on the Constitution of the Sen. Comm. on the Judictan. 99 th Cong (1985) [hereinafter 1985 Senate Hearings]: The Balanced Budget Amendment: Hearng Before the Joint Economic Comm., 98th Cong. (1985) (hearing held in 1984) [herenafter 1984 Joint Hearng]: Proposed Balanced Budget/Tax Limitation Constiturional Amendment: Hearing on S.J. Res. 5 Before the Subcomm. on the Constitution of the Sen. Comm. on the Judictary, 98th Cong. (1984) (heanngs held in 1983 and 1984) [hereinafter 1983-84 Senate Hearing]; Constitutional Amendments Seekng to Bulance the Budget and Limit Federal Spending: Hearings Before the Subcomm. on Monopolies and Commercul Law of the House Comm. on the Judiciary, 97th Cong. (1983) (heanngs held in 1981 and 1982) lhereanafter 198J-82 House Hearings]; Balancing the Budget: Hearing on S.J. Res. 58 Before the Subcomm. on the Consututton of the Sen. Comm. on the Judician;, 97th Cong. (1982) (heanng held in 1981) (hereinafter 198/ Second Senate Hearing]; Balanced Budget-Tax Limitation Constutuonal Amendment. Hearngs on S.J Res. 9. S.J. Res. 43, and S.J. Res. 58 Before the Subcomm. on the Consulutron of the Sen. Cormm. on the Judicturn, 97th Cong. (1981) (hereinafier 198/ First Senate Hearings): Constiutional Amendments to Bulance the Federal Budget: Hearings Before the Subcomm. on Monopolies and Commertul Lenv of the House Comm. on the Judiciary, 96th Cong. (1980) (hearings held in 1979 and 1980) /heresnafter 1979-30 House Hearings]; CONGRESSIONAL BUDGET OFFICE, BALANCING THE FEDERAL BUDGET AND LIMITING FEDERAL SPENDING: CONSTITUTIONAL AND STATUTORY APPROACHES (Sept. 1982).

Indeed, the Senate considered a balanced budget amendment as far back as 50 years ago. See $S$ REP No. 80-154 (1947) (recommending proposal of balanced budget constututional amendment) For a more complete history of congressional effors to propose a balanced budget amendment. see JAMES $V$ SATURNo, A BALANCEd BUDGET CONSTITUTIONAL AMENDMENT: BACKGROUND AND CONGRESSIONAL OPTIONS 13-23 (Congressional Research Serv., Dec. 1994), and David E. Kyvig. Refining or Resising Modem Government? The Balanced Budget Amendment to the U.S. Constutution. 28 AKRON L. REY 97 (1995) (documenting history of balanced budget amendment attempts). In addition to congressional efforts. a majority of state legislatures have either requested that Congress propose a balanced budget amendment, or applied for Congress to convene a constitutional convention for this purpose. See S. REP. NO 97-151. at 12-13; RUSSELL L. CAPLAN, CONSTITUTIONAL BRINKSMIANSHIP: AMENDING THE CONSTITLTION BY NATIONAL CONVENTION 78-89 (1988) (reviewing history of calls for convention to propose balanced budget amendment); WILBUR EDEL, A CONSTITUTIONAL CONvENTION: THREAT OR CHALLENGE? 69-76 (1981) (reviewing history of calls for convention to propose balanced budget amendment and concluding that Congress should establish regulations for such convention): SATURNo. supra, at 21-23. PAUL J WEBER \& BARBARA A. PERRY, UNFOUNDED FEARS: MYTHS AND REALITES OF a CONSTITUTIONAl CONVENTION 127-40 (1989) (reviewing arguments for and against balanced budget amendment and concluding that convention route is safe and appropriate); E. Donald Eliout. Consurultonal Conventrons and the Deficu. 1985 DUKE L.J. 1077 (arguing that convention is appropnate vehucle to address balanced budget problem) 
repeated narrow defeat of Senate Joint Resolution 1 (the "1995-96 Senate Draft") ${ }^{3}$ in March 1995 and June 1996. History suggests that the same draft, or one very similar, will be introduced again. Recent shifts in the makeup of Congress have increased the likelihood of passage. ${ }^{4}$ In any event, proposals for a federal balanced budget amendment are likely to remain politically central for the foreseeable future.

Most of the public debate on this issue has centered around whether such an amendment, in the abstract, is a good idea; ${ }^{5}$ little has been written about the formidable technical problems involved in drafting a balanced budget amendment that does what it is supposed to do. $^{6}$ This is, perhaps,

A political history of the balanced budget issue can be found in JAMES D. SAVAGE, BALANCED BUdGets \& AMERICAN POLITICS (1988) (describing history of budgetary balance as political issue).

3. S.J. Res. 1, 104th Cong. (1995). The text of the resolution, as finally amended, is attached to this Article as an Appendix. In March 1995, the resolution failed in the Senate on a vote of 65 to 35 in favor of passage. See 14I CONG. REC. S3314 (daily ed. Mar. 2, 1995). A favorable vote of 67 is required to submit the proposed amendment to the states for ratification. See U.S. CONST. art. V. Because Senator Robert Dole voted against the resolution only to preserve the option of moving for reconsideration later in the session, see 141 CONG. REC. S3827, S3829 (daily ed. Mar. 13, 1995), the vote was effectively 66 to 34 . In June 1996 , the resolution failed again on a vote of 64 to 35 . See 142 CONG. REC. S5873, S5903 (daily ed. June 6, 1996).

4. See, e.g., Alan Fram, Balanced Budget Foes Not Giving Up, Charleston Gazette \& Dally Mall, Nov. 17, 1996, at $3 A$ (suggesting that two-thirds majorities to adopt amendment probably exist).

5. See, e.g., 141 CONG. REC. S3340-41 (daily ed. Mar. 2, 1995) (statement of Sen. Craig) (entering into record article that reports over 200 economists support amendment); id. at $\$ 2119$ (daily ed. Feb. 3 , 1995) (statement of Sen. Moynihan) (asserting that more than 450 economists, including seven Nobel Laureates, oppose amendment); RiCHARD E. WAGNER ET AL., BALANCED BUDGETS, FISCAL RESPONSIBILITY, AND THE CONSTITUTION (1982) (arguing for constitutional amendment); $A$ Sense of Balance, ECONOMIST (London), Mar. 11, 1995, at 18 (opposing amendment as inviting judicial intervention in economy); Marc Breslow, Balanced-Budget Amendment Is a Disaster Waiting to Happen, BuFp. NEws, Feb. 28, 1995, at B3 (economist and editor of Dollars and Sense magazine arguing against amendment); Daphne Greenwood, What if Congress Had Passed Balanced-Budget Amendment?, DENv. POST, May 27, 1995, at B11 (economist and former legislator evaluating pros and cons of amendment); Robert T. Nelson, Balanced-Budget Amendment Would Have Big Impact Here, SEATTLE TIMES, Mar. 2, 1995, at Al (assessing likely impact of amendment in Washington State); Jane Bryant Quinn, Balanced-Budget Amendment Served as Smoke Screen for Weak Politicians, BUFF. NEWS, Mar. 11, 1995, at B 11 (economistcolumnist opposing amendment as sham); William Safire, Balance That Budget, N.Y. Times, Feb. 27, 1995, at A15 (columnist supporting amendment); Shalikashvili Warns Against Balanced Budget Amendment, 173 AEROSPACE DAILY 312 (1995) (conveying Chair of Joint Chiefs of Staff's warning that amendment will lead to reduced defense budget). For representative essays on this question, see BALANCING ACT-DEBT, DEFICITS, AND TAXES (John H. Makin et al. eds., 1990). For essays on balanced budgets generally and balanced budget amendments, see A NATION IN DEBT: ECONOMISTS DEBATE THE FEDERAL BUDGET DEFICIT (Richard H. Fink \& Jack C. High eds., 1987), and THE FEDERAL DEFICIT (Andrew C. Kimmens ed., 1985).

6. The scholarly legal literature is surprisingly sparse, given the topic's importance and the length of time it has been a serious political issue. The literature that does exist focuses primarily either on the question of judicial enforcement or on arguments for or against adoption. See James W. Bowen, Enforcing the Balanced Budget Amendment, 4 SETON HALL. CONST. L.J. 565 (1994) (arguing that amendment would be susceptible to judicial enforcement); David Dreier \& William Craig Stubblebine. The Balanced Budget/Tax Limitation Amendment, 10 HASTINGS CONST. L.Q. 809 (1983) (arguing in favor of amendment): Peter W. Rodino, Jr., The Proposed Balanced Budget/Tax Limitation Constitutional Amendment: No Balance, No Limits, 10 Hastings CONST. L.Q. 785 (1983) (Chair, House Committee on the Judiciary. arguing against amendment); Donald B. Tobin, The Balanced Budget Amendment: Will Judges Become Accountants? A Look at State Experiences, 12 J.L. \& POL. 153, 155-71 (1996) (reviewing state court decisions construing state balanced budget provisions); Gay Aynesworth Crosthwait, Note, Article III Problems in Enforcing the Balanced Budget Amendment, 83 COLUM. L. REV. 1065 (1983) (noting that 
understandable. The scholarly community tends to defer technical analysis until after an amendment clears Congress. Proposals for a federal balanced budget amendment present further problems. First, they implicate two fields not usually linked: constitutional law and accounting. Few constitutional scholars feel comfortable tackling accounting issues; ${ }^{7}$ accountants, in turn, do not often write about the Constitution. Second, there is a dearth of satisfactory models from which to work: Amendment proponents perceive the Gramm-RudmanHollings $\mathrm{Act}^{8}$ and other legislative approaches ${ }^{9}$ as inadequate, ${ }^{10}$ and the

amendment raises justiciability problems); David Lubecky. Comment, The Proposed Federal Balanced Budget Amendment: An Inquiry into Appropriateness, 55 U. CIN. L. REV. 563 (1986) (describung state experience with judicial enforcement); Lavinia L Mears. Note. The Truh About the Balanced Budget Amendment, 20 SETON HALL LEGIS. J. 592 (1996) (arguing aganst amendment): Note. The Balanced Budget Amendment: The Lesson from State Expenence. 96 HARV. L. REV. 1600 (1983) (claumung that amendment is inappropriate) [hereinafter State Expenence]. A number of constitutional scholars have testified in hearings on such an amendment, but aimost exclusively on constututional issues. See, e.g., 199s Senate Appropriations Comm. Hearings, supra note 2, at 81-92 (statement of Professor Charles Fned); ud. at 131-48 (statement of Walter Dellinger, Assistant Attomey General); id. at 149-62 (statement of Professor Archibald Cox); id. at 162-76 (statement of Nicholas Katzenbach. former Attomey General. Johnson Administration); id. at 177-93 (statement of Professor Kathleen Sullivan); td. at 193-207 (statement of Professor Burke Marshall); 1994 Senate Judicicn. Comm. Hearnigs. supra note 2. al $7 \$ 78$ (statement of Stewart E. Sterk); 1992 Senate Hearings, supra note 2, at 5-48 (stalement of Professor Liurence H. Inbe): id. at 73-93 (statement of Professor Walter Dellinger): 1983-84 Senate Hearning. supra note 2, at 29-35 (statement of Professor John T. Noonan, Jr.); id. at 79-85 (statement of Professor Robert D. Goldstein). Preliminary discussion of some of the technical issues rased in this Antıcle appears in SAT'R:O. supra note 2, at 29-41 (discussing use of estimates. supermajority requirements. impoundment power. off-budget activity, waivers, definition of debt, tax or expenditure limitations, judicial review, and ltem veto). and WAGNER, supra note 5, at 29-35 (discussing off-budget activity, captlal budgets. and annual targets)

7. The 1995-96 Senate Draft was drafted primarily by the staffs of the House and Senate Judiciary committees, without significant input from the staffs of the respective Budget committes. Interview with William Dauster, Minority Staff Director, Senate Budget Commıttee, in Washıngton, D C (Jan 5, 1997)

8. Balanced Budget and Emergency Deficit Control Act of 1985. Pub. L. No 99.177. 99 Stat. 1038. as amended by Balanced Budget and Emergency Deficit Reduction Reaffirmation Act of 1987. Pub L. No 100-119, 101 Stat. 754. For analyses of Gramm-Rudman-Hollings, see EDWARD Davis \& ROBERT Kertit. DEBT-LIMIT INCREASE AND 1985 BALANCED BUDGET ACT REAFFIRMATION: SUMMART OF PLbLIC LAW' 100-119 (H.J. RES. 324) (1987), and Kate Stith, Rewrinng the Fiscal Consmumon: The Case of GrammRudman-Hollings, 76 CAL. L. REV. 593 (1988).

9. A history of other legislative approaches to the deficil control problem can be found in SATL R.O. supra note 2, at 25-28.

10. See, e.g., 141 CONG. REC. H628-29 (daily ed. Jan. 25. 1995) (statement of Rep Hyde) ("In the past 10 years, three major legislative efforts have sought to reverse the Govemrnent's chrontc defict pattern. Two of them have failed and the third is destined to do so."); Joseph Biden. Whs / Swithed. $\mathrm{X} Y$ TIMES, Feb. 25, 1995, $\S 1$, at 23 (assering that Gramm-Rudman-Hollings falled). Robert Dole, Whs We Need a Balanced-Budget Amendment, WASH. TIMES, Fcb. 28. 1995, al A21 (staung that we need to "fein in big government"); Chip Drury, Editorial, Balanced-Budget Amendment Will Counter "Futal Auractun" of Profligacy, WASH. TIMES, Feb. 28. 1995. at A20 (arguing that falure of Act requires balanced budgel amendment); Safire, supra note 5, at 4 (asserting that "budget-balancing statutes afe hot alr"). Dick Thornburgh, Out of Balance. Still America Needs a Balanced-Budget Amendment to Pronte Fiscal Discipline, PITT. POST-GAZETTE, June 11, 1996, at A15 (referning 10 Gramm-Rudman-Hollıngs as "nowdefunct"). Assessments of the efficacy of the Gramm-Rudman-Hollings Act in the scholasly legal literature have been mixed. See, e.g., Pete V. Domenici. The Gramm-Rudman-Hollmgs Budget Process An dat of Legislative Futility?, 25 HARV. J. ON LEGIS. 537 (1988) (arguing that Aci's record is good): Thomas J Downey, The Futility of Gramm-Rudman-Hollings, 25 HARV. J. ON LEGIS. S.45, 552 (1988) (concluding that Act cannot work); John W. Ellwood. The Politics of the Enaciment and Implementanon of Gramm. Rudman-Hollings: Why Congress Cannot Address the Defict Dilemma. 25 HARY. J. ON LEGIS 553, 574 (1988) (arguing that "design of [ACt] also illustrates the difficulty of designing a credible semi-autonomous doomsday machine"); Robert W. Kasten, Jr., Gramm-Rudman-Hollungs: Ant Imperfect Law Thut Works, 25 
experiences of states with similar constitutional provisions remain controversial. " Finally, analysis of balanced budget amendment drafts has been hampered by the differing motives of its proponents. For some, the goal is simply to require a balanced federal budget. For others, the goal appears to be to limit the size and power of the federal government-to enact, in effect, an "antifederalist" amendment to the United States Constitution. ${ }^{12}$ These

HARV. J. ON LEGIS. 577, 577 (1988) (arguing Act "has imposed a measure of fiscal discipline"); Dan Quayle, Is Gramm-Rudman-Hollings an Exercise in Legislative Futility?, 25 HARV. J. ON LEG1S. 587 (1988) (asserting that to date, Act has succeeded); Randall Strahan, Governing in the Post-Liberal Era: GrammRudman-Hollings and the Politics of the Federal Deficit, 25 HARV. J. ON LEGIS. 593, 607 (1988) (noting that it is impossible to predict whether Congress will meet future Act targets); Dick Thornburgh, GrammRudman-Hollings and the Balanced Budget Amendment: A Page of History, 25 HARV. J. ON LEGIS. 611, 611 (1988) (arguing that Act will probably fail and constitutional amendment is needed); Howard Levkowitz, Note, The Gramm-Rudman-Hollings Act: A Styrofoam Damocles' Sword?, 2 S. CAL. INTERDISC. L.J. 367, 392 (1993) (assessing legislation passed since Act and concluding that while Act has had some impact, it is now of "decreased importance"); Gary A. Loxley \& Thomas F. Mitola, Comment, The Congressional Budget and Impoundment Control Act of 1974: Gramm-Rudman and Beyond, 14 OHIO N.U. L. REV. 329, 330 (1987) (calling 1974 Congressional Budget and Impoundment Control Act "a dismal failure" and asserting that Gramm-Rudman-Hollings "has not been successful").

11. Compare CONGRESSIONAL BUDGET OFFICE, supra note 2, at 117-28 (arguing that notwithstanding state constitutional limitations, state borrowing increased more rapidly than federal debt over prior 20 years and concluding that: "State experience offers meager support for the expectation that constitutional restrictions will constrain governmental borrowing."), and A. JAMES HEINS, CONSTITUTIONAL RESTRICTIONS AGAINST STATE DEBT at vii, 27 (1963) (concluding that state legislatures are generally able to circumvent constitutional debt restrictions), and B.U. RATCHFORD, AMERICAN STATE DEBTS 7-8 (1941) (noting frequent attempts by states to evade constitutional debt limits), and D. Roderick Kiewiet \& Kristin Szakaly, Constitutional Limitations on Borrowing: An Analysis of State Bonded Indebtedness, 12 J.L. ECON. \& ORG. 62,62 (1996) ("'C]urrent proposals for constitutional limitations on borrowing at the federal level would have much less impact on total government borrowing than their proponents anticipate."), and C. Robert Morris, Jr., Evading Debt Limitations with Public Building Authorities: The Costly Subversion of State Constitutions, 68 YALE L.J. 234 (1958) (reviewing methods of circumvention), with S. REP. No. 104-5, at 11 (1995) (asserting that state experience has been successful), and W. Mark Crain \& James C. Miller III, Budget Process and Spending Growth, 31 WM. \& MARY L. REv. 1021, 1044 (1990) (noting that constitutional balanced budget requirements "significantly slow spending growth" in states where budget is initiated in legislature, but not in states where budget is initiated by executive), and Stewart E. Sterk \& Elizabeth S. Goldman, Controlling Legislative Shortsightedness: The Effectiveness of Constitutional Debt Limitations, 1991 WIS. L. REv. 1301, 1302 (arguing that "constitutional debt limits, even if often underenforced, have served effectively to protect against the worst sorts of legislative abuse"). Although states have generally met the formal requirements of their respective constitutional provisions, it also appears that state spending not subject to those provisions has grown very substantially. Whether a formally respected but routinely circumvented provision should be viewed as successful is questionable. A collateral cost of ineffective debt limitation provisions is sometimes to raise interest and other transaction costs to the governmental bortower. See CHARLES N. HENNING ET AL., FINANCIAL MARKETS AND THE ECONOMY 256-57 (3d ed. 1981). In such event, the net effect of the provisions is to increase, not decrease, the state's overall deficit.

12. See, e.g., 1995 House Hearings, supra note 2, at 93 (statement of William P. Barr, Former Attorney General, Department of Justice) (asserting that balanced budget amendment is needed to reduce size of federal government); id. at 107 (statement of William A. Niskanen, Chairman, Cato Instituto) (arguing that balanced budget amendment limits federal powers, consistent with original purpose of Constitution); id. at 226 (statement of Rep. Solomon) (arguing that balanced budget amendment is needed to reduce size of federal government); 1995 Joint Hearings Part I, supra note 2, at 17-18 (statement of Sen. Grams) (same); id. at 25 (statement of Lewis K. Uhler, President, National Tax Limitation Committee) (same); id at 64 (statement of Professor Milton Friedman, Economist) (same); 1995 Joint Hearings Parf II, supra note 2, at 65 (statement of Rep. Mica) (same); 1994 Senate Judiciary Comm. Hearings, supra note 2, at 24 (statement of Martin A. Regalia, Vice President and Chief Economist, U.S. Chamber of Commerce) (same); id. at 30-33 (statement of David M. Stanley, President, National Taxpayers Union) (same); 1983-84 Senate Hearing, supra note 2, at 32-35 (statement of Professor John T. Noonan. Jr.) (same); id. 
different goals raise different technical problems and invite technical imprecision.

In any event, balanced budget amendment drafts have not evidenced adequate attention to technical detail. The 1995-96 Senate Draft, for example, seems to have been written with primarily political, not technical, considerations in mind. Not surprisingly, close analysis reveals serious technical flaws. Without greater attention to technical detail, future proposals are likely to perpetuate those flaws. This would be unfortunate. A poorly drafted amendment might facilitate nominal compliance-that is, literal compliance with an inadequate numerical test-while failing to require adherence to the underlying values that the amendment is supposed to protect. Nominal compliance with a poorly drafted amendment might, in turn, provide political cover for continued budgetary irresponsibility. A poorly drafted amendment might also trigger or exacerbate economic instability. At worst, such an amendment might even cause a meltdown of the world's financial system. In sum, a poorly drafted amendment could trigger a series of economic and constitutional crises while leaving unsolved the problem it was ostensibly intended to address. ${ }^{13}$

This Article will not attempt to address whether either a balanced budget or a constitutional amendment to require one is a good idea. ${ }^{4}$ Nor will it explore the technical problems that would need to be resolved by a well-

at 255-56 (statement of American Farm Bureau Federatuon) (same); Id. at 312-16 (statement of Professor Milton Friedman, Senior Research Fellow, Hoover Instituton) (same): 198/-82 House Hearings, supra note 2, at 320-21 (statement of Hon. Donald T. Regan. Secretary of the Treasury): 1979-80 House Hearings. supra note 2, at 71 (statement of James Dale Davidson. Chairman. National Taxpayers Union) (same); ud. at 275 (statement of Allen Schick, Congressional Researeh Service) ("[T]he proposed spending limitalions mask their real purpose, a radical transformation in the character, reach, and purpose of the United States Government."); id. at 364 (statement of Rep. Gingrich) (arguing that balanced budget amendment is needed to reduce size of federal govemment): S. REP. No. 104-5. at 5 (1995) (statung that existing constitulional provisions have "failed to limit the voracious appetite of Congress to legislate into every area of private concern, to invade the traditional bailiwick of the States, and. consequently. to spend and spend to fund these measures until the Federal Government has become functionally insolvent and the ceonomy is placed in jeopardy"); S. REP. NO. 97-151, at 38 (1981) ("[T]he Federal government has grown to become the dominant economic institution in the United States.").

13. For example, as I discuss later, a cash method amendment might lead legislators to bid for votes by committing the government to unfunded future expenditures, see infra Subsection 11.A.1. bias legislatuve decisionmaking in favor of short-term solutions, see infra Subsection 11.A.2: tempt Congress to authonze the creation of quasicash, see infra Subsection Il.A.3; or lead to more extensive use of informal debt, see infra Subsection II.A.4. An amendment that failed to control the use of off-budget enutues might lead to a proliferation of government programs not subject to the appropriations process. See infra Section Il.B. An amendment that failed to limit congressional action directly might continue to permit legislatıve irresponsibility, leaving others to pick up the pieces. See infra Section II.C. An amendment that falled to take economic conditions into account might exaggerate the business cycle and worsen economic downtums. See infra Section II.D. An amendment enforced by a debt ceiling limitation mechanism might lead to default on the national debt, which might in turn lead to economic collapse. see infra Subsection III.B.1; alternatively, it might lead to effective unenforceability and a further decline in public confidence in American government, see id.

14. For the existing scholarly legal literature on this question, see supra note 6. 
drafted antifederalist amendment. ${ }^{15}$ Instead, it will focus on the technical problems presented in drafting, implementing, and interpreting an amendment, the goal of which is simply to require a balanced federal budget. At first glance, these problems may appear ministerial: details that members of Congress and constitutional scholars may be tempted to leave to others. Their resolution, however, has profound implications for the success of the amendment and the structure of American government. Even the broadest issues cannot be understood or thoughtfully addressed without attention to technical detail.

There is, of course, no single technically correct approach to most complex policy issues. Technical competence must serve broader goals. In Part I, I will explore what a balanced budget amendment is supposed to do. I will first examine why we want balanced budgets at all; the answers, I suggest, should influence how we define our budgetary target. Second, I will review current theories as to why a constitutional amendment may be necessary; again, identification of perceived procedural or other defects in current decisionmaking processes may shed light on the procedural or other enforcement mechanisms an effective amendment might need to institute. Finally, I will posit four additional normative characteristics of any welldrafted federal balanced budget amendment: (1) a balanced budget amendment should be enforceable; (2) it should nevertheless permit carefully delimited degrees of flexibility in its application; (3) it should be politically neutral - that is, it should not change or distort political decisionmaking, intentionally or inadvertently, except to require a balanced budget; and (4) it should not disrupt our existing constitutional system except as is absolutely necessary to accomplish its purposes. Some will disagree with these premises. My goal in Part I is not necessarily to persuade the reader that I am right. It is rather to urge greater attention to normative premises, to challenge those who disagree to be explicit in their disagreement and in their analysis of the implications of different normative assumptions for technical structure.

In Part II, I will then address a first set of technical problems, those involved in defining the budgetary target. I will examine four issues: choice of accounting methods; scope of the amendment; when in the budgetary process the amendment should test compliance; and how well the amendment accommodates fiscal policy. Failure of an amendment to address the first three thoughtfully, I will argue, may permit Congress to comply nominally while largely frustrating the amendment's ultimate purposes. Failure to accommodate fiscal policy adequately may result in economic destabilization and possibly economic catastrophe. I will conclude that the solution adopted in the 1995-96 Senate Draft is deficient in both these respects.

15. A preliminary examination of technical questions raised by tax and spending limitation provisions appears in SATURNo, supra note 2, at 37-40. 
Finally, in Part III, I will examine three major procedural problems in enforcement: who interprets and defines the budgetary target and determines whether it has been met, how a violation of the requirements of the amendment is remedied, and how and in what circumstances the requirements of the amendment may be waived. First, I will conclude that if the amendment is to be effective, the rules used to define the target and decide whether the target has been met must be subject to outside review by an independent scorekeeper. Second, I will review possible solutions to the problem of remedy, with special attention to those incorporated in the 1995-96 Senate Draft, and conclude that there is currently no fully satisfactory solution to the problem. Finally, I will argue that waiver of the amendment should be permitted by supermajority legislative vote, but without the exceptions some have suggested for economic emergencies. I will conclude that the solutions to important enforcement issues adopted in the 1995-96 Senate Draft are flawed in important respects.

I do not claim to have all the answers. I do bring an unusual perspective to the problem: For most of my professional life I have worked with financial anticircumvention rules-the rules of the Internal Revenue Code-and with the analytic methods of tax policy, which, like a balanced budget amendment, often attempts to induce behavioral change along one axis without distorting behavior along others. Viewed from this perspective, some balanced budget amendment issues are currently susceptible to sound iechnical resolution. Others require further work. I conclude, however, that any broadly acceptable, technically sound balanced budget amendment would differ significantly from the 1995-96 Senate Draft in ways that neither proponents nor opponents have yet fully considered.

\section{What IS ThE AMENDMENT SUPPOSED to DO?}

\section{A. Why a Balanced Budget?}

I do not propose to undertake a critical examination of the arguments for or against a balanced budget. My purpose here is much more limited. Assuming that we as a nation decide to mandate balanced federal budgets, we should identify our reasons clearly, so as to permit the drafting of a budgetary target consistent with those reasons. Proponents make many arguments in favor of a balanced budget. Ultimately, I suggest, they reflect three principal values, with sometimes inconsistent implications for the definition of budgetary targets. ${ }^{16}$

16. Some proponents appear to support a balanced budget amendment as an indirect technique for constraining federal spending. See supra note 12. The technical problems of proposals to constrain federa! spending are beyond the scope of this Article. Section 1.A therefore focuses on arguments in favor of budgetary balance itself, not in favor of budgetary balance as an indirect means to a uffferent polttical cnd 


\section{Institutional Responsibility}

One of the most common arguments in favor of a balanced budget is to avoid national "bankruptcy."17 Technically, of course, national governments cannot declare bankruptcy, which generally denotes a procedure through which governments absolve private debtors of their debts. ${ }^{18}$ The term "insolvency" 19 is no more helpful. If "insolvency" means an excess of liabilities over assets, the United States Government is deeply insolvent and has been so since before $19600^{20}$ The relationship between a national government's nominal assets and liabilities, however, has little practical significance; a government's assets are not generally available to satisfy its liabilities. ${ }^{21}$ A second common meaning of "insolvency" is an inability to pay debts as they come due. Since the United States has not publicly defaulted on its debts for over two centuries, ${ }^{22}$ under this measure the United States is not now and is unlikely ever to become insolvent-unless, of course, Congress renders it unable to pay its debts by refusing to increase the debt limit.

Those worried about national "bankruptcy," however, probably do not intend to invoke a technical meaning. At some point, high levels of debt and debt service threaten the viability of all financial organizations, including

17. See, e.g., 1995 House Hearings, supra note 2, at 240-46 (statement of James D. Davidson, Chairman, National Taxpayers Union) (arguing that balanced budget is needed to avoid national "bankruptcy"); 1984 Joint Hearing, supra note 2, at 1 (statement of Sen. Jepsen) ("Without some kind of institutional reform to limit tax and spending growth, this situation will drive us into national bankruptcy"): James Dale Davidson, Amendment for the Info Age, INVESTOR's Bus. DAlLY, Jan. 27, 1995, at A2 ("The only question is whether the deficits will be curtailed by constitutional remedy, bankruptcy or revolution."); Mike DeWine, The Balanced Budget Amendment Is America's Last Chance for Fiscal Security, DAYTON DAILY NEwS, Feb. 28, 1995, at 11A (stating that five trillion dollar debt "threatens our children's generation with bankruptcy"); Rick Santonum, Sen. Hatfield, as a Committee Chairman, Was Obliged to Vote with His Party, PITT. POST-GAZETTE, Apr. 2, 1995, at F2 (arguing that balanced budget amendment is necessary to curb "insatiable need to spend our future into bankruptcy"). But see Paul W. McCracken, Falling Dollar? Blame the Deficit, WALL ST. J. EuR., Apr. 21, 1995, at 6 ("[O]ne extreme . . . is the view that the public debt will mount to the point where there is some sort of national bankruptcy that leaves the whole economy disintegrated and on the trash heap. . . . At the other extreme there is the view that budget and debt worries are vastly overblown....").

18. See RICHARD Rose \& GUY PETERS, CAN GOVERNMENT Go BANKRUPT? 7-8 (1978).

19. See, e.g., S. REP. No. 104-5, at 3 (1995) (describing America as "functionally insolvent"); America the Insolvent: Reconsidering a Balanced Budget Amendment, SAN DIEGO UNION-TRIB., June 5, 1996, at B6 (arguing in favor of balanced budget amendment); Robert J. Caldwell, Tax and Spend Win a Pyrrhic Victory Over Republicans, SAN DIEGO UNION-TRIB., Mar. 5, 1995, at GI ("No nation valuing its solvency ... could afford such a massive accumulation of debt.").

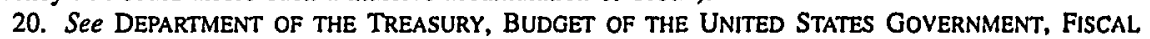
YEAR 1997, ANALYTICAL PERSPECTIVES 18 (1996).

21. A more pertinent inquiry might be whether the nation's external debt exceeds current assets available to service and redeem that debt. A nation insolvent in this regard faces a real and immediate threat to its independence. Such an inquiry, however, is not directly relevant to the definition of a balanced budget target. A significant portion of the United States's external debt is privately issued; the federal deficit is therefore only one, and probably not the most important, determinant of the amount of that debt.

22. See James J. Angel, Looking Back at Debt Defaults in U.S. History, CHI. TRIB., Feb. 1, 1996, at 21 (observing that last governmental default on principal occurred in 1787, although paperwork problems and computer failures led to late payments in 1979). 
national governments. Some historians believe that the French ${ }^{23}$ and Russian $^{24}$ revolutions were triggered in part by unsustainable national debt levels, ${ }^{25}$ in each case leading to a radical reshaping of Western civilization. The Weimar Republic in Germany, the collapse of which permitted Adolf Hitler's rise to power, suffered from the same problem. ${ }^{26}$ In the modern world, national "bankruptcy" of smaller economies commonly leads to a partial loss of sovereignty when international assistance is conditioned on changes in domestic policy. ${ }^{27}$ Excessive debt levels cause problems for government, however, long before collapse or loss of sovereignty. A government so burdened is less able to address the concerns of its citizens. ${ }^{2 s}$ This, in turn, adversely affects its ability to govern and its perceived legitimacy. A government struggling under the burden of excessive debt may come to be viewed as ineffective. ${ }^{29}$

It is not clear what level of debt would cause significant problems for the

23. See, e.g.. ALEXIS DE TOCQUEVILLE THE OLD REGIME AND TIE FRENCU RLIOLI TIOS $177-79$ (Stuart Gilbert trans., 1955) (citing govemment debt as major cause of French Resolutun). EJ HOBSBAWM, THE AGE OF REVOLUTION 1789-1848, al 79-80 (1962) (noung that pre-Reiolutionary French debt service constituted half of national budget).

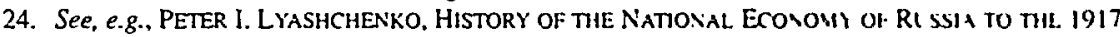
REvolution 768-69 (L.M. Herman trans., 1949) (noting that from 1914 to 1917. Russtan cxpenditures totalled 47 billion rubles while budget deficit exceeded 46 billıon rubles. leading to hypensitation in 1917), RICHARD PIPES, THE RUSSIAN REVOLUTION 23+-36 (1990) (posiulating that war deficits, linanced by papes money and foreign borrowing, led to hyperinflation).

25. See, e.g., CRANE BRINTON. THE ANATOMY OF Revoltmon 28-39 (1965) (argung that Cromwellian Revolution, American Revolution. French Revolutıon. and Russian Revolution were all caused in part by financial difficulty of governments).

26. See, e.g., 1994 Senate Judician. Comm. Hearmgs, supru note 2, at 32 (stalement of David M Stanley, President, National Taxpayers Union) (companng United States with Gernany in 1920s and with present-day Argentina and Brazil); HAROLD G. MOULTON \& LEO PASVOLSKY. WORID WAR DEBT SETTLEMENTS 10-23 (discussing German reparation debl): GLSTAV STOLPER. GERMA ECONOWY 1870-1940: IsSUES AND TRENDS 137-42 (1940) (describıng German reparation pay ment plan) John Maynard Keynes believed that the Weimar Republic's debl service obligatıon was three tumes grealer than its ability to pay. See STOLPER, supra, at 140.

27. See, e.g., Diana E. Moller. Intervention, Coencion, or Jusnfiable Need' A Legal Analssis of Structural Adjustment Lending in Cosia Rica, 2 Sw. J.L. \& TRADE Ast 483. 507 (1995) ("Costa Rica is an excellent example of the difficulties a debtor nation faces when it tnes to mantain its sosereigniy and payments on its debt service simultaneously."); Anthony Galano Ill. Commen, Internattonal Monetan Fund Response to the Brazilian Debr Crisis: Whether the Effects of Condtionalin Hase Indermined Brazil's National Sovereignty, 6 PACE INT'L L. REV. 323 (1994) (concluding that IMF condtionalty dud not violate international law but that dissatisfaction with stnngent conditionalıty polıcies may deral future negotiations). For more general discussions of the role of the World Bank and the Intemational Monetary Fund in the internal policies of debtor nations, see Jerome Levinson, Mtululateral Financing Instutuans What Form of Accountability?. 8 AM. U. J. INT'L L. \& POL'Y 47, 69-71 (1992) (assertung that World Bank and IMF should be made more accountable), and Kim Reisman. Note. The World Bank and the liMfF. At the Forefront of World Transformation, 60 FORDHAM L. REV. S349. S392-94 (1992) (asserting that World Bank and IMF intervention in domestic policies is necessary).

28. The Senate report noted:

Every day, the Government throws away over $\$ 800$ million on interest payments. None of this money goes toward education, health care, or the battle against drugs and cnme. Spending more and more on interest leaves fewer and fewer resources to spend on the goods and services needed to address other, serious problems facing the Nation.

S. REP. NO. 104-5, at 8 (1995).

29. See ROSE \& PETERS, supra note 18, at $|7-4|$. 
United States. Some may argue that we have already reached that point. ${ }^{30}$ In any event, one of the principal arguments for balanced budgets is to avoid the institutional problems created by financial impairment. ${ }^{31}$ Excessive debt weakens government; to maintain a strong federal government, we must require balanced federal budgets. ${ }^{32}$ I will refer to the value implicit in this argument as "institutional responsibility."

Under an institutional responsibility rationale, however, our target will not necessarily be a balanced budget. If we believe that the debt is at unhealthy levels, the rationale implies that we should run surpluses to reduce that debt, not merely balance the budget. Conversely, if we believe that concerns about current debt levels are overstated, it implies that we need not require balanced budgets at all-we should merely monitor the problem. Unfortunately, there is no consensus as to what constitutes a healthy level of national debt.

\section{Intergenerational Equity}

A second common argument in favor of balanced budgets is fairness to future generations. ${ }^{33}$ Proponents of this view argue that, "We should consider

30. See, e.g., 1995 House Hearings, supra note 2, at 237 (statement of the National Association of Manufacturers) (asserting that federal government already has too much debt); 1995 Joint Hearings, supra note 2, Part I, at 10 (statement of Rep. Barton) (same); id., Part II, at 76 (statement of Rep. Mack) (same); 1994 Senate Judiciary Comm. Hearings, supra note 2, at 15 (statement of Fred Bergsten, Director, Institute for International Economics) (same); 1983-84 Senate Hearings, supra note 2, at 295 (statement of David A. Stockman, Director of the Office of Management and Budget) (same); 1979-80 House Hearings, supra note 2, at 354 (statement of Rep. Coleman) (same); id. at 426 (statement of Rep. de la Garza) (same); H.R. REP. No. 104-3, at 4, 26 (same); S. REP. No. 102-103, at 13 (1991) (statement of Sen. Biden) (same); S. REP. No. 99-163, at 85 (1985) (statement of Sen. Simon) (same); S. REP. No. 98-628, at 3, 8 (1984) (same). Some argue that the key issue is the size of the current deficit compared to the size of the economy. See, e.g., Rodino, supra note 6, at 794. By this measure, the United States government is financially the healthiest in the industrialized world. See, e.g., Jackie Calmes, Budget Deficit Shrinks to Lowest Level in Two Decades, A Boon for Clinton, WALL ST. J., Oct. 29, 1996, at A2 (noting lowest U.S. deficit as percentage of GDP in two decades). Others argue that even if the deficit is small, a large annual interest obligation imposes a deadweight loss on the economy. See OTTO ECKSTEIN, PUBLIC FINANCE 93 (3d ed. 1973) (describing restrictive effect of financing deficits).

31. See, e.g., 1995 House Hearings, supra note 2, at 137 (statement of Rep. Archer) (asserting that amendment is needed to avoid institutional problems); id. at $240-46$ (statement of James D. Davidson, Chairman, National Taxpayers Union) (same); 1995 Joint Hearings, supra note 2, Part I, at 100, 105 (statement of Gov. George Allen) (same); 1994 Senate Judiciary Comm. Hearings, supra note 2, at 18 (statement of Fred Bergsten, Director, Institute for International Economics) (same); id. at 32 (statement of David M. Stanley, President, National Taxpayers Union) (same); S. REP. No. 104-5, at 3 (same); id. at 70 (statement of Sen. Heflin) (same); S. REP. No. 97-151, at 32-33 (1981) (same).

32. For example, Senator Paul Simon, a leading Democratic advocate of a federal balanced budget amendment, has argued: "Huge, continual deficits strangle the ability of even a nation as rich as ours to respond when emergencies arise or when new opportunities or problems emerge, including recession. With our government deep in debt and continuing to run huge deficits, we remain unable to shoulder new responsibilities." 141 CONG. REC. $\$ 9934$ (daily ed. July 13, 1995); see also 1994 Senate Judiciary Comm. Hearings, supra note 2, at 11 (statement of former Sen. Tsongas) (asserting that balanced budget is necessary for strong federal government); id. at 19-20 (statement of Fred Bergsten, Director, Institute for International Economics) (same); S. REP. No. 104-5, at 3 (same); id. at 70 (statement of Sen. Heflin) (same); S. REP. No. 99-163, at 85 (1985) (statement of Sen. Simon) (same).

33. This is the principal rationale cited by the 1995 Committee Report. See S. REP. No. 104-5, at 2; see also 1995 House Hearings, supra note 2, at 215 (statement of Rep. de la Garza) (asserting that balanced 
ourselves unauthorized to saddle posterity with our debts, and morally bound to pay them ourselves." 34 I will refer to the value underlying such arguments as one of "intergenerational equity."

Debt permits us to shift the costs of current consumption to future generations, just as savings permit us to forgo current consumption for the benefit of future generations. ${ }^{35}$ Many believe that such behaviors have normative implications. ${ }^{36}$ We tend to think well of parents who save to provide for their children. If children were liable for their parents' debts, we would probably think poorly of parents who unnecessarily consumed more than they earned, knowing that their children would be saddled with the resulting obligations. The same normative concerns underlie the intergenerational equity rationale for balanced national budgets. They suggest that each generation should pay for what it consumes.

This may not be just a normative principle. It may also be a precondition for effective democratic decisionmaking. One of the principal functions of government is to supply what economists sometimes call "public goods," goods which society wants but which, because of their nature, markets cannot

budget needed for sake of future generations): 1995 Jom Hearmgs, supra note 2. Pan I. al 3 (statement of Sen. Mack) (same); id., at 10 (statement of Sen. Kyl) (same): id., at 20 (statement of Rep Eu ing) (same); id., at 47-48 (statement of Rep. Manzullo) (same): id.. Pan II. al 67 (statement of Rep Roth) (same); id., Part I, at 87 (statement of William A. Nishanen. Chasman. Cato Instutute) (samne). 1994 Senate Judician Comm. Hearings, supra note 2. at 7.8 (statement of former Sen Tsongas) (same). id at 58 (statement of Sen. Thumnond) (same); id. at 75-76 (statement of Professor Steuart E Sterh) (same), ud at 94 (statement of Paul Volcker, former Charman. Federal Resene Board) (same), 1983-54 Senate Hearings, supra note 2, at 96 (statement of Lewis K. Uhler. President. National Tax Lumitation Comm ) (same); 1979-80 House Hearings, supra note 2. at 314, 315 (stutement of Rep White) (same), H R Rt:-P No. 104-3, at 4, 5 (1995) ("The major impetus for the . . amendment is the rapully mountung federal debi and the impact of climbing interest payments on future generations of Amencans. Future generations that will bear the greatest costs of excessive spending are not formally represented in the political process-and . . need special protections."): S. REP. No. 103-163. at 1-2 (1993) (same). S REP No 102. 103, at 16 (1991) (statement of Sen. Thurmond) (same); S. REP. No. 101-391. at 2 (1990) (same), S REP No. 99-163, at 87 (1985) (statement of Sen. Simon) (same): Biden. supra note 10. al 13A (asserting that deficits limit future options for our children's generation): DeWine, supra note 17, at 11A ("If we don't act now, our children and grandehildren will face an extremely bleak future."): Dole, supra note 10, at $\lambda 21$ (enacting balanced budget amendment is "protecting the fulure for our children and grandehildren"), Steve Largent, Opinion, Balanced Budget Amendment's Impartant. TLLSA WORLD. Mar. 12. 1995. at 2 (declanng that it is not "right for the federal government to spend more than they have and pass the cost off to the next generation"); Safire, supra note 5, at 4 ("[Our children's] tax dollars will be consumed by paying interest on the deficits we run today, leaving nothing for their oun good life They wll condemn their parents' current profigacy as cruelly reckless.").

34. S. REP. No. 104-5, at 2 (quoting Thomas Jefferson).

35. Not all debt is incurred to finance current consumpuon. As President. Thomas Jefferson. a uidely cited advocate of balanced budgets, see Letter from Thomas Jefferson to John Wayles Eppes (June 24. 1813), reprinted in THOMAS JEFFERSON: WRITINGS 1280, 1280-81 (Vihing Press 1984), incurred a debt-like obligation twice the size of the national budget to finance the purchase of the Loutsiana Temton from France. See infra note 87. In modern terms, Jefferson might have justufied this apparent inconsistency b) pointing out that the Territory had an extended useful life and therefore did not, in the masn, constitute current consumption.

36. See supra notes $33-34$. 
efficiently supply-national defense, clean air, safe streets, a well-educated populace, or acceptable patterns of income distribution. ${ }^{37}$ Voters, through government, buy public goods and pay for them with taxes. Like all consumers, when they perceive that they are not getting their money's worth, they vote to buy less. ${ }^{38}$ When they perceive that further purchases would be worth additional taxes, they vote to buy more.

Both the availability of debt to finance current consumption and the need to service debt incurred to finance past consumption may distort this dynamic. An electorate allowed to borrow to consume public goods may consume more than it would be willing to pay for. ${ }^{39}$ Conversely, when a government's budget includes large amounts of debt service for past consumption, voters may perceive that they are getting less than they are paying for. They may react by voting to buy less than they would be willing to buy in a public market not distorted by such constraints. Economists disagree about the extent to which a democracy is capable of choosing optimal levels for the purchase of public goods. ${ }^{40}$ In any case, debt and debt service may distort democratic decisionmaking.

Normative and perhaps efficiency concerns support the principle that each generation be asked to pay currently for its consumption of public goods. As will be discussed below, this principle leads to a target definition different in many regards from that used in the 1995-96 Senate Draft. In particular, it requires that we take spending into account as the purchased items are consumed, not when payment is made. This precludes the use of pure cash flow accounting; it requires instead some form of accrual accounting.

37. See ECKSTEIN, supra note 30, at 8-10 (describing collective [public] goods and noting divergence between private and social costs or benefits); RICHARD A. MUSGRAVE, THE THEORY OF PUBLIC FINANCE: A Study In PUBlic ECONOMY 43-44 (1959) (defining public goods); Peter O. Steiner, Public Expenditure Budgeting, in The ECONOMICS OF PUBlic Finance 241 (Alan S. Blinder et al. eds., 1974) (same).

38. In general, of course, U.S. voters express their preferences by voting for representatives. In recent years, however, the major parties have come to represent different views on public goods, with Democrats stereotypically supporting more expenditures on such goods and Republicans stercotypically supporting less. except on national defense. Voters thus are able to express their views on the purchase of public goods in congressional and presidential elections.

39. An individual debtor is forced to weigh current consumption against his or her own future consumption. If the debtor's personal discount rate exceeds the cost of money, he or she will borrow. Such borrowing is economically efficient. The same is not true of electoral decisions to borrow, since the electorate that votes to borrow is not necessarily the same electorate that has to repay the debt. An electoral decision to borrow is therefore a decision, in part, to shift costs to someone else. This suggests that electoral decisions will not necessarily aggregate correctly the electorate's individual discount rates. Indeed. an electorate may behave like an individual who does not care about the future. An excellent introduction to the problem of intergenerational discounting appears in Daniel A. Farber \& Paul A. Hemmersbaugh, The Shadow of the Future: Discount Rates, Later Generations, and the Environment, 46 VAND. L. REV. 267 (1993).

40. See, e.g., William R. KeECh, ECONOMIC Polttics: The COSTS OF DemoCraCy (1995) (analyzing impact of democratic institutions on economic performance); JOSEPH E. STIGLITZ, ECONOMICS OP THIE PUBLIC SECTOR 148-63 (2d ed. 1988) (discussing economic inefficiencies of majority voting). 


\section{Economic Prudence}

Finally, proponents of balanced budgets argue that government borrowing reduces the national savings rate and crowds private borrowers out of the credit markets. ${ }^{41}$ This has the effect of raising interest rates faced by private borrowers, which reduces private investment and lowers the rate of growth of the economy. As a result, everyone is poorer in the long run. If the Federal Reserve System attempts to keep interest rates down, the argument continues, the stimulative effects of deficit spending will trigger inflation. In short, government deficits are bad for the economy. ${ }^{42}$ I will refer to the value underlying such arguments as "economic prudence."

Again, this value has important implications for target definition. First, it implies that some government borrowing-which is to say, deficit spending-is good. If government proposes to purchase public goods with a higher projected rate of return than competing potential private investments, borrowing to fund such government spending should be encouraged. Any other result would be economically suboptimal. This conclusion, however, can be accommodated in a formulaic balanced budget test only through accrual accounting rules; the cash method will not suffice. Second, borrowing by any government-created entity, not merely the United States itself, may crowd out private investment. This supports a broad definition of entities to which the amendment should apply. Third, if we care about economic prudence, our target definition should accommodate issues of fiscal policy. That is, our target should be defined in terms of or through processes that take economic conditions into account. Fourth, because economics is an evolving and specialized science, the rationale strongly suggests that any balanced budget amendment should permit evolution of the target definition to incorporate new learning and permit the correction of errors. It also suggests that the process of target definition should be entrusted to a body competent to deal with technical economic issues.

41. See, e.g., S. REP. NO. 104-5, at 7 (1995) ("By consumıng such an overwhelming part of the capital in the economy, the Government "crowds out' private sector investment. Thus, when govemment spending rises unchecked by fiscal responsibility, it chokes off the primary engines of economic grow th and nsks our long-term security."); WILLIAM A. COX ET AL. A BALANCED BLDGET CONSTTTUTIONAL AUENDUEVT ECONomiC Issues 1-2 (Congressional Research Serv. Dec. 1994) (distnbuted to Congress as par of Info Pack 463B in preparation for consideration of proposals for balanced budget amendment by 104 th Congress) (noting that deficits reduce investment and produc(uvity): see also HEviviNG ET AL. supra note 11, at 525-27 (describing effects of availability of credit): McCracken, supra note 17. al 6 (descnbing decline in capital formation, leading to decline in productuvity growth)

42. See S. REP. No. 104-5, at 6 (stating that "persistent deficits threaten the Natson's long-tem prosperity"). 


\section{Reconciling Competing Values}

The foregoing values have different implications for defining the budgetary target. To protect all of these values, a balanced budget amendment must create a mechanism through which these sometimes inconsistent implications can be reconciled. In general, to protect intergenerational equity, budgetary balance should be measured by reference to consumption, not cash flows. To reflect economic prudence, budgetary balance should be required, in effect, each business cycle, not each fiscal year, and the microeconomic effects of the test structure should be considered. ${ }^{43}$ Finally, to further institutional responsibility, the target should be a surplus, not merely a balanced budget, whenever it is determined that existing debt levels are unhealthy.

An amendment that fails to make one or more of these adjustments to its budgetary target definition will fail to protect the values discussed above. The optimal reconciliation of these sometimes inconsistent values, however, is likely to vary from time to time. In a depression or period of high inflation, issues of economic prudence will likely predominate. In periods of economic health, surpluses may be warranted to reduce overall debt levels. From time to time, although accrual accounting generally may be required to protect intergenerational equity, economic prudence or institutional responsibility may require explicit consideration of cash flows. Who should make this reconciliation? Congress? The President? The Supreme Court? Some other body $?^{44}$ For the moment, it is sufficient to note an inevitable and profound tension: No static target definition can protect all of the values a balanced budget amendment is supposed to protect, but dynamic target definition is impossible to incorporate in any simple numerical test.

\section{B. Why a Constitutional Amendment?}

One might hope that a review of the principal arguments in favor of a constitutional, rather than a legislative, approach would provide similar insight into the kind of enforcement mechanisms a balanced budget amendment should contain. Unfortunately, the resulting insight is modest at best. This may be because the theoretical explanations for legislative failure are newer and less fully elaborated than the arguments in favor of budgetary balance discussed in the preceding Section.

43. There are many possible ways to accommodate business cycle concerns. One would be to impose multiyear limits; another would be to authorize an independent expert body to set annual or more frequent budgetary targets, taking into account the state of the economy. Such a body also could take the microeconomic effects of test structure into account. See generally infra Section III.A (analyzing who should evaluate targets).

44. For a consideration of these procedural issues, see infra Part III. 
Proponents appear united in their belief that the legislative solution does not work. ${ }^{45}$ Indeed, twelve years after enactment of the Gramm-RudmanHollings Act - which required a balanced budget by 1991 - the federal budget is still in deficit. ${ }^{46}$ But even if we agree that legislation cannot solve the problem, we still are left with the question: Why? If we cannot identify the causes of legislative failure, our efforts to draft an amendment to prevent it may be less than fully successful.

Underlying patterns of congressional behavior are difficult to explain. For almost 200 years, the federal budget was generally in surplus except during periods of war, most notably the Civil War and the World Wars." It was not until the middle of the Vietnam conflict that annual deficits in excess of one percent of gross domestic product (GDP) became the rule rather than the exception. ${ }^{48}$ The deficit mushroomed to $3.5 \%$ of GDP in fiscal year 1975 . declined to $2.7 \%$ of GDP in 1981 , but increased again after the 1981 tax cuts, reaching $6.3 \%$ of GDP in $1983 . .^{49}$ It has declined in each of the last four years, and now stands at $1.4 \%$ of GDP, the lowest level since $1974 .^{50}$ Any fully persuasive theory must explain at least the broad outlines of this history - what procedural or other failures led to apparent changes in behavior in 1967,1975 , and 1981 , and why the government seems to have recently recovered its financial bearings.

Public choice theory, ${ }^{51}$ which treats legislation as a commodity and the

45. See sources cited supra note 33; see also SATURNo. stupra note 2, at 7 ("Without [the] disciplıne [of a constitutional amendment, proponents] believe the goal of a balanced budget would not be altaned because of the conflicting pressure to spend."): S. REP. No. 104-5. at 7 (statung that because legislation has not worked, "[w]e need a constitutional requirement to balance our budget").

46. See Congressional Budget Office. The EcoNomic aNd BIDGet Ot'tlook fiscal Years 1997-2006, at 69-95 (1996) (listing projections through 2050 and concluding that economy will not be able to support debt level); OfFICE OF THE PRESIDENT, Historical TABLES: BLDGet of TIE U ITIED STATES GOVERNMENT 15 (1996).

47. See Department of Commerce, historical Statistics of tie latted States. Colovial TIMES TO 1970, PART 2, at 1104 (1989): OFFICE OF TIE PRESIDENT, supra nole 46. at 15

48. See OfFICE OF THE PRESIDENT, supra note 46, al 21 .

49. See id.

50. See Calmes, supra note 30 , at A2.

51. See, e.g., 1995 House Hearings, supra note 2, at 26, 33 (statement of Rep. Schaefer) (staung that amendment is needed to protect future generations): id. at 88 (statement of Willam P Bart. formet Attorney General) (same); 1994 Senate Judician. Comm. Hearngs. supra note 2, at 75. 76 (statement of Professor Stewart E. Sterk) (same); 1984 Joint Hearing. supra note 2, at 16. 18 (statement of Manuel Johnson, Assistant Secretary for Economic Policy) (statung that amendment is needed to protect diffuse taxpayer interests); id. at 57, 63 (statement of David L. Keatung. Execuluve Vice President. National Taxpayers Union) (same); 1983-84 Senare Hearings, supra nole 2. at 211. 219 (Appendix. Paper Prepared for Taxpayers' Foundation) (same); id. at 295, 300 (statement of David A. Stockman. Director of the Office of Management and Budget) (same); 1979-80 House Hearmgs. supra note 2. at 64, 66 (stalement of James Dale Davidson, Chairman, National Taxpayers Union) (same); id. at 122, 123 (statcment of Mlilton Friedman, Senior Research Fellow, Hoover Institution) (same); id. at $\$ 73.475$ (statement of Alice Rivlın. Director, Congressional Budget Office) (same): S. REP. No. 97-151. at +5 (1981) ("IThe concentrated benefit-dispersed cost' phenomenon] describes the fact that the benefits of any given spending program normally are concentrated within a relatively small class of beneficianes, while the costs of such a program are dispersed throughout a relatively large class of persons, 1.e., the taxpayers."): Bow en, supra note 6, at 570 (suggesting that deficits might be caused by rent-seeking behavior by legislatures): Charies L. Schultze. The Balanced Budget Amendment: Needed? Effectue? Efficienl". 48 NAT"L TAX J. 317. 318 (1995) "The 
legislative process as a market, offers what is perhaps the most academically fashionable explanation of why current processes do not produce balanced budgets. ${ }^{52}$ Legislators are assumed to be motivated by self-interest, not public interest. In the political market, legislation with a broad but diffuse benefit is subject to the classic "free rider" problem of public goods: If a benefit can be enjoyed even by those who do not contribute towards its purchase, less of that good will be purchased than is optimal. This, in turn, leads to more specialinterest legislation and less legislation with a broad but diffuse benefit than would otherwise be the case. For this reason, tax cuts and spending programs are established and protected, but the diffuse interest in a balanced budget loses out. To correct this market failure, the theory concludes, we should place a constitutional thumb on the legislative scale ${ }^{53}$ or, perhaps, address more directly the problem of legislative incentives. ${ }^{54}$

The problem with this theory, at least at its current stage of development, is its inability to explain much of this country's relevant financial history. If the public choice explanation is correct, our government should have run peacetime deficits throughout the nineteenth century and the first half of the twentieth - which it did not-and should not now be moving towards

theoretical rationale for a balanced budget amendment stems from the proposition that majoritarian decision-making rules ... impart a systematic bias towards excessive federal spending and/or deficit financing.").

52. For an introduction to the current public choice debate, see, e.g., DANIEL A. FARBER \& PHILIP P. FRICKEY, LAW AND PUBLIC CHOICE (1991) (professing skepticism of public choice as grand theory, but viewing it as incrementally useful); Daniel A. Farber \& Philip P. Frickey, The Jurisprudence of Public Choice, 65 TEX. L. REV. 873 (1987) (providing critical overview of public choice literature and its implications for public law and noting strong empirical evidence that legislators do care about public interest and act accordingly); Michael E. DeBow \& Dwight R. Lee, Understanding (and Misunderstanding) Public Choice: A Response to Farber and Frickey, 66 TEx. L. REv. 993 (1988) (defending public choice against criticisms of Farber \& Frickey); Daniel A. Farber \& Philip P. Frickey, Integrating Public Choice and Public Law: A Reply to DeBow and Lee, 66 TEx. L. Rev. 1013 (1988) (responding to DeBow \& Lee criticisms); see also Dorothy A. Brown, The Invisibility Factor: The Limits of Public Choice Theory and Public Institutions, 74 WASH. U. L.Q. 179 (1996) (asserting that public choice underestimates ability of majority to infuence political process and is therefore of limited use as predictive tool); Bernard Grofman, Public Choice, Civil Republicanism, and American Politics: Perspectives of a "Reasonable Choice" Modeler, 71 TEX. L. REV. 1541, 1544 (1993) (attempting "to debunk certain widely held beliefs about what Public Choice theory tells us about the practice of democratic politics"); Herbert Hovenkamp, Legislation, Well-Being, and Public Choice, 57 U. CHI. L. REV. 63, 88 (1990) (concluding that public choice theory is attractive but unsupported by empirical evidence); Mark Kelman, On Democracy-Bashing: A Skeptical Look at the Theoretical and "Empirical" Practice of the Public Choice Movement, 74 VA. L. REV. 199 (1988) (providing critical legal studies critique of public choice); Dwight R. Lee, Politics, ldeology, and the Power of Public Choice, 74 VA. L. REv. 191 (1988) (noting that public choicc suggests that idcology will be more important than economic interest in providing general direction to legislation, but less important in determining details); Abner J. Mikva, Foreword, 74 VA. L. REv. 167 (1988) (asserting in foreword to Symposium on Theory of Public Choice that public choice model inadequately explains how government works).

53. See James M. Buchanan, Clarifying Confision About the Balanced Budget Amendment, 48 NAT'L TAX J. 347, 351 (1995) (asserting that only procedural corrections are appropriate).

54. See, e.g., James Dale Davidson, The Balanced Budget Amendment: A Truly Marginal Reform, in BeYond THE STATUS QUO: POliCY PROPOSALS For AMERICA 13, 27 (David Boaz \& Edward H. Crane eds., 1985) ("The only way fiscal order can be restored is by constitutional reform that changes incentives at the margin, raising the costs to congressmen of spending and borrowing money."). 
budgetary balance. 55 Similarly, the theory does not account very well for specific legislative outcomes, such as the Tax Reform Act of 1986, ${ }^{\text {s6 }}$ in which numerous special-interest tax benefits were eliminated to fund a broad but diffuse rate cut. ${ }^{57}$ Nor does it explain why a majority of the members of Congress seem persistently interested in a balanced budget amendment.ss Unless and until the theory is empirically validated, its utility in shaping the structure of balanced budget enforcement mechanisms is likely to be limited.

A second possible explanation is that governments now run deficits in part because of changing economic theories about debt and deficits. Until the Great Depression, the conventional view was that debt and deficits were bad per se. ${ }^{59}$ Keynesianism and the postwar development of a debt-financed consumer economy challenged that view. ${ }^{60}$ Although Keynesianism has itself recently fallen into some disfavor, ${ }^{61}$ this history of changing attitudes may nevertheless explain, at least in par, why chronic deficits are a uniquely

55. James Buchanan, one of the leading exponents of this explanation, argues that the reason politicians exhibited fiscal responsibility until recently was that "IpJolıticians pnor to World War Il would have considered it to be immoral (to be a sin) to spend more than they were willing to generate in tax revenues." Buchanan, supra note 53, at 347 . Keynesianism then eroded this moral constraunt As a result. "[t]he natural proclivities of democratically elected and constıtuency respondent polıticians to spend and not to tax were allowed free play." Id. at 348. While facially plausible, this argument begs the fundamental question: If supermajorities are now persuaded again that deficits are immoral, why do we need a constitutional amendment? Should we not expect political behavior to retum to pre-Kejnesian patterns on its own?

56. Pub. L. No. 99-514, 100 Stat. 2085 (1986).

57. See, e.g., Sheldon D. Pollack, A New Dynamics of Tax Policy, 12 AM. J. TAx POL'Y 61.68 (1995) (noting that "the crude interest group model. so popular among both law school faculty members and joumalists, fails to account for the kind of decisionmaking that charactenzed ax polteymaking in the 1980s"); Daniel Shaviro, Beyond Public Choice and Public Interest: A Studs of the Legislutive Process as Illustrated by Tax Legislation in the 1980s, 139 U. PA. L. REV 1, 6-7 (1990) (assenting that public chuter does not explain 1986 Tax Act).

58. Public choice theory suggests that any congressionally drafted and approved constitutional amendment to balance the budget would be drafted so as to be ineffectuve Drs Thaler and Shefnn offer a more benign explanation for Congress's seemingly inconsistent behavior. Their "economic theory of selfcontrol" asserts that individuals have two separate economic decistonmaking personas. One is a myopic consumer; the other is a long-term planner. The individual concludes. If the costs of montonng and persuasion are high, that the only way to constrain the consumer is for the planner to adopt rules that the consumer cannot easily circumvent. See Richard H. Thaler \& H.M. Shefnn. An Economic Theorv of SelfControl, 89 J. POL. ECON. 392 (1981). This may describe why Congress might simultaneously engage in deficit spending and seek adoption of a balanced budget constitutional amendment to prohibit its own behavior. See COX ET AL., supra note 4l, at 6-7 (using theory of self-control to suggest why Congress might voluntarily impose limitations on its own decisionmaking power). The same rationale might apply to voters as well.

59. See, e.g., S. REP. No. 99-163, at 21-24 (1985) (describing histony of U.S. altutudes towards public debt through 1900s).

60. See, e.g., id. at 24-27 (describing history of deficits as instrument of fiscal policy) See generally

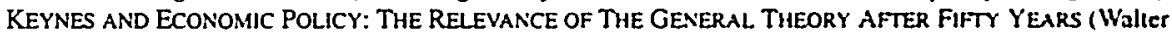
Eltis \& Peter Sinclair eds., 1988) (providing history and current vews of Keynes's theones)

61. See, e.g., Walter Eltis, The Continuing Relesance of Keynes 10 Economic Polior. in KEYves AND ECONOMIC POLICY, supra note 60, at 451, 462 ("The scope for Keynesian fiscal reflation may therefore be limited to taking advantage of a small stable cyclically corrected deficit as an element in policies to reduce unemployment in periods of recession ... : a tolerance of such deficits was really all that Keynes himself actually recommended ...."); Bennett T. McCallum. The Role of Demand Banagement in the Maintenance of Full Employment, in KEYNES AND ECONOMIC POLICY. supra nole 60, at 25 (revicwing continued viability of Keynesian activism). 
modern phenomenon and, indeed, why the pendulum may currently be swinging back in favor of balanced budgets. But if economic theory sanctioned modern deficits and a further change in theory now causes Congress to seek to alter its course, the political process is not broken at all; Congress is merely applying prevailing theories of political economy to public policy, as it should. Some amount of political turmoil may be expected in the transition, but if this explanation is correct, there is no need for a constitutional amendment.

A final possible explanation has its origins in the mundane traditions of descriptive political science. Until the Great Depression, the role of the federal government was relatively limited. ${ }^{62}$ Meanwhile, the government derived a substantial portion of federal revenue from import tariffs, which were designed to protect domestic industry. ${ }^{63}$ As a result, public sentiment often favored higher federal taxes, sometimes much higher than were necessary to fund the government's activities. ${ }^{64}$ Deficits were generally not the problem; surpluses sometimes were. ${ }^{65}$ Beginning in the 1930s, changes in both spending and revenue altered this dynamic. The emergence of the United States as a world power required maintenance of higher levels of military spending. ${ }^{66} \mathrm{~A}$ confluence of factors-probably including the horror of the Great Depression, a perceived need to compete against communism, and the emergence of an electorate with a stronger national identity-created political demand for expanded social spending at the federal level. ${ }^{67}$ Meanwhile, protectionism fell into disfavor and the government began to rely primarily on the income tax, which did not have a built-in constituency for higher rates. ${ }^{68}$ As the electorate demanded more spending and lower taxes, the explanation concludes, a powerful political base was created for deficit spending.

62. See, e.g., DEPARTMENT OF COMMERCE, supra note 47, at 1123-24 (listing federal government expenditures, by function, from 1902 to 1970). Until the 1930s, it appears that the bulk of the federal budget was dedicated to defense and veterans' services, the postal service, general administration, interest on the national debt, and ports. See id.

63. See id. at 1106-07 (listing federal government receipts from 1789 to 1939 and internal revente collections from 1863 to 1970).

64. See Davis Rich Dewey, Financial history of THE UNited States 172-96 (12th ed. 1936) (describing political struggles regarding import tariffs).

65. During the 1830 s, for example, high tariffs generated more than enough revenue to fund existing federal expenditures and significant opposition existed to expanded federal spending. The resulting surplus became a political problem, which Congress solved through distributions to the states. Although technically loans, the states treated these distributions as gifts and apparently made no effort to repay them. See MARgaret G. Myers, A FinANCIAL History OF THE UNITEd STATES 94-96 (1970) (describing distribution of surpluses).

66. See DEPARTMENT OF COMMERCE, supra note 47, at 1123-24 (noting federal government expenditures, by function, from 1902 to 1970 and documenting major increase in military spending during World War II that persisted into 1950s and 1960s).

67. See, e.g., Rodino, supra note 6, at 794. The expansion and recent contraction of the federal role is explored in THE RISE AND FALL OF THE NEw DEAL ORDER, 1930-1980 (Steve Fraser \& Gary Gerstle eds., 1989).

68. See DEPARTMENT OF COMMERCE, supra note 47, at $1105-06$ (listing federal government receipts by source 1940 to 1970 and federal government receipts in administrative budget 1789 to 1939). 
Unlike public choice theory, this more traditional explanation does not postulate any market failure. Congress is simply giving the electorate what it wants; the problem is inherent in democracy; democracy is not always institutionally responsible; it is not always fair to future generations; it is not always economically prudent. We need a balanced budget amendment, this explanation suggests, to protect the sovereign People from themselves. If we accept this explanation, it follows that enforcement of a balanced budget amendment cannot be entrusted to Congress or the President, who are, after all, expected to reflect the popular will.

In sum, arguments in favor of a balanced budget amendment to the U.S. Constitution provide only modest and conflicting guidance as to what such an amendment should look like, suggesting alternatively that enforcement mechanisms not under congressional or presidential control may be necessary, that procedural corrections may be warranted, that it may be useful to address legislative incentives directly, or perhaps even that no amendment is necessary at all. In the absence of clearer guidance, we are left with the task of balancing our desire for credible and effective enforcement against our desire not to disrupt an otherwise successful constitutional system.

\section{Other Normative Issues}

In drafting a balanced budget amendment, at least four other issues must be resolved: the extent to which it should be enforceable if the political branches fail to comply voluntarily; how flexible it should be in its application; whether it should seek to accomplish goals other than balancing the budget; and the extent to which disruption of existing constitutional structures, rules, and doctrines is acceptable. Each of these issues has significant implications for technical structure. My technical analysis will reflect my own views on these questions. Specifically, I posit that a well-drafted amendment should meet at least four criteria: (1) it should be enforceable, in spirit as well as in letter; (2) it should permit flexibility in at least three regards-to allow improvements to the budget process itself, to accommodate fiscal policy concerns, and to permit the United States to meet extraordinary challenges and opportunities; (3) it should be politically neutral-that is, it should not change or distort political decisionmaking, intentionally or inadvertently, except to require a balanced budget; and (4) it should not disrupt the balance of powers among the several branches or otherwise disrupt our existing constitutional system more than absolutely necessary. 


\section{Enforceability}

Some have argued that a balanced budget amendment need not be enforceable, that a statement of principles will suffice. ${ }^{69}$ The committee report accompanying the 1995-96 Senate Draft, for example, argues that the "ultimate enforcement mechanism" will be the political process. ${ }^{70}$ By raising the visibility of the issue, the amendment is apparently expected to cause Congress to comply voluntarily or to cause voters to unseat politicians who cut taxes or raise spending and thereby increase the deficit.

Such arguments are unpersuasive. The Gramm-Rudman-Hollings $\mathrm{Act}^{71}$ was highly visible. It is still the law, in theory, although it is now viewed by many as a dead letter. ${ }^{72}$ State legislatures have similarly ignored or attempted to circumvent state balanced budget constitutional provisions. ${ }^{73}$ In the long run, there is no reason to believe that an unenforceable federal balanced budget amendment would fare any better. Acceding to arguments that a balanced budget amendment need not be enforceable would undermine both that amendment and the Constitution as a whole. ${ }^{74}$ By this, I do not mean that courts, the traditional guarantors of constitutional order, should necessarily play any significant role in enforcement. I mean, rather, that the institutional dynamics contemplated by the amendment reasonably should be expected to lead to routine compliance with defined budgetary targets notwithstanding political pressures to the contrary. A mere statement of principles will not suffice.

At least as important, but far less widely discussed, is the premise that the amendment's enforcement mechanisms should protect its spirit, not merely its letter. Almost any numerical test can be circumvented in spirit, even if subject to strict literal enforcement. Here, the state experience is instructive. ${ }^{75}$

69. See, e.g., 128 CONG. REC. 15,810-12 (1982) (statement of Sen. Thurmond) (asserting that purpose is to establish balanced federal budget as "norm"); Buchanan, supra note 53, at 354 ("The very fact that such a rule would be constitutional, and understood as such, would seem to be sufficient to guarantee adherence."). But see 1995 House Hearings, supra note 2, at 14, 17 (statement of Charles L. Schultz, Senior Fellow, Brookings Institution) (asserting that balanced budget amendment should be enforceable); id. at 26, 39 (statement of Rep. Schaefer) (same); id. at 67 (statement of William P. Barr, Former Attorney General, Department of Justice) (same); S. REP. No. 104-5, at 9-Il (1995) (same); H.R. REP. No. 104-3, at 4, 6-8 (1995) (same); S. REP. No. 97-151, at 62-66 (1981) (same).

70. S. REP. No. 104-5, at 9.

71. Balanced Budget and Emergency Deficit Control Act of 1985, Pub. L. No. 99-177, 99 Stat. 1038, as amended by Balanced Budget and Emergency Deficit Reduction Reaffirmation Act of 1987, Pub. L. No. 100-119, 101 Stat. 754.

72. See supra note 10.

73. See supra note 11 .

74. See THE FEDERALIST No. 80, at 516 (Alexander Hamitton) (Edward Mead Earle ed., 1937) ("[T]here ought always to be a constitutional method of giving efficacy to constitutional provisions.").

75. See, e.g., Kenneth J. Kirkland, "Creative Accounting" and Short-Term Debt: State Responses to the Deficit Threat, 36 NAT'L TAX J. 395 (1983) (outlining some techniques used to circumvent state balanced budget and debt limitation provisions); Daniel B. Suits \& Ronald C. Fisher, A Balanced Budget Constitutional Amendment: Economic Complexities and Uncertainties, 38 NAT'L TAX J. 467 (1985) (reviewing Michigan's circumvention experience). 
Summarizing a history of state legislative circumvention of debt limitation provisions, one prominent commentator concluded: "Since $1900 \ldots$ states have developed means of borrowing for public improvements that escape constitutional bans... This development has been so complete that most states are now able to borrow funds in any amount for nearly any purpose. ${ }^{76}$ In 1982, a Congressional Budget Office study concluded that during the preceding twenty years, state debt had risen at a higher rate than federal debt, even though most states were subject to constitutional limitations then being considered at the federal level. ${ }^{77}$

In the face of this experience, amendment proponents can nevertheless assert that states, by and large, balance their budgets. Such assertions are literally true. All that this means, however, is that states nominally comply with whatever numerical tests their constitutions impose. Even if a legislature routinely takes advantage of holes in those tests, running up large debts and spending more than the state takes in, its members can truthfully declare: "We have balanced the budget."

Mere nominal compliance, I suggest, is not an adequate goal. Indeed, nominal compliance with an inadequately specified target might be as damaging in the long run as overt noncompliance. It would provide political cover for financial irresponsibility and might thereby reduce the pressure for real solutions. Before a balanced budget amendment is proposed or ratified, therefore, we should be confident that it will actually do what its supporters in Congress, in the state legislatures, and within the American electorate expect.

\section{Flexibility}

While the values underlying balanced budgets may be important, they are not the only values that we, as a nation, share. From time to time, we may agree that some other goal or value is either more important than or not inconsistent with the amendment's values. A good balanced budget amendment should therefore permit flexibility in the application of numerical tests in at least three regards.

First, it should be drafted in language independent of a particular budget process. This is necessary to give Congress flexibility to change and improve its budgetary procedures over time. Unless we believe that the current process cannot be improved, an amendment that constitutionalizes that process and freezes it forever in its current form would be unnecessarily rigid and, in the end, self-defeating. Further, an amendment that invokes existing budgetary concepts brings with it unnecessary interpretive baggage. For example, future

76. HEINS, supra note 11 , at $\mathrm{v}$.

77. See CONGRESSIONAL BUDGET OFFICE, supra note 2, at 117 
interpreters of a constitutional test defined by reference to "outlays" and "receipts"78 or "debt of the United States"79 might be tempted to turn to the meanings given those terms at the time the amendment was proposed and ratified. Unwarranted fidelity to static definitions would radically limit responses to innovative circumvention techniques.

Second, it should be consistent with sound fiscal policy, what economists sometimes refer to as the stabilization aspect of government taxation and expenditure ${ }^{80}$ Macroeconomic issues arise in several contexts. Perhaps most obvious is the problem of transitions. The economic price of achieving balance in a single year can be prohibitive; sound fiscal policy may require a less abrupt transition to budgetary balance. ${ }^{81}$ This problem may arise when the amendment is first ratified. It will also arise whenever the budget goes out of balance thereafter. For example, if the United States goes to war and runs one or more permitted deficits, an amendment that does not take into account the problem of transitions-the 1995-96 Senate Draft, for example-may require an abrupt and disruptive return to balanced budgets immediately upon the conclusion of that war.

Another macroeconomic concern is the problem of economic downturns. An economic recession or depression may throw the budget out of balance without any fault on Congress's part. ${ }^{82}$ To require an immediate return to budgetary balance could aggravate such a downturn. Some economists believe, for example, that a policy of attempted balanced budgets in the face of a declining economy helped cause the Great Depression. ${ }^{83} \mathrm{~A}$ balanced budget

78. See infra Section II.A.

79. See infra Section II.B.

80. See, e.g., MUSGRAVE, supra note 37, at 22-27; Alan S. Blinder \& Robert M. Solow, Analytical Foundations of Fiscal Policy, in THE Economics of PuBliC FinanCE 3, 4 (1974).

81. See, e.g., S. REP. NO. 104-5, at 29 (1995) (statement of Sen. Biden) (suggesting that glide path is necessary). A proposal to structure a formulary "glide path" to budgetary balance was defeated in the Senate Judiciary Committee and was therefore not included in the 1995-96 Senate Draft. See id. at 12 (noting defeat of glide path amendment).

82. See 1995 House Hearings, supra note 2, at 14 (statement of Charles L. Schultz, Scnior Follow, Brookings Institution) (asserting that recession or depression may throw budget out of balance); $i$ d. at 115 (statement of Alice M. Rivlin, Director, Office of Management and Budget) (same); id. at 168 (statement of Rep. Gephardt) (same); 1995 Joint Hearings, supra note 2, Part I, at 26, 85 (statement of William A. Niskanen, Chairman, Cato Institute) (same); 1979-80 House Hearings, supra note 2, at 148 (statement of Milton Friedman, Senior Research Fellow, Hoover Institution) (same); Buchanan, supra note 53, at 352-53.

83. See, e.g., JoHn A. GARRATY, THE GREAT DEPRESSION 15-19, 47 (1986). There is no consensus as to the causes of the Great Depression. Some have attributed it to mismanagement of the money supply, see, e.g., MILTON FRIEDMAN, A MONETARY HISTORY OF THE UNITED STATES: 1867-1960, at 407-19 (1963), some to the Smoot-Hawley tariff, see, e.g., JUDE WANNISKI, THE WAY THE WORLD WORKS 136 (1983), and some to the lack of an international lender of last resort, see, e.g., CHARLES KINDLEBERGer, THE WORLD IN DEPRESSION 289-90 (rev. ed. enlarged 1986). Proponents of a balanced budget amendment have sometimes taken sides in this debate. In S. REP. No. 99-163, at 21 (1985), for example, the Senate Judiciary Committee asserted: "While there are many economic explanations for the Great Depression, it is extremely difficult to understand the argument of a small minority of individuals that the commitment of the Hoover Administration to a balanced budget was in any way responsible." Such arguments miss the point. The problem is that economics is still an evolving science. The possibility of a second Great Depression, this time in a world with nuclear weapons, is simply unacceptable. Accommodating this concern, moreover, does not require rejection of a balanced budget amendment per se; it merely requires 
amendment that triggers similar future depressions would not be viewed as a success.

A third and related problem arises because the federal budget is believed to have a countercyclical effect. ${ }^{84}$ In a strong economy, the budget tends to produce a surplus, or at least a reduced deficit, which has a moderating effect on the economy. By contrast, in a weak economy, budget deficits are exacerbated because taxable activity declines and spending increases on items such as unemployment compensation. This, in turn, may have an ameliorative effect on recessions. ${ }^{85}$ The result is to moderate both economic extremes. A policy of balanced budgets defined without regard to economic conditions would exaggerate both extremes-making expansions stronger and harder to control, and recessions or depressions more serious. Such a policy would not be economically prudent.

Finally, a good balanced budget amendment should permit the use of debt to meet extraordinary national challenges and opportunities, even as it prohibits the use of debt to finance routine operations. Most of this country's wars have been debt-financed. ${ }^{86}$ The Louisiana Purchase required the federal government to incur a debt-like obligation almost twice the size of its annual budget. ${ }^{57}$

that we design the amendment with sufficient flexibilty to permit intelligent responses to the problem

84. See COX ET AL., supra note 41 , at 15-17.

85. See, e.g., 1995 Joint Hearings, supra note 2. Part 1, at 106 (statement of Lawrence Chmernne, Managing Director and Chief Economist, Economic Stralegy instutule) (assertung that budget defletls can ameliorate recessions); 1995 House Hearmgs. supra note 2. al 111-12 (statement of Alice M Rwlin, Director, Office of Management and Budget) (same): ıd. at 198. 200 (statement of Robert Eisner. Protessor of Economics, Norhwestern University) (same): id. at 234 (statement of Charles J Whalen. Resident Scholar, Jerome Levy Economics Institute) (same); 1979-80 House Hearmgs, supra note 2, at 29 (statcment of Professor Paul A. Samuelson) (same); id. at 101. 103 (statement of Charles L. Sihulize, Chatrman. Council of Economic Advisers) (same); id. app. at 161. 187 (Gerard Brannon. Allen R Ferguson. A Report on the Economic Issues Raised by Proposed Constumional Amendments ro Require a Balanced Budyet) (same); id. at 473-74 (statement of Dr. Alice Rivlin. Director. Congressional Budget Office) (same). ECKSTEIN, supra note 30, at 100-09 (same); HENNING ET AL., supra note 11, at S09-11 (same); PALL A SAMUELSON, ECONOMICS 353-57 (12th ed. 1985) (same): see also id. al S2465 (dally ed Feb 10. 1995) (statement of Sen. Sarbanes, citing Dr. Laura D'Andrea Tyson, Ii's a Recıpe for Economic Chaos. WAsu POST, Feb. 7, 1995, at A19); id. at S2205-06 (daily ed. Feb. 6. 1995) (statement of Sen Boxer. eitung letters of Dr. James Tobin, Dr. Robert M. Solow, Dr. Lawrence R. Kleın, and statement signed by "oter 200 economists and political scientists") (same): $t d$. at S2119-22 (dauly ed Feb 3. 1995) (statements of Henry J. Aaron, Dr. Paul A. Samuelson \& Dr. Roben M. Solow: Dr Jeff Faux. and Dr Luwrence Chimerine, inserted at request of Sen. Moynihan) (same).

86. See DEPARTMENT OF COMMERCE, supra note 47, at 1104-05 (charung administraure budget of federal govemment from 1789 to 1939 and federal government tinances from 1929 to 1970). BRAY HaMmOND, SOVEREIGNTY AND AN EMPTY PURSE: BANKS AND POLITICIANS IN MIE CINIL WAR passim

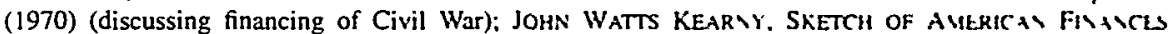
1789-1835, at 76-110 (New York, G.P. Putnam's Sons 1887) (discussing finaneing of War of 1812). MYERS, supra note 65, at 75-78 (same); id. at 148-73 (discussing financing of Cistl War). ul at 270-92 (discussing financing of World War I); id. al 343-60 (discussing financung of World War II). ALEXA DER D. NOYES, THE WAR PERIOD OF AMERICAN FINANCE 1908-1925, at 194-214 (1926) (discussing tinancing

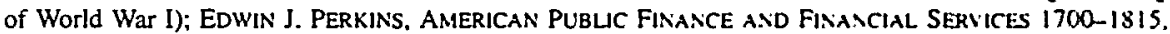
at 324-48 (1994) (discussing financing of War of 1812); ALLEN SCHICK. THE FEDERAL BL DGET POLTICS. POLICY, PROCESS 34 tbl.3-2 (1995) (Impact of War on Federal Spending. Selecied Fiscal Years. 1811-1975).

87. See Act of Nov. 10, 1803, stat. I, ch. II. 2 Stat. 245: Id. at ch. III. 2 Stat. 247: Convention for the Cession of Louisiana: Financial Arrangement, Apr. 30, 1803, U.S.-Fr.. 8 Stat. 206: DEWEY, supra note 64. 
Similarly, the acquisition of Florida was at least nominally financed through an assumption of debt. ${ }^{88}$ We do not know what challenges and opportunities will face us in the next several centuries. ${ }^{89}$ It is safe to predict, however, that any amendment that limits the United States government's ability to deal with extraordinary events will place this nation at a significant disadvantage vis-àvis its competitors and adversaries. ${ }^{90}$

In general, proponents of a balanced budget amendment have acknowledged a need for flexibility but have not always drafted language to accommodate it. ${ }^{91}$ This is both unfortunate and unnecessary. A well-drafted

at 121 (explaining Louisiana's price of $\$ 15,000,000$, financed through issuance of $\$ 11,250,000$ new $6 \%$ stock, redeemable after 15 years in four annual installments, $\$ 2,000,000$ to be paid in cash, and remainder to be met by temporary loan); KEARNY, supra note 86, at 61 (same). The obligation issued was stock, not debt, but had a fixed maturity date and paid a fixed retum indistinguishable from debt. The circumvention potential of stock issuances is discussed below. See infra notes 158-63 and accompanying text.

88. By the Treaty of February 22, 1819, between the United States and Spain, the United States agreed to assume responsibility for up to five million dollars in claims by U.S. citizens against Spain; in exchange, it received Florida. See Treaty of Amity, Settlement, and Limits, Feb. 22, 1819, U.S.-Sp., 18 Stat. (2) 712 , 715 ("The United States, exonerating Spain from all demands in future, on account of the claims of their citizens to which the renunciations herein contained extend . . . undertake to make satisfaction for the same, to an amount not exceeding five millions of dollars."). Compare HUBERT BRUCE FULLER, THE PURCHASE OF FLORIDA: ITS HISTORY AND DIPLOMACY 307 (Rembert W. Patrick ed., Univ. Fla. Press 1964) (1906) (stating that United States received Florida in exchange for agreement to settle up to five million dollars of claims of U.S. citizens against Spain), with id. at xi, xiii (editorial preface by Rembert W. Patrick) (asserting that "[n]ever in American history have the terms of an international agreement been as incorrectly reported and misinterpreted" and noting that "[n]ot a penny was paid to Spain for the Floridas, or to Americans claiming indemnity for property losses suffered by Spanish acts, or to Spaniards demanding payment for American depredations").

89. Futurists generally take current trends and extrapolate forward. See, e.g., DONELLA H. MEADOWS ET AL., THE LIMITS TO GROWTH (1972) (using mathematical models to project population growth, food production, and other trends); ALVIN TOFFLER, FUTURE SHOCK (1970) (projecting social and technological trends). Because the most difficult challenges and opportunities are likely to be those that take us by surprise, prediction is a doubtful proposition. Nevertheless, with this caveat, events that might lead supermajorities to believe that the United States should incur more debt for nonroutine purposes within the next fifty years might include a rapid and widespread proliferation of nuclear weapons, a collapse of tho global environment, or a race for the colonization of space or the moon (which would likely have significant military implications).

90. Any attempt to posit how history would have been different if the original Constitution had contained an absolute and inflexible balanced budget requirement is necessarily speculative. It is fair to say, however, that the United States probably would have been a very different country. Without the Louisiana Purchase and the purchase of Florida, its territory would have been much smaller. The Marshall Plan and NATO would have been less politically feasible, as would involvement in the Korean and Vietnam conflicts. Some other country might have been the first to place a man on the moon. Indeed, it is not even clear that the United States would have been willing to finance the policy of containment-and the arms buildup that was necessary to implement it-that arguably led to the defeat of Communism.

91. See, e.g., S. REP. No. 104-5, at 8 (1995) (noting that 1995-96 Senate Draft has necessary flexibility); see also 1995 House Hearings, supra note 2, at 26, 48 (statement of Rep. Schaefer) (asserting that balanced budget amendment should be flexible); 1994 Senate Judiciary Comm. Hearings, stipra note 2, at 25, 29 (statement of Martin A. Regalia, Vice President and Chief Economist, U.S. Chamber of Commerce) (same); 1984 Joint Hearing, supra note 2, at 20, 25 (statement of Manuel H. Johnson, Assistant Secretary for Economic Policy) (same); id. at 44, 50 (statement of Richard W. Rahn, Vice President and Chief Economist, U.S. Chamber of Commerce) (same); 1983-84 Senase Hearings, supra note 2, at 271, 275 (statement of Richard W. Rahn, Vice President and Chief Economist, U.S. Chamber of Commerce) (same); id. at 295, 304 (statement of David A. Stockman, Director of the Office of Management and Budget) (same); 1979-80 House Hearings, supra note 2, at 336 (statement of Rep. Rousselot) (same); id. at 358-59 (statement of Rep. Quayle) (same); H.R. REP. No. 104-3, at 19 (1995) (same); S. REP. No. 102- 
balanced budget amendment can and should permit flexibility in each of the foregoing regards.

\section{Political Neutrality}

While enforcing the values it is intended to enshrine, a good balanced budget amendment should not otherwise diston political decisionmaking, intentionally or unintentionally. I borrow this concept from tax policy, in which it is often argued that the tax system, while inevitably reducing the after-tax returns from economic activity, should be structured so as otherwise to interfere with market decisions as little as possible. ${ }^{92}$ Similarly, I suggest, a well-drafted balanced budget amendment should not otherwise interfere with the ebb and flow of politics. It should favor neither Republicans nor Democrats, conservatives nor liberals. If Congress, in the absence of such an amendment, would choose Policy A over Policy B, each having the same longterm costs, the amendment should not create incentives to select the less desired policy. An amendment that distorts this process will lead to poorer, less democratic government.

Two types of potential distortion deserve special note. First, a balanced budget amendment should not bias the political process in favor of short-term solutions. It would be ironic indeed if a provision intended to ensure the longterm financial health of the nation were to inhibit the long-term solution of other problems. While this premise may seem obvious, we will discover that it has important implications for our choice of accounting methods."

Second, a well-drafted balanced budget amendment should not attempt to further political goals other than balancing the federal budget. Many draft amendments have included provisions limiting federal taxes or otherwise attempting to constrain federal activities. ${ }^{4}$ Such "antifederalist" provisions,

103, at 14 (1991) (same); S. REP. NO. 99-163, at 78 (1985) (statement of Sen. Biden) (same). S REP No $80-154$, at 2 (1947) (same).

92. For example, the Department of Treasury has defined such neutrality as follous

[An ideal tax system] would not unnecessarily distor choices about hou income is earned and how it is spent. It would not unduly favor leisure over work. or consumption over saving and investment. It would not needlessly cause business firms to modify their production techniques or their decisions on how to finance their activities. A neutral tax policy would not induce businesses to acquire other firms or to be acquired by them merely for tax considerations. It would not discourage risk-taking or the formation of new businesses. It would not discourage competition by granting special preferences only to one industry or one ispe of financial institution. In short, an ideal tax system would be as neutral as posstble toward pnvate decisions.

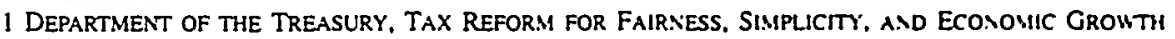
13 (Nov. 1984).

93. See infra Subsection II.A.2.

94. See, e.g., H.R.J. Res. 1, $\S 2,104$ th Cong. (1995) (providing that no bill to inerease revenue shall become law unless approved by $60 \%$ of whole number of each House): S.J. Res. $2 . \$ 2.101$ si Cong. (1989) (providing that receipts shall not increase by rate greater than rate of increase in national income in previous fiscal year unless each House passes bill directed solely to approving specific additional receipts). See generally SATURNO, supra note 2, at 37-40 (analyzing selected tax or expenditure limitation 
I suggest, should not be included in any proposed balanced budget amendment for several reasons.

First, the amendment is most likely to produce balanced budgets in the long run if it commands the broadest possible political support. An amendment that is viewed in part as an attempt by a temporary antifederalist majority to legislate in constitutional stone is more likely to be circumvented and less likely to command continuing popular support when the political winds shift, as they always do.

Second, many members of Congress, state legislatures, and the electorate support the concept of a balanced budget amendment but are less clear in their support of antifederalism. ${ }^{95}$ One suspects that antifederalist provisions have been included in politically popular draft balanced budget amendments in part because such provisions lack the support necessary to make it through the amendment process on their own. ${ }^{96}$ This kind of legislative game-playing is inappropriate in the drafting of constitutional amendments. The power to frame is one of Congress's most potent powers; forcing the nation to choose between a balanced budget amendment with antifederalist provisions and no balanced budget amendment at all is improper. ${ }^{97}$ Even proponents of antifederalism should think twice before endorsing such a precedent. Members of Congress, the state legislatures, and the electorate deserve the opportunity to consider each set of provisions on its own merits.

\section{provisions).}

95. See, e.g., 1995 House Hearings, supra note 2, at 129 (statement of Rep. Frank) (expressing concern about antifederalist provisions of balanced budget amendment proposal); 1994 Senate Judiciary Comm. Hearings, supra note 2, at 1-2 (statement of Sen. Simon) (focusing on budgetary balance); $i d$. at 6-8 (statement of former Sen. Tsongas) (same); id. at 16 (statement of Fred Bergsten, Director, Institute for International Economics) (supporting balanced budget amendment, opposing tax limitation provisions); S. REP. No. 99-163, at 3 (noting that S.J. Res. 225 "does not propose to read any specific level of spending or taxing forever into the Constitution"); Buchanan, supra note 53, at 351 (opposing tax limitation provisions).

96. An amendment to require a supermajority vote to raise taxes recently failed in the House. See John Godfrey, Tax Limitation Constitutional Amendment Falls Short in House, 71 TAX NOTES 430 (1996).

97. Although there is no requirement in Article $V$ that each constitutional amendment address a single subject, members of Congress have expressed concern about draft amendments that combine subject matters, especially in connection with the Twenty-Third Amendment, which originally contained three unrelated provisions, two of which were stripped out before the amendment was proposed and ratified. See 106 CONG. REC. 1520 (statement of Sen. Case) ("Particularly with amendments, it has seemed to me desirable to have them refer to one subject, either dealing with direct election of Senators, women's suffrage, or whatever the subject might be."); id. at 1521 (statement of Sen. Javits) ("I am at a loss to understand why so important a matter as a constitutional amendment ... should not be considered and debated on its own."); id. at 1716 (statement of Sen. Stennis) ("[T]he fact that they are proposed together is enough to defeat both of them."); id. at 1758 (statements of Sens. Keating and Cotton) (noting that cach amendment should be presented and voted upon separately); id. at 12,557 (1960) (statement of Rep. McCulloch) ("[W]ith anything as fundamental and lasting as a constitutional amendment I much prefer to confine consideration to one topic at a time."). For a history of the Twenty-Third Amendment, see STAFF OF SUBCOMM. ON THE CONSTITUTION, SENATE COMM. ON THE JUDICIARY, 99TH CONG., AMENDMENTS TO THE CONSTItUTION: A BRief Legislative History 76-77 (Comm. Print 1985). Although the Bill of Rights was proposed as a single resolution, the states nevertheless considered each provision separatcly and in fact rejected two. See id. at 5-12. 
Third, drafting a technically sound balanced budget amendment is hard enough. A rigorous analysis of proposed tax limitations or similar antifederalist provisions is beyond the scope of this Article. However, before any such provisions are enshrined in the Constitution, they should be subjected to the same kind of technical analysis that this Article proposes for balanced budget provisions. Such an analysis has not yet been undertaken.

Fourth, an antifederalist amendment is theoretically distinct from a balanced budget amendment. ${ }^{98}$ The former requires less governance, regardless of how such governance is paid for; the latter, financially responsible, pay-as-you-go governance, regardless of size or scope. An antifederalist amendment might permit the incurring of debt to finance actions believed to be appropriate at the federal level, such as preparing to meet a military threat. Conversely, it would prohibit federal intrusion into realms believed more appropriate for state action, even where the proposed federal program is fully tax-funded. A balanced budget amendment is at best a poor surrogate for well-drafted antifederalist rules.

\section{Constitutional Nondisruption}

Finally, a well-drafted balanced budget amendment should preserve existing constitutional provisions and doctrines whenever possible. It should not significantly disrupt the current system of checks and balances among the several branches. ${ }^{99}$ To the greatest extent possible, a balanced budget amendment should refrain from tampering with political decisions best left to

98. Many balanced budget proposals have included limitations on Congress's power to tax Although a smaller federal role is currently linked politically with lower taxes, for most of our histon this was not the case. Until World War I, a substantial portion of federal revenues came from taxes on imports See DEPARTMENT OF COMMERCE, supra note 47, at 1106 . Levels of taxation were determined in significant pan by reference to the need of U.S. business for protection. not by the need of the US government for revenue. As a result, the government sometimes faced the percesved problem of repealed budget sumpluses See generally MYERS, supra note 65, at 94-96 (discussing budget surplus dunng Jackson presidency). Should the United States adopt a value added tax refundable at the border. the current alliance between those who support lower taxes and those who support a smaller federal role might disappeas. A refundable value added tax-from which exports are exempt but to which imports are subject in full-has protectionist aspects. As a result, those who represent the interests of Amencan business might tind themselves supporting both smaller government and higher taxes, the histoncal norm. Should this occur, some who have heretofore advocated constraints on taxes to limit federal acuvity would find themselves constraned by their own amendment.

99. See, e.g., Mistretta v. United States. 488 U.S. 361. 381 (1989) (contending that "ithe greaiest security against tyranny ... lies . . in a carefully crafted system of cheched and balanced power withın each Branch"); Bowsher v. Synar, 478 U.S. 714. 722 (1986) (asserting that "chechs and balances were the foundation of a structure of govermment that would protect liberty"): THE FEDERALIST No 47, al 314

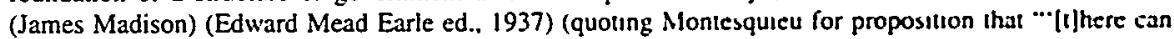
be no liberty where the legislative and executive powers are united in the same person. or body of magistrates"); THE FEDERALIST, NO. 51, at 337-38 (Alexander Hamilion or James Madison) (Edward Mead Earle ed., 1937) ("This policy of supplying. by opposite and rial interests, the defect of better motives ... . cannot be less requisite in the distribution of the supreme powers of the State ") 
the political branches. ${ }^{100}$ Most importantly, it should make clear which existing constitutional rules it changes and which it leaves in place. Silence about issues so close to the heart of the structure of government is both dangerous and unnecessary. In this regard, the 1995-96 Senate Draft, it will be seen, ${ }^{101}$ is disturbingly open-ended.

Readers may disagree with some or all of the foregoing criteria. There is no consensus as to what a balanced budget amendment should look like, nor do I expect this Article to create one. What I do suggest is that all draft balanced budget amendments should be subject to close technical scrutiny at the design stage regardless of the evaluative criteria their authors believe appropriate. This Article will examine the technical issues that arise in attempting to meet the criteria I have urged; a similar analysis should be made of draft amendments purporting to satisfy different criteria.

That said, how can we design and implement a technically sound balanced budget amendment? The problem can be divided into two parts: first, defining a budgetary target, and second, specifying the processes through which that target is interpreted, enforced, and waived. I will consider the issues raised by each of these tasks separately.

\section{DEFINING THE BUdGETARY TARGET}

A balanced budget amendment is typically built around a numerical test in which the relationship between income and spending is compared periodically to a target. In defining that test, the amendment must, explicitly or implicitly, address at least four questions.

(i) What method of accounting should be used? Stated another way, when should spending be taken into account? When Congress authorizes it? When the executive agency signs the contract obligating the government? When the resulting bill is paid or as the purchased item is used? Similarly, when should income be taken into account?

(ii) What entities or programs should be subject to a balanced budget test? Only the United States itself? The United States plus all wholly owned subsidiaries? Perhaps some broader or different class of entities and programs?

(iii) When should the test be applied? When Congress votes? When money is spent? Only when a debt ceiling is reached? ${ }^{102}$ At some other time?

100. See, e.g., S. REP. No. 104-5, at 8 (1995) (claiming that 1995-96 Senate Draft "leaves political decisions to the political system").

101. See infra Subsection III.B.5.

102. Section 2 of the 1995-96 Senate Draft, for example, purports to use a debt ceiling limitation mechanism to enforce the draft's balanced budget requirement. See S.J. Res. 1, 104th Cong. $\$ 2$ (1995), reprinted in Appendix; infra text accompanying notes 272-84. 

words, should the target be adjusted for economic conditions?

These issues may seem so technical as to seem unimportant. They are not. Almost a century of experience with the income tax has taught us that the success or failure of any system of financial controls depends on its choice of accounting rules. At the core of any income tax is a definition of income. Similarly, at the core of any balanced budget amendment is a definition of budgetary balance. A balanced budget amendment cannot be understood without some consideration of how the amendment addresses these seemingly unimportant technical issues. ${ }^{103}$

\section{A. Accounting for Spending and Income}

When should spending and income be recorded for balanced budget purposes? Readers whose only experience with accounting has been to balance a checkbook or file an income tax return may wonder what the issue is. Is it not obvious that money is spent when it is spent and income received when it is received? The answer, unfortunately, is: "Not necessarily."

In fact, two methods of accounting are commonly recognized: cash and accrual. There are many forms of each, but no generally accepted theoretical definition of either. ${ }^{104}$ For purposes of this Article, I will define a cash

103. All examples used in this Article are staled in nominal dollars-ihal is. dollars unadjusted for infiation.

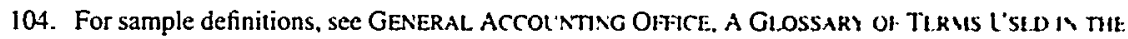
FEDERAL BUDGET PROCESS 19 (Exposure Draft Jan. 1993) (defining cash bass as "|r]he basis whereby receipts are recorded when received and expenditures are recorded when patd. whthout regard to the accounting period in which the receipts are earned or the costs incurred" and definang accrual basis as "[t]he basis whereby transactions and events are rocognized when they occur, regardless of when cash is received or paid"). Treasury regulations give the follow'ng defintuons:

Generally, under the cash receipts and disbursements method in the computation of taxable income, all items which constitute gross income ... are to be included for the taxable jear in which actually or constructively received. Expenditures are to be dedueted for the taxable year in which actually made. .. . Generally, under an accrual method. income is to be included for the taxable year when all the events have occurred that fix the nght to recesse the income and the amount of the income can be determined with reasonable accuracy. Under such a method. a liability is incurred, and generally is taken into account for Federal income tax purposes, in the taxable year in which all the events have occurred that establish the fact of the labalily. the amount of the liability can be determined with reasonable accuracy, and economic performance has occurred with respect to the liability.

Treas. Reg. § 1.446-l(c)(1)(i)-(ii) (as amended in 1995).

One court compared cash accounting to a lower form of the human spint

The cash method-simple, plodding. elemental-stands firmly in the physical realm fi responds only through the physical senses, recognizing only the tangible flow of currency Money is income when this raw beast actually fecls the coins in its primal paw; expenditures are made only when the beast can see that it has given the coins auay

Knight-Ridder Newspapers, Inc. v. United States, 743 F.2d 781.787 (1) th CIr 1984) On the other hand. accrual accounting inspired the coun to ecstatic discourse:

The accrual method, however, moves in a more ethereal, mystical realm. The visionan prophet. it recognizes the impact of the future on the present, and with grave foreboding or cestatic 
method as any method that reports financial transactions based on cash flows. Under a cash method, income is recorded when received; expenses are recorded when paid. I will define an accrual method as any method that reports financial transactions based on the substance of the reporting entity's activities and commitments. It attempts to look at what is really happening, not merely at when cash moves. It therefore typically records income when earned and expenses when incurred.

A financial system that seeks to measure something other than cash flows-such as income or consumption, for example-must use accrual accounting rules. Thus the so-called "cash method" used to measure income for federal tax purposes actually incorporates major elements of accrual accounting: capitalization and amortization rules, time-value-of-money adjustments, and a general substance-over-form rule, among others. ${ }^{105} \mathrm{~A}$ system of accrual rules may similarly be structured to measure consumption; under such a system, expenses would be recorded as consumption occurs. For example, the premium value of Social Security insurance might be recorded as an expense as the working population ages; we would not have to wait until benefits are actually paid. ${ }^{106}$ Conversely, the cost of a new highway would be amortized over its expected useful life. Only a balanced budget amendment using accrual rules can accurately measure consumption and therefore consistently protect the value of intergenerational equity.

Cash and accrual accounting differ in other important regards as well. The cash method is formal, mechanical, and easier for non-accountants to understand and implement. Legislators without financial or accounting expertise may find the cash method easier to use. On the other hand, accrual

anticipation, announces the world to be. When it becomes sure enough of its prophecies, it actually conducts life as if the new age has already come to pass. Transactions producing Id. income or deductions spring to life in the eyes of the seer though nary a dollar has moved.

105. In general, for federal income tax purposes, the cost of an asset whose useful life extends significantly beyond the end of the taxable year must be capitalized (that is, the cost must be added to the asset's basis), instead of being claimed as an immediate deduction. See Treas. Reg. $\$ 1.263$ (a)-2(a) (as amended in 1987). That cost is then amortized over the useful life of the asset-that is, a portion of the cost is allowed as a deduction for each year of the asset's useful life. See, e.g., I.R.C. § 167 (1996) (depreciation, amortization, and depletion generally); id. $\$ 168$ (depreciation of certain tangible property); id. $\$ 197$ (amortization of certain intangible property); id. $\$ 611$ (depletion of mineral deposits). The result is to match the costs of producing income to the resulting income, an accrual rather than cash method goal. Similarly, a number of Code provisions require the use of accrual rather than cash method accounting cven by cash method taxpayers to reflect more accurately the time value of money. See, e.g., id. $\$ 1272$ (original issue discount); id. $\S 1274$ (imputed interest on sales); id. $\S 7872$ (imputed interest rules generally). The principle that tax will be imposed on the substance, rather than on the form, of a transaction applics to both cash and accrual taxpayers. See, e.g., BORIS I. BITTKER \& JAMES S. EUSTICE, FEDERAL INCOME TAXATION OF CORPORATIONS AND SHAREHOLdERS 1-19 (1979).

106. This is not to suggest that the premium value represents consumption. However, taxes equal to the premium value are being paid, in effect, to purchase an annuity. To allow use of the same funds to finance current consumption would be to double-credit them. An alternative solution would be to exclude the Social Security system from the budget altogether, requiring it to be funded separately on an actuarially sound basis. 
accounting, with its focus on the substance of an organization's activities and commitments, generally provides a more accurate picture of an organization's finances. ${ }^{107}$ The timing of cash flows can easily be manipulated. The timing of an organization's actual activities and commitments, by contrast, are subject to external constraints. Even if they are manipulated for tax, reporting, or budget balancing purposes, the resulting changes reflect real changes in the organization's financial situation. For this reason, the financial repors of all major corporations are required to be prepared in accordance with "generally accepted accounting principles," a body of accrual rules developed by the financial accounting community. ${ }^{108}$ For the same reason, large businesses are required to use accrual accounting for U.S. income tax purposes. ${ }^{109}$ Even the federal government has begun to move into the accrual age for internal management purposes. ${ }^{110}$ In this respect, the 1995-96 Senate Draft, with its reliance on pure cash flow accounting, is a dinosaur.

The 1995-96 Senate Draft is built around two basic rules." "First, for any fiscal year, outlays may not exceed receipts. Section 1 states: "Total outlays for any fiscal year shall not exceed total receipts for that fiscal year, unless three-fifths of the whole number of each House of Congress shall

107. See United States v. Catto, 384 U.S. 102, 116 (1966): 2 DepartMENT OF nit TrEast RY, supro note 92, at 215-16; Michael J. GRaetz \& Deborah H. SCHenk. Federal Income Taxation 713 (3d ed. 1995); OfFICE OF MANAGEMENT \& BUDGet, OBJECTIVES OF FEDERAL. FISAICIAL. REPORTIMG STATEMENT OF FEDERAL FINANCIAL ACCOUNTING CONCEPTS No. 1. at 65 (Sept. 1993) (stating that cash basis accounting is unacceptable for GAAP): STANLEY S. SURRIE ET AL. FEDERAL I TCOME TAXATION 579-81 (successor ed. 1986).

108. See 1 Department of the TREasury, supra nole 92. al 216. Stailliy Sitged. \& David A Siegel, AcCounting and Financial Disclosure: A GLide to Basic Concerts 35 (1983). sec. $e g$. In re Multi Benefit Realty Fund, 1976 SEC LEXIS 2210, 2- (1976) (stating that financtal statements filed with SEC must be on accrual basis as required by generally accepled accountung pnneiples because "cash basis financial statements are necessarily distorted to some extent"): 12 C FR.\$335627 (1996) (requiring accrual method); 17 C.F.R. \$ 4.25(a)(7)(i) (1996) (same).

109. See I.R.C. $\$ 448$ (1996). See generally STAFF OF THE JOINT COMMITTE ON TA MATIO S. GENERAL EXPLANATION OF THE TAX REFORM ACT OF 1986, at 474-75 (1986) (requinng large businesses to use accrual method).

110. See, e.g., Office of MaNagement \& Budget, AccolntiNg for Selected Assets a do LIABILITES, STATEMENT OF FEDERAL FINANCIAL ACCOUNTING STANDARDS No. I possim (Mlar 1993) (proposing use of accrual accounting for federal financial accountung and reportung purposes). OFFICE OF MANAGEMENT \& BUdGet, MANAGERIAL COST ACCOUNTING CONCEPTS AND STA DARDS FOR THE

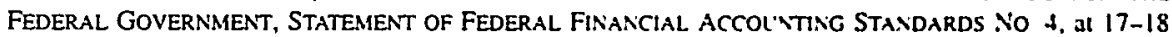
(July 1995) (using accrual method, not cash method, for managenal cost accouning): see also OfFicE of MANAGEMENT \& BUDGET, ACCOUNTING FOR INVENTORY AND RELATED PROPERTY, STATEMENT OF FEDERAL FinANCIAL ACCOUNTING STANDARDS No. 3. al 9.13 (Oct. 1993) (recommending consumplion method of accounting for operating materials and supplies and for stockpıle matenals) The federal Bureau of Economic Analysis already computes an acerual method deficit figure as pan of its "national income and product accounts," commonly known as NIPAs. See CONGRESSIONAL BLDGET OFFICE supra note 46. at 125-29. Baseline deficit projactions using the NIPA accrual method currently antscipate larger deficts in the next several years than those projected using Congress's current modified cash method Compare id. at 128 tbl.D-2 (listing NIPA accrual method projected deficits), wih id. al xill (summary tbl.3) (listung modified cash method deficits).

111. Section 3 of the draft also requires that the President each year submit a proposed budget for the United States Government in which total outlays do not exceed total receipts. See SJ Res. 1. 10tith Cong. $\S 3$ (1995), reprinted in Appendix. 
provide by law for a specific excess of outlays over receipts by a rollcall vote."112 Second, a supermajority vote is needed to increase the limit on U.S. debt held by the public. Section 2 states: "The limit on the debt of the United States held by the public shall not be increased, unless three-fifths of the whole number of each House shall provide by law for such an increase by a rollcall vote." 113

What do these rules mean? Both invoke the cash method of accounting, which generally takes expenses into account when cash actually flows-that is, when the expenses are paid. On this issue, section 2 is clear: Because as a practical matter borrowing is not necessary unless and until cash actually passes, section 2 uses pure cash accounting. The answer is somewhat less clear under section 1, which prohibits "outlays" in excess of "receipts." For budgetary purposes, Congress currently computes "outlays" and "receipts" on a cash basis, but not on a pure cash basis. ${ }^{114}$ It might be argued that section 1 is intended to constitutionalize existing practice, not pure cash accounting. Neither the draft itself nor the accompanying 1995 Senate committee report explicitly addresses this question. If "outlays" and "receipts" are interpreted to refer to pure cash flows, however, the relationship between sections 1 and 2 becomes clear and elegant: Section 1 simply mandates a budget that does not require the government to borrow. So read, section 1 is almost identical in substance to section 2. Section 1 articulates the principle; section 2 enforces it. Consistent with this reading, the 1995 Senate committee report states that section 2 is intended to constitute the "primary enforcement mechanism" for the amendment as a whole. ${ }^{115}$

The distinction is important because a numerical test can only control what it measures. If an amendment only measures cash flows, then it can only control cash flows. Congress may authorize any spending it wishes. The government may order and consume any goods or services it wants. Unless and until the bill is actually paid, there can be no violation of the amendment. The inaccuracies of the cash method, in turn, create substantial enforcement problems for any balanced budget amendment that invokes it. To explore all such problems here would be impractical; a few illustrations should suffice.

112. See id. $\S 2$.

113. See id. Many state balanced budget provisions are similarly framed as debt limitation provisions. See Kiewiet \& Szakaly, supra note 11, passim (reviewing state constitutional limitations on borrowing); Sterk \& Goldman, supra note 11 , at 1305-06 (same).

114. See infra notes $166-69$ and accompanying text.

115. See S. REP. No. 104-5, at 8 (1995). Any other reading of section 1 leads to anomalous results. If "outlays" and "receipts" are computed other than on a pure cash basis, the tests imposed by sections 1 and 2 will differ. It is unclear why the draft would impose two different balanced budget tests; the 1995 Senate committee report evidences no such intention. More importantly, the report strongly suggests that section $I$ is not self-enforcing; enforcement of the principle set forth in section 1 is to be provided by section 2. See id. If this is true, however, the two sections must use the same accounting method: purc cash accounting. 


\section{Treatment of Unpaid Obligations}

Perhaps the most flagrant inaccuracy of the cash method is its treatment of unpaid obligations: It ignores them. For income tax purposes, this is not a problem. Unpaid obligations represent potential deductions, and it is in the government's interest to permit taxpayers to ignore deductions. ${ }^{116}$ For financial reporting purposes, however, this kind of inaccuracy is a major problem. Any accurate picture of an organization's finances must include unpaid obligations. Consequently, use of the cash method is prohibited in corporate reports to investors and shareholders. ${ }^{117}$

The same considerations suggest that unpaid obligations should be taken into account in assessing the federal government's financial status as well. Congress may obligate the government in ways that ensure financial catastrophe. As long as no actual payment is made, however, the cash method will report that all is well. This is fundamentally inconsistent with the value of institutional responsibility, which even the most simpleminded balanced budget amendment should protect.

Assume, for example, that Congress authorizes the issuance of twenty-year zero-coupon bonds having a face value of $\$ 20$ trillion-that is, twenty-year bonds that pay no interest but require the government to pay the holders $\$ 20$ trillion at maturity. The Treasury issues the bonds for $\$ 5$ trillion in cash and uses the proceeds to pay off all existing U.S. indebtedness. ${ }^{118}$ Financial theory tells us that these bonds are approximately equivalent to bonds in the face amount of $\$ 5$ trillion paying interest annually at a rate of $7.18 \%$. For this reason, under the accrual method a corporate issuer of such bonds would be required to accrue the equivalent of interest on such bonds every reporting period even though no interest is actually paid. ${ }^{119}$

Under a pure cash method, however, expenditures are only reponed when paid. ${ }^{120}$ If the cash method is used to account for the foregoing transaction, the effect will be to eliminate all interest expense from the federal budget for the first nineteen years, thereby balancing the budget beyond the expected terms of most members of Congress without any painful spending cuts or tax increases whatsoever. The problem, of course, is that in the twentieth year. Congress will

116. Indeed, the income tax rules even place accrual method taxpayers on the cash method with respect to some deductions. See I.R.C. \$ 461(h) (1996).

117. See supra note 108 and accompanying text.

118. As of December 31, 1995, the gross federal debt was estumated to be $\$ 4.92$ inllion. See DEPARTMENT OF THE TREASURY, supra note 20, at 189.

119. See I.R.C. §§ 163(e), 1272-73.

120. Because of the significant inaccuracies of the cash method in this context. even cash method taxpayers are generally required to use accrual accounting in reponing the implicit interest-known in the Internal Revenue Code as "original issue discouni"-for federal income tax purposes. See id. \$ 1272 Currently, similar rules are imposed for debt issued to the public under the vanation of cash method accounting used for federal budgetary purposes. See DEPARTMENT OF THE TREASLRY, supra note 20, at 334. 
have to come up with $\$ 20$ trillion to pay off the bonds-a budgetary time bomb waiting to go off.

I do not suggest that Congress would be so irresponsible as to balance the budget in the manner discussed above. ${ }^{121}$ My point is rather that a balanced budget amendment that permits Congress to do so is fundamentally inadequate. Moreover, there are many more arcane and less understandable ways of reaching similar results. ${ }^{122}$ Readers skeptical of my hypothetical should note that the Treasury already issues long-term zero-coupon bonds. We know them as "savings bonds." ${ }^{123}$ To circumvent an amendment that uses pure cash method accounting, Congress would merely have to alter the mix of debt instruments it already authorizes. ${ }^{124}$

The potential for avoidance created by this inaccuracy of the cash method arises any time the government incurs an obligation that it does not immediately pay. The largest budgetary time bomb now waiting to go off is Social Security, which involves massive future payments that Congress has obligated the government to make but which, under the cash method, have no current budgetary impact. ${ }^{125}$ Any balanced budget amendment that allows Congress to ignore the largest budgetary problem it now faces is of questionable integrity. ${ }^{126}$ Indeed, to the extent that a cash method balanced budget amendment forecloses other methods of bidding for reelection, it may even encourage the creation of similar unfunded liabilities in the future. By contrast, as has been noted, ${ }^{127}$ under an accrual method amendment the premium value of future benefits would be recorded as a current expense, thus forcing Congress to deal with the problem in advance and protecting future generations from potential governmental default.

121. Under existing statutory federal budgetary accounting rules, deemed intcrest on zcro-coupon bonds must be accrued currently. See DEPARTMENT OF THE TREASURY, supra note 20, at 335 . This treatment, though, is within Congress's control and is acknowledged to represent one of several limited exceptions to the general rule of cash method accounting. See id. at 334-35.

122. Some of the better-known ways to structure nondebt financings that are indistinguishable from zero-coupon bonds as a matter of financial theory are described in Alvin C. Warren, Jr., Commentary, Financial Contract Innovation and Income Tax Policy, 107 HARV. L. REV. 460 (1993). The Treasury Department has recently proposed comprehensive regulations in an attempt to curtail use of such instruments for tax avoidance purposes. See Prop. Treas. Reg. $\$ 1.1275-6,59$ Fed. Reg. 64905 (1994).

123. Savings bonds are exempted from tax rules that require current accrual of original issue discount. See I.R.C. $\$ 1272(\mathrm{a})(2)(\mathrm{B})$.

124. Ultimately, of course, the financial markets will penalize irresponsible governmental behavior, if only by imposing higher interest costs on governmental borrowings. Relying on such market constraints to prevent borrowing deemed excessive, however, is inconsistent with the purposes of a balanced budget amendment. Such market constraints already exist; by adopting a balanced budget amendment, we have necessarily concluded that market constraints are inadequate. States often face higher interest rates on borrowings structured to circumvent similar constitutional provisions; such borrowings are nevertheless common. See supra note 11 .

125. A review of the projected budgetary impact of Social Security and related programs appears in a 1996 CBO study. See CONGRESSIONAL BUDGET OFFICE, supra note 46, at 69-95.

126. The issue is not merely financial. An amendment that forces Congress to resolve the uncertainties of Social Security today would allow future potential beneficiaries-including the author of this Article-10 rely on the government's promises.

127. See supra note 106 and accompanying text. 


\section{Treatment of Capital Expenditures and Receipts}

A second inaccuracy of the cash method is its treatment of the purchase and sale of assets, both capital assets ${ }^{128}$ and inventory. For the U.S. government, Stealth bombers, bullets, federal office buildings, national parks, oil rights in the continental shelf, the Strategic Petroleum Reserve, gold in For Knox, Japanese yen held by the Federal Reserve Bank, and the name "United States of America" all fall in this category. ${ }^{129}$

Under pure cash method accounting, the purchase of an asset is treated as a current expense, and receipts on the sale of the asset are treated as income. If the government buys $\$ 100$ worth of gold, then sells it for $\$ 100$ cash, pure cash method accounting treats the purchase as a $\$ 100$ "outlay" and the sale as a $\$ 100$ "receipt." This treatment, while simple and mechanical, is unrealistic. When the government exchanges cash for gold, it is not, as a result, $\$ 100$ poorer; it is not, in the rhetoric of balanced budget concerns, $\$ 100$ closer to bankruptcy. Conversely, when it converts the same gold back into cash, it is not $\$ 100$ richer. It has merely converted wealth from one form into another.

For this reason, even cash method taxpayers are required to use accrual accounting ${ }^{130}$ for capital assets and inventory in computing their federal taxable income. ${ }^{131}$ In general, a taxpayer who buys such an asset cannot deduct its cost. Instead, the taxpayer is assigned a basis in the asset equal to its cost. ${ }^{132}$ If the asset is used in the production of income, that cost is then amortized over its useful life, ${ }^{133}$ reducing the taxpayer's basis as the deductions are allowed. ${ }^{134}$ When the taxpayer sells the asset, income is recognized only to the extent that the sales price exceeds the taxpayer's remaining basis in the asset. ${ }^{135}$ These rules more accurately reflect economic reality and are now used for almost all tax and financial accounting purposes. ${ }^{136}$

128. By use of the term "capital asset," I mean to invoke its common meaning-an assel, other than inventory, having a useful life extending beyond a single reporung penod-not the more restnctuve technical meaning assigned to it in I.R.C. $\S 1221$.

129. Currently, the Office of Management and Budget groups federal investment outlays into three main categories: physical investment, research and development. and educatuon and tranıng See DEPARTMENT OF THE TREASURY, supra nole 20, at 92-93.

130. Although tax lawyers sometimes view the requirement that capital expenditures be capitalized as inherent to the cash method, the intention of the requirement is 10 match expenses to income, the goal of accrual accounting-not to track cash fows, the goal of cash accounting. See Treas. Reg $\$ 1$ \$61 (c)(2)(i) (as amended in 1995) (defining inventory accountıng as accrual method)

131. See I.R.C. $\S 263$ (discussing capital expenditures): Treas. Reg. $\$ 1+46-1(0)(2)(1)$ (as amended in 1995) (discussing inventory).

132. See I.R.C. $\S 1012$. Basis is an attribute of an asset used to keep trach of a taxpayer's deemed investment in the asset for tax purposes. See generally. Glen Arlen Kohl. The Identification Theon of Basts. 40 TAX L. REV. 623 (1985).

133. See I.R.C. $\$ 167$.

134. See id. $\S 1016(a)(2)$.

135. See id. $\$ 1001(\mathrm{a})$.

136. Similar principles have been suggested. but not adopted. for federal budgetan accounung purposes. See COX ET AL., supra note 41, at 18-21. 
In the context of a balanced budget amendment, the inaccuracies of pure cash accounting for asset purchases and sales create both incentives for distorted decisionmaking and avoidance potential. ${ }^{137}$ Let us consider incentives for distorted decisionmaking first. Assume that Congress must choose between two solutions to a problem. One will cost $\$ 40$ billion today but will solve the problem for forty years. The other will cost $\$ 4$ billion today but will solve the problem only for the budgetary year in question. Assume further that a financially prudent decisionmaker, operating without artificial constraints, would adopt the long-term solution, which costs an average of $\$ 1$ billion per year, over the short-term solution, which costs $\$ 4$ billion per year. The cash method will obscure the solutions' relative efficiencies. The long-term solution will have an immediate $\$ 40$ billion impact on the budget; the short-term solution an impact of only $\$ 4$ billion. A Congress operating under the imperatives of a cash method balanced budget rule may feel constrained to choose the latter, even though the former is more economically rational. An accrual method, by contrast, can be structured to reflect correctly the relative financial merits of the two choices. ${ }^{138}$

A second distortive effect of this aspect of cash method accounting is an artificial incentive to sell federal assets. Under the cash method, a sale of Yosemite National Park is treated as increased wealth for the federal government. The government may then use that extra "wealth" to finance current operations. In reality, of course, a sale of Yosemite at market value does not change the government's wealth at all; it merely represents the conversion of one kind of wealth into another. Spending down the nation's wealth to finance current operations is unfair to future generations and is, in substance, a form of deficit spending. A cash method balanced budget amendment encourages such spending.

Supporters of smaller government may welcome this aspect of the cash method because the sale of federal assets arguably makes the federal government smaller. I have already suggested that the use of a balanced budget amendment for this purpose is inappropriate. ${ }^{139}$ An additional problem with using a cash method balanced budget amendment for this purpose is that, under the cash method, there is no lower limit to the incentive; smaller is always better. After the less-used national parks are sold, ${ }^{140}$ the amendment still gives Congress an

137. Perhaps for these reasons, some senators have advocated the creation of a separate capital budget. See, e.g., S. REP. No. 104-5, at 28 (1995) (statement of Sen. Biden); id. at 54 (minority views of Sens. Kennedy, Leahy, and Feingold). A separate capital budget is necessary only if operating accounts are kept on a pure cash basis.

138. It has been noted that if capital expenditures are spread relatively evenly over time, the net impact on the budget will be the same regardless of how they are accounted for. See MUSORAVE, supra note 37, at 558-62. While true, this statement ignores the incentive effects of the cash method at each decision point. See id. at 562 .

139. See supra Subsection I.C.3.

140. Proposals to sell off the less-used national parks and monuments to help balance the federal budget have circulated recently in Congress. See National Park System Reform Act of 1995, H.R. 260, 104th Cong. (1995). These proposals have met with wide criticism. See, e.g., 141 CoNO. REC. H9086 (daily ed. Sept. 18, 1995) (statement of Rep. Richardson); America For Sale, ST. LOUIS POST-DISPATCH, July 17. 1995, at 6B; Don't Close The Parks, SALT LAKE TRIB., May 6, 1995, at A12; For Sale: National Parks. 
incentive to sell off the more popular parks, then the gold at Fort Knox, then the Strategic Petroleum Reserve, ${ }^{141}$ then less vital military bases, then the bombers and missiles themselves. In fact, under a cash method balanced budget amendment, the ideal size of the federal government is zero. ${ }^{142}$

Perhaps as troublesome as the distortive effects of this aspect of the cash method is its avoidance potential. Consider the following transaction. The government, forced to balance the budget but seeking also to retain Yosemite for future generations, sells the park to private investors but leases it back for a $100-$ year term, renewable indefinitely at the government's option. In substance, the government keeps the park but receives a large sum of money today that it will then pay back, together with a market return, over the next century. Accrual accounting, which focuses on the economic substance of the transaction (commonly known as a "sale-leaseback"), treats it as a loan if it has no economic substance. Because of the avoidance potential of sale-leasebacks, tax rules require such treatment even for cash method taxpayers. ${ }^{143}$ An accounting method that focuses strictly on cash flows, however, may treat the sales proceeds as "receipts," which can then be used to finance other governmental operations. ${ }^{1+4}$ Under a cash method amendment, the sale-leaseback gives Congress yet another possible tool to meet the technical requirements of the amendment without, in fact, balancing the budget. ${ }^{145}$

Miam! Herald, June 27, 1995, at A8. But see 141 CoNG. ReC. H9086-87 (daily ed Sept. 18. 1995) (statement of Rep. Hefley) (arguing that H.R. 260 is not "park-closing bill").

141. See Ralph Vartabedian, Dipping Into the Sirategic Petroleum Resenie. L.A. Tives. May 9. 1996. at D1 (discussing sales from Strategic Petroleum Reserve to help balance budget)

142. I do not contend that a cash method balanced budget amendment would result in the disappearance of the federal government. Countervailing political fores would clearly operate 10 limit Congress's ability to sell assets for which there are strong constituencies. My contention rather is that a systemic incentive to sell federal assets would diston federal decisionmaking in ways elther unrelated or contrary to the values the amendment is supposed to implement.

143. See, e.g., JACOB MERTENS, JR., THE LAW OF FEDERAL INCONE Taxation \$ 6A.74 (1994) (discussing tax treatment of sale-leasebacks for both accrual and cash method caxpayers).

144. One might consistently adopt the cash method and still treat sale-leasebacks as loans. The resuit would be to treat such sale proceeds as loan proceeds for purposes of section 7 of the 1995-96 Senate Draft. See S.J. Res. 1, 104th Cong. $\S 7$ (1995), reprinted in Appendix. This possibility. however. merely raises again the basic question posed by any accounting method other than pure cash accountung: Who defines the rules? If Congress has the power to define the treatment of sale-leasebacks for constututional purposes, the avoidance potential remains.

145. Current budget nules recharacterize lease-purchase transactions as debi-financed purchases. See DEPARTMENT OF THE TREASURY, supra note 20, at 334-35. No such recharacterizanton rules are currently applied to sale-leasebacks. Indeed, the use of the sale-leaseback as a governmental financing technique appears to be relatively common. See STAFF OF JOINT COMM. ON TAXATION, 98Th CONG.. TAX ASPECTS OF FEDERAL LEASING ARRANGEMENTS 22-27 (1983) (examining policy issues, including budgetary accounting issues, raised by governmental leasing): Ira P. Robbins. The Legal Dimensions of Prvate Incarceration, 38 AM. U. L. REV. 531, 630-32 (discussing sale-leaseback iechniques for pnsons): Michael H. Schill, Note, The Participation of Charities in Limited Parmerships, 93 YALE LJ. 1355. 1373 (1984) (noting that federal, state, and local govemments have used sale-leaseback techniques to take advantage of tax benefits). 


\section{What is Cash?}

Since the cash method focuses on flows of cash, flows of anything else may escape the limitations of a cash method amendment. The definition of cash therefore becomes critical. Consider the following transaction: The government uses $\$ 100$ worth of silver to pay for $\$ 100$ worth of services, which it immediately consumes. How we treat this transaction under a cash method amendment will depend on whether silver is considered property or cash. If we treat it as property, then the transaction is economically indistinguishable from a sale of silver for $\$ 100$ and a purchase of services for $\$ 100-$ a $\$ 100$ receipt coupled with a $\$ 100$ outlay. In other words, our budget is balanced. If instead we treat silver as cash, there is only one transaction, a $\$ 100$ purchase of services-a $\$ 100$ outlay. Our budget now shows a deficit of $\$ 100 .^{146}$

Of course, if the technique requires the government to own the silver it sells, the government may not own enough silver to make this an interesting issue. Here is where modern financial markets come to the government's rescue. Assume that the government receives the $\$ 100$ but does not immediately deliver the silver to its buyer. In fact, it does not own any silver at the time of sale; in financial parlance, it sells the silver "short." Assume further that the government's promise to deliver the silver is evidenced by a certificate, which I will call a "silver certificate." A silver certificate, in this hypothetical, evidences the holder's right to receive a specified amount of silver, measured in grams, from the government. Using short sales, the government can print and sell an indefinite quantity of such certificates; its ability to sell short is limited only by public confidence in its ability to perform the executory promises evidenced by certificates outstanding. The government need not own any silver at all.

What the government has done in our hypothetical is to print something that looks suspiciously like money. Our hypothetical "silver certificates" differ from the "silver certificates" that the United States historically issued as currency in two principal regards: They are denominated in grams of silver, not in dollars, and they are not, as a matter of law, "legal tender." Nevertheless, they can be spent. So long as silver is treated as property, under a cash method balanced budget amendment Congress may spend as much of this new "money" as it likes without creating any deficit, because the cash method treats the transfer of such an instrument as a short sale of silver (triggering $\$ \mathrm{X}$ of receipts) coupled with a purchase of whatever the government has bought (triggering $\$ \mathrm{X}$ of outlays).

Closing this loophole is not easy. Defining money as something that governments issue in the exercise of their sovereign powers will not work. In our hypothetical, the United States has not performed any governmental function or

146. Although silver has sometimes been used as a medium of exchange, in the modern world we nomally treat it as a commodity, that is, as property. On the other hand, in our hypothetical, the government is in fact $\$ 100$ poorer when the transaction is over; it has spent a portion of its wealth to fund current operations. If we fail to treat this silver as cash, we have opened a hole in the rules. 
exercised any governmental power whatsoever. ${ }^{|4\rangle}$ It has merely paricipated in existing private markets and evidenced its obligations within those markets by issuing bearer certificates. Anyone can print "money" using this technique. The only reason the U.S. government can do so more credibly is that its credit rating is better. Defining silver, gold, and other quasi-monetary commodities as "cash" will not solve the problem either. ${ }^{148}$ The same technique will work with any fungible commodity: uranium, wheat, crude oil, morgage pools, or pollution emission rights.

Again, I have used a relatively simple and obvious example to illustrate the problem. It seems unlikely that Congress would authorize shon sales of silver. But government-sponsored entities already routinely sell financially sophisticated interests in other fungible commodities-mortgage pools, for example. ${ }^{1+9}$ And short sales are hardly the most difficult-to-understand instruments available in modern financial markets. The use of more sophisticated and less obvious techniques to create cash surrogates would substantially complicate the enforcement of a cash method amendment.

\section{What is Debt?}

Section 2 of the 1995-96 Senate Draft requires a supermajority vote to increase the "limit on the debt of the United States held by the public."1(5) The 1995 Senate committee report states that for this purpose, "debt" is defined by reference to current federal accounting usage, where the term is limited to formally issued, transferable debt instruments. ${ }^{|s|}$ Section 7 of the 1995-96

147. Under current federal budgetary rules, seigniorage. the profit from coining mone). is exiluded from receipts and is treated as a means of financing the deficit other than borrowing from the public Ser DEPARTMENT OF THE TREASURY, supra note 20, at 336-37. Seigniorage. however. anses from the evercise of the government's monetary power, see id., which is not involsed in the text's hy pothelical

148. Under current federal budgetary rules, gold-but not silver. platunum. of any other quasi-monetan commodity -is treated as a "monetary asset." Its sale is therefore accounted for as a borrouing See id at 336. Other "monetary assets," under current rules, include U.S. deposits with the Intemational Monetan Fund and holdings of foreign currency by the Exchange Stabilization Fund. See id. at 337

149. For descriptions of the activities of govemment-sponsored entues in the secondan marhet for mortgages, see, e.g., Paula C. Murray \& Beverly L. Hadawas. Mlortgage-Bucked Securities An Investigation of Legal and Financial Issues, 11 J. CORP. L. 203, 209-10 (1986) (dexinbang secondary market activities of Ginnie Mae, Fannic Mae, and Freddie Mac), and Joseph C. Shenker \& Anthony J Colletta, Asset Securitization: Evolution, Current Issues and New Frontiers. 69 Tix L REV 1369. 1383-88 (1991) (same). The sophistication of instruments issued by such entllies is suggested by the fact that among the derivatives involved in the Orange County bankruplcy were instruments issued by Fannte Mae and Freddie Mac. See Jeanette Redmond, Note. State and Local Governmental Enthies In Search of ... Statutony Authorin to Enter into Interest Rate Swap Agreements. 63 FoRDHAy L RE 2177. 2212-13 (1995) (recommending how state legislatures safely could pennil govemment units to use interesi rate swap agreements to reduce risks and costs); see also John Connor. Inqun Lusunched of Derusauses Used By Both Fannie Mae and Freddie Mac, WALL ST. J.. July 5. 1994. al CI8 (reporung investigation of derivatives issuances by government-sponsored entities).

150. S.J. Res. 1, 104th Cong. $\$ 2$ (1995), reprinted in Appendix.

151. See S. REP. No. 104-5, at 16 (1995). There is one major exception: Certain lease-purchase transactions are treated as though the asset leased has in fact been purchased outnght in exchange for debt See DEPARTMENT OF THE TREASURY, supra note 20, al 334-35. This nile. however, is intended to preserve 
Senate Draft similarly defines "receipts" to include "all receipts of the United States Government except those derived from borrowing" and "outlays" to include "all outlays of the United States Government except for those for repayment of debt principal'; 152 section 1 then prohibits outlays in excess of receipts in the absence of a supermajority vote. ${ }^{153}$ For purposes of these sections, the 1995 Senate committee report states: "It is intended that those obligations the title to which can be transferred by the present owner to others, like Treasury notes and bonds, be excluded from receipts." 154

The 1995-96 Senate Draft's definition of debt is thus consistent with the purest, most formalistic mode of cash accounting. As has already been noted, the cash method ignores unpaid obligations. ${ }^{155}$ In reality, of course, an unpaid obligation is a debt. Under the cash method, therefore, many types of debt-under the Draft's unusually formalistic approach, any debts that are not formally issued and transferable-are simply ignored. ${ }^{156}$ This creates obvious opportunities for circumvention. In late 1995 and early 1996, for example, the Treasury converted debts owed to several trust funds into unpaid obligations, thereby circumventing statutory limits on the national debt; $;^{157}$ the 1995-96 Senate Draft would apparently permit unlimited use of such techniques in the future.

Indeed, any balanced budget amendment that relies on a formalistic definition of debt invites circumvention. Techniques for creating synthetic debt-instruments that look and act like debt but are made up of components that are formally treated as something else-have become extremely sophisticated in recent years, triggering extensive theoretical commentary ${ }^{158}$ and major Internal Revenue

the integrity of cash accounting for asset purchases, not to preserve the integrity of the definition of debt. There is no corresponding rule for sale-leasebacks.

152. S.J. Res. 1, 104th Cong. $\$ 7$ (1995), reprinted in Appendix (emphasis added).

153. See id. §1.

154. S. REP. No. 104-5, at 19.

155. See supra Subsection II.A.I.

156. Thus accounts receivable held by cash method taxpayers are only treated as debts for bad debt deduction purposes if they have already been taken into income. Conversely, accounts payable of cash method taxpayers for trade or business expenses are treated as debts for discharge of indebtedness income purposes if they have already triggered a deduction. The relationship between accounting methods and the definition of debt for tax purposes is explored in Theodore P. Seto, The Function of the Discharge of Indebtedness Doctrine: Complete Accounting in the Federal Income Tax System, 51 TAX L. REV. (forthcoming 1997).

157. See Budget Impasse: U.S. Taps Trust Funds as Interest Comes Due, L.A. TIMES, Nov. 16, 1995, at 16; Frank James, Congress Reaches for Solution on Debt Ceiling: President May OK Bill with 'Strings', CHI. TRIB., Jan. 31, 1996, at 4; David E. Sanger, Treasury Secretary Takes a Risk to Sidestep an Even Bigger One: U.S. Default, N.Y. TIMES, Nov. 16, 1995, at B12.

158. See, e.g., David P. Hariton, The Taxation of Complex Financial Instruments, 43 TAX L. REV. 731 (1988) (discussing taxation of contingent obligations, fixed obligations with variable interest payments, foreign currency instruments, debt-equity hybrid instruments, and convertible debt obligations); Edward $D$. Kleinbard, Equity Derivative Products: Financial Innovation's Newest Challenge to the Tax System, 69 TEX. L. REV. 1319 (1991) (discussing taxation of equity derivatives); Scott Marc Kolbrenner, Derivatives Design and Taxation, 15 VA. TAX REV. 211 (1995) (same); Reed Shuldiner, A General Approach to the Taxation of Financial Instruments, 71 TEX. L. REv. 243 (1992) (proposing uniform rules for taxation of financial instruments); Jeff Strnad, Taxing New Financial Products: A Conceptual Framework, 46 STAN. L. REV. 569 (1994) (proposing taxonomy of tax systems for financial instruments); Warren, supra note 122 (examining problems posed by financial contract innovation and possible approaches to coherent taxation). 
Service efforts to recharacterize synthetic debt as debt for tax purposes. ${ }^{(5)}$ Onc can anticipate that under a cash method balanced budget amendment similar problems would arise eventually, if not immediately.

Even the use of sophisticated techniques, however, may not be necessary if simpler circumventions remain available. Debt is not the only type of instrument a corporate entity may issue to raise funds; it may also issue stock. During its early years, the United States government did just that, redeeming its "stock" through sinking fund mechanisms typical of preferred stock issued contemporaneously by private corporations. ${ }^{160}$ The Louisiana Territory, for example, was purchased by giving the French govemment "stock," not debt. ${ }^{161}$ More recently, Congress financed the Resolution Trust Corporation, a corporation deemed part of the government for budgetary purposes, in significant part. through the issuance of "capital certificates" to the Resolution Funding Corporation, a "private" corporation the sole purpose of which was to purchase those certificates, which purchase was in turn financed by borrowing from the public. ${ }^{162}$ The result was to place some $\$ 30$ billion of borrowing completely offbudget. Such stock issuances would remain off-budget in the future under the 1995-96 Senate Draft.

Recharacterizing such stock as debt is problematic. Such recharacterization is possible for income tax purposes in very limited circumstances, but Congress could probably structure stock issuances so as to resist recharacterization under similar rules. ${ }^{163}$ Unless stock issued by a federal instrumentality is treated as debt for balanced budget purposes, however, the use of stock offers virtually unlimited potential for circumvention under any cash method amendment resembling the 1995-96 Senate Draft.

159. See Prop. Treas. Reg. § 1.1275-6, 59 Fed. Reg. 64.905 (1994).

160. See KEARNY, supra note 86, at 61 .

161. See supra note 87.

162. See, e.g., Marirose K. Lescher \& Merwin A. Mace Ill, Financing the Ballout of the Thrift Crists Workings of the Financing Corporation and the Resolution Funding Corporation. 16 BLS. LAW S07. 521-28 (1991) (describing use of Resolution Funding Corporation to place debt off-budget); Kenneth Ryder, Savings \& Loan Crisis: Lessons and a Look Ahead: A Gude to FIRREA's Off-Budget Finaneing. 2 STAN. L. \& POL'Y REV. 82 (1990) (same). Essentially the same structure was used to place some SIS billion of borrowing off-budget to finance the Federal Savings and Loan Insurance Corporation See Lescher \& Mace, supra, at 510-20; Ryder, supra, at 85.

163. See, e.g., Full Service Beverage Co. v. Commissioner, 69 T.C.11. (CCH) 2221, 2225-27 (1995) (refusing to accept petitioner's characterization of stock as debt): Estale of Scholl s. Commussioner. 43 T.C.M. (CCH) 1188, 1195, 1200-01 (1982) (same); Miele v. Commissioner, 56 T.C. 556. 561-66 (same). aff'd without opinion, 474 F.2d 1338 (3d Cir. 1971), aff'd without opinton sub nom. Spintello $v$ Commissioner, 475 F.2d 1396 (3d Cir. 1973); Ragland Inv. Co. v. Commissioner. S2 T.C. 867. 875-79 (1969) (same), aff'd 435 F.2d 118 (6th Cir. 1970); Zilkha \& Sons, Inc. v. Commissioner. 52 TC. 607. 612-13 (1969) (same), acq. 1970-1 C.B. xvi. But see Gen. Couns. Mem. 34.529 (June 18. 197I) (arguing that nominal preferred stock may constitute indebtedness). See generally William T. Plumb. Jr. The Federal Income Tax Significance of Corporate Debr: A Critical Analysis and a Proposal, 26 TAX L REV. 369 (1971) (discussing distinction between debt and equity for tax purposes). 


\section{Constitutional Implications of a Choice of Accounting Methods}

Constitutional lawyers may wonder what the problem is. Why not simply adopt an accrual method balanced budget amendment, that is, an amendment that looks at the substance of the government's activities, not merely at their form? Tax lawyers and accountants, on the other hand, may complain that I have caricatured the cash method. We use a modified version of the cash method for tax purposes, imposing accrual rules whenever necessary to solve at least some of the problems identified in the foregoing pages. Why not permit use of such a hybrid system for balanced budget purposes as well?

The problem is that, in general, accrual accounting only works with outside supervision. Because accrual accounting focuses on the substance of the reporting entity's activities, some judgment is always required to translate that substance into numbers; and because the reporting entity almost always has an incentive to bias that judgment in one direction or another, its judgment requires outside review. This is not a problem in the private sector. One of the principal functions of the Internal Revenue Service is to identify and prevent taxpayer abuse of accounting rules. Similarly, certified financial statements are reviewed by independent certified public accountants. ${ }^{164}$

An accounting method that requires routine outside review of a legislature's judgments, however, raises potentially serious separation of powers issues. ${ }^{165}$ It is principally for this reason, I suggest, that governments have continued to use cash accounting for financial control purposes notwithstanding the fact that, by modern standards, the cash method is unacceptably primitive. It is also for this reason that $I$ have used pure cash method accounting as a starting point for my examination of the problems of that method; every deviation from an accounting method based strictly on cash flows requires that the same constitutional questions be asked anew. This may be why the 1995-96 Senate Draft seems to invoke the purest, most formal cash accounting techniques.

Current federal budgetary rules reflect this linkage between accounting and constitutional issues, materially deviating from pure cash accounting in only three regards: ${ }^{166}$ (1) interest is accrued on public issues of Treasury debt, regardless of whether it is paid; ${ }^{167}$ (2) the subsidy cost of direct loans and loan guarantees

164. See, e.g., Thor Power Tool Co. v. Commissioner, 439 U.S. 522, 542 (1979) (stating that major responsibility of accountant is to protect management, shareholders, creditors, and others properly interested from being misled and that major responsibility of IRS is to protect public fisc).

165. By this I do not mean to suggest that outside review of a legislature's scorekeeping judgments would be unconstitutional under current law. To the contrary, in Bowsher v. Synar, 478 U.S. 714 (1986), the Court held that Congress's attempt to retain the scorekeeping function within the legislative branch, in the person of the Comptroller General, was an infringement on executive power. Nevertheless, it is clcar that Congress was concerned about reposing the scorekeeping function in the executive branch.

166. See OfFice of MANAGEMENT \& BUdGet, CirCular No. A-34, InStructions on BUdget EXECUTION II 21.1, at II-4 (Nov. 1994).

167. See DEPARTMENT OF THE TREASURY, supra note 20, at 335. Interest on special issues of debt securities held by trust funds and other Government accounts, by contrast, is normally recorded on a cash 
is accrued when the loans are disbursed; ${ }^{168}$ and (3) so-called cash equivalent transactions are treated as cash transactions. ${ }^{169}$ All three deviations are implemented through mechanical rules that do not require the exercise of any significant judgment.

We are faced, therefore, with a choice between, on the one hand, an inaccurate accounting method that permits circumvention, encourages distorted decisionmaking, and fails to protect the value of intergenerational equity but allows Congress to operate without outside review, and, on the other hand, an accounting method that can be made as accurate and effective as desired but requires an independent body to keep score. I will discuss the pros and cons of an independent scorekeeper later. Nevertheless, an effective, enforceable, politically nondistortive balanced budget amendment must use accrual accounting. The decision made in the 1995-96 Senate Draft to enshrine the cash method forever in the Constitution is wrong. ${ }^{130}$

\section{B. Scope of the Amendment}

A second problem in structuring and interpreting a balanced budget amendment is that of defining the entities or programs to which it applies. To the extent that Congress has the ability to move receipts into, or outlays and debt out of, an amendment's computations, it may meet the technical requirements of the amendment simply by redefining what is included in the budget, without making any real changes to receipts, outlays, or debt. The 1995-96 Senate Draft speaks in terms of receipts and outlays of "the United States Government"171 and imposes limits on "the debt of the United States held by the public." "? What is "the United States Government"? What is "debt of the United States"? What is "the public"? The answer to each of these questions is less certain, more complex, and more subject to manipulation than one might hope.

Current budgetary practice draws no distinction between the United States and so-called "government-owned corporations" like the Postal Service, the

basis. See id. In the case of debt purchased by the Military Relurement Trust Fund or the Educatton Benelits Trust Fund, however, the difference between purchase pnce and the par salue of the debt is amorized over the life of the debt. See id.

168. See id.

169. Debt instruments such as bonds. debentures. notes, or monelan credits are treated as cash for this purpose. See id. at 334. In addition, lease-purchase transactions are recorded as direct purchases Ser id at 334-35. Government deposits with the International Mionetary fund are treated as cash, as are holdings of foreign currency by the Exchange Stabilization Fund. See sd. at 337 Gold is treated as cash as well, and sales of gold are therefore treated as a means of financing. See id at 336

170. I do not here advocate the adoption of any paruculas form of accrual accounung The accrual method used for federal income tax purposes is clearly imperfect. See. e.g. GRAETZ \& SCHENK, supra note 107, at 713-14. In Section III.A below. I argue for the creation of an independent scorekeeper Implicit in this recommendation is that such a scorekeeper would adopt and refine accrual accounting rules sinuctured to protect the values the amendment is intended to further.

171. S.J. Res. 1, 104th Cong. $\$ 7$ (1995), reprimted in Appendix.

172. Id. §2. 
Resolution Trust Corporation, the Pension Benefit Guaranty Corporation, and the Government National Mortgage Association (more familiarly known as "Ginnie Mae"). ${ }^{173}$ Outlays and receipts of entities in both categories are consolidated in a single budget, analogous to a consolidated tax return or financial statement, known as the "Budget of the United States Government," which is subject to congressional control under the Appropriations Clause of the Constitution. ${ }^{174}$ The budgets of those entities not subject to congressional review and appropriation-including so-called "government-sponsored enterprises" like the Student Loan Marketing Association ("Sallie Mae"), the Federal National Mortgage Association ("Fannie Mae"), and the Federal Home Loan Mortgage Corporation ("Freddie Mac")-are treated as private entities ${ }^{175}$ and excluded from the budget. Thus the Federal Reserve System, although an agency of the United States, is excluded from the federal budget because its funds are exempt by statute from congressional review and appropriation. ${ }^{176}$

The consolidated budget of the United States government is broken into at least four types of funds: one general fund and a number of special funds, revolving funds, and trust funds. ${ }^{17}$ Whether the outlays and receipts of an administrative unit are accounted for through a given type of fund is not necessarily related to whether the unit is structured as an integral part of the United States or as a separate corporate entity. The general fund accounts for many core governmental activities: Its receipts include most income and excise taxes, and its outlays, many of the principal expenses of government, include interest on the national debt. ${ }^{178}$ Special funds (such as the Land and Water Conservation Fund) and trust funds (such as the Social Security trust funds) account for programs financed by collections from specific sources. ${ }^{179}$ Revolving funds-both "public enterprise" funds and intergovernmental funds-account for entities or programs that charge for the sale of goods or services. The Postal Service, which is a separate corporate entity, and the Federal

173. See DEPARTMENT OF THE TREASURY, supra note 20, at 330-31 (noting that budget includes all government entities except government-sponsored enterprises).

174. The Appropriations Clause provides: "No Money shall be drawn from the Treasury, but in Consequence of Appropriations made by Law; and a regular Statement and Account of the Receipts and Expenditures of all public Money shall be published from time to time." U.S. CONST. art. I, § 9, cl. 7.

175. See DEPARTMENT OF THE TREASURY, supra note 20, at 330 (discussing government-sponsored enterprises generally); DEPARTMENT OF THE TREASURY, BUDGET OF THE UNITED STATES GOVERNMENT, FISCAL YEAR 1997, APPENDIX 1129-45 (1996) (describing existing government-sponsored enterprises and their budgets).

176. See DePARTMENT OF THE TREASURY, supra note 20, at 330 . The System's net earnings, however, are transferred annually to the Treasury and recorded as receipts. See id.

177. See id. at 331. In addition, the budget includes so-called "credit program accounts," which record the subsidy cost of government loans and loan guarantees. As loans are disbursed, amounts are transferred from the appropriate credit program account to a nonbudgetary "credit financing account." Id. at 335-36. In effect, program accounts serve as budgetary reserves for loan outlays accrued but not paid under special budgetary rules for the accrual of loan program expenses.

178. See id. at 255 ; SCHICK, supra note 86 , at 14.

179. See DEPARTMENT OF THE TREASURY, supra note 20, at 255; SCHICK, supra note 86 , at 14. 
Buildings Fund, which is not, are both accounted for as revolving funds. ${ }^{180}$ Collections by revolving funds are treated as offsets to outlays, not as "receipts." As a result, only outlays net of collections are currently subject to budgetary control. ${ }^{181}$ All funds other than trust funds are known collectively as "federal funds"; trust funds are not included in this aggregation. ${ }^{182}$ Finally, three funds whose outlays and receipts are in fact reported as part of the budget are deemed "off-budget" by law: the Postal Service and the two Social Security trust funds. ${ }^{183}$ The government accommodates this paradox by including their outlays and receipts in the budget but labeling them "off-budget."18. The only outlays and receipts excluded from the budget are those of entities whose budgets are exempt from congressional review and appropriation. Somewhat confusingly, these entities are also sometimes referred to as "off-budget."

Consistent with this complexity, the government reports at least three annual deficit figures: the unified or consolidated deficit, the on-budget deficit, and the federal funds deficit. ${ }^{185}$ The deficit most commonly reported in news accounts is the unified deficit, which aggregates all budgetary outlays and receipts, including on-budget items deemed "off-budget" by law but not items actually excluded from the budget. Consistent with its name, the on-budget deficit excludes items deemed "off-budget" by law, that is, outlays and receipts of the Postal Service and the two Social Security trust funds. ${ }^{186}$ Because the Social Security system currently runs a large surplus, the on-budget deficit is currently much larger than the unified deficit. ${ }^{187}$ The federal funds deficit, finally, omits the outlays and receipts of all trust funds. ${ }^{188}$

On its face, the 1995-96 Senate Draft appears to track current budgetary practice. The balanced budget requirement of section 1 is applied by section 7 to the "United States Government,"189 a term that seems to refer to the same "United States Government" for which a budget is now enacted and published each year ${ }^{190}$-that is, the aggregate of all entities or programs whose budgets

180. See DePartment OF THE TREASURY, supra note 20. at 476 (Federal Buildings Fund). $t d$. at $\$ 93$ (Postal Service). Revolving funds are further divided into two categones: "public enterpnse funds." which are used to account for programs that conduct business-type operations. pnmanly with the public. in which outlays generate collections, and "intragovernmental funds," which are used to account for business-type operations within and between government agencies. See id. at 331.

181. See id. at $255,331-32$.

182. See id. at 331 .

183. See id. at 330 .

184. See SCHICK, supra note 86 , at 14.

185. See id. at 28-29. Two other deficits are generally reported: the operalung deficit. which excludes investment in physical capital, and the structural deficit, which estımates what the untied defictl would be if the economy were operating at 5.5\% unemployment. excluding the effects of extroordinary events such as the Persian Gulf War. See id. at 29-31.

186. See id. at 28.

187. See id.

188. See id. at $28-29$.

189. S.J. Res. 1, 104th Cong. $\$ 7$ (1995), reprinted in Appendix.

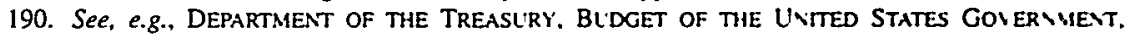
FISCAL YEAR 1996 (1995). 
are subject to congressional review and appropriation. The language of section 2, which applies to "debt of the United States held by the public," similarly invokes a phrase now used to refer to debt issued by those same entities or programs ${ }^{191}$ and held either by private investors or by entities or programs whose budgets are not subject to congressional review. ${ }^{192}$ Such a reading, combined with the modified cash method currently used by Congress, would target the "unified deficit." It would also make the balanced budget amendment coextensive with the Appropriations Clause, which, at least in theory, defines the boundaries of the current budget. ${ }^{193}$

Although facially attractive, adoption of the line used to define the scope of the Appropriations Clause to define the scope of a balanced budget amendment creates serious problems. First, Congress has asserted the power to determine by statute whether entities are subject to the Appropriations Clause. By statute, for example, the Federal Reserve System, a federal agency exercising quintessentially governmental powers, is exempt from the appropriations process, excluded from the budget, and counted as part of the "public" for purposes of measuring debt of the United States held by the public. ${ }^{194}$ As has been noted, the Resolution Funding Corporation was statutorily excluded from the budget to circumvent thenexisting balanced budget rules; its sole purpose was to incur off-budget debt to finance the Resolution Trust Corporation, which is on-budget. ${ }^{195}$ If a unitary standard were to be adopted for both the Appropriations Clause and a balanced budget amendment, and Congress's asserted power to define that standard were to be upheld or insulated from constitutional challenge, Congress would have the

191. The 1995 Committee Report states that ".debt of the United States held by the public . . . is a widely used and understood measurement tool. . . . The current, accepted meaning of 'debt . . . held by the public' is intended to be the controlling definition under this article." S. REP. No. 104-5, at 16 (1995). The report quotes the GENERAL ACCOUNTING OFFICE, supra note 104, which defines "debt held by the public" as "[t]hat part of the gross federal debt held outside of the federal government." $I d$. at 38. The term "gross federal debt" is then defined to include all public and agency debt. Public debt consists of debt incurred when the Treasury or the Federal Financing Bank borrows directly from the public or another fund or account. Agency debt includes debt of other budgetary entities and therefore does not include debt of "government-sponsored enterprises." $I d$. at 37 . The proposed debt ceiling rules thus differ significantly from the current statutory federal debt limit. Currently, the ceiling is not limited to debt held by the "public." In addition, not all Treasury debt is subject to the current limit; silver certificates and debt issued by tho Federal Financing Bank, a part of the Treasury Department, are not. See DEPARTMENT OF THE TREASURY, supra note 20, at 194. Moreover, all agency debt except debentures issued by the Federal Housing Administration is currently exempt. See id.

192. The 1995 Committee Report states: "'Debt Held by the Public . . . includes any federal debt held by individuals, corporations, state or local governments, the Federal Reserve System, and forcign governments and central banks. Debt held by government trust funds, revolving funds, and special funds is excluded from debt held by the public." S. REP. No. 104-5, at 16 (quoting General AcCOUNTING OFFICE, supra note 104).

193. The Appropriations Clause prohibits expenditures out of "the Treasury" without appropriation. See U.S. ConsT. art. I, § 9, cl. 7. The 1995 Committee Report states similarly: “. . . Total reccipts . . . is intended to include all moneys received by the Treasury of the United States . . . except those derived from borrowing. . . . . . Total outlays ...' is intended to include all disbursements from the Treasury of the United States ... except those for repayment of debt principal." S. REP. No. 104-5, at 19. The Tennessee Valley Authority, however, is intended to be off-budget for amendment purposes. See id.

194. See DEPARTMENT OF THE TREASURY, sipra note 20, at 331.

195. See supra note 162 and accompanying text. 
power to exempt outlays and debt from the limitations of a balanced budget amendment at will.

Solving this problem by permitting the courts to set a unitary constitutional standard for both the Appropriations Clause and a balanced budget amendment creates other difficulties. The current working definition of the scope of the Appropriations Clause may not be constitutionally sound. The statute that exempts the Federal Reserve System from congressional budgetary control, ${ }^{1 \%}$ for example, is difficult to reconcile with the Appropriations Clause. ${ }^{197}$ Defining the scope of a politically contentious balanced budget amendment by reference to current budgetary practice is likely to bring such constitutional issues to the fore. This might, in turn, force unanticipated changes in the structure of the federal government. Most worrisome is the possibility that the Federal Reserve System would lose control over its budget. If the Fed's budgetary independence contributes to the independence of its monetary policy from political influence, ${ }^{198}$ such a loss might compromise U.S. monetary discipline. In such an event, a balanced budget amendment would represent at best a Pyrrhic victory.

Even a constitutionally defined standard, however, is unlikely to prevent Congress from manipulating the limits of the amendment if the same line is used for both Appropriations Clause and balanced budget purposes. The courts have long held that money genuinely held in trust by the United States is not "public money" subject to appropriation or budgetary control. ${ }^{199}$ Whether money is held in trust is, in turn, a question of property law subject to statutory resolution. Adoption of the Appropriations Clause line for balanced budget purposes would therefore allow Congress to insulate programs from a balanced budget amendment's limitations simply by converting such programs to trust form. Currently, no programs subject to appropriation are so structured. "Trust funds" are not trusts in the conventional sense; all moneys held by such funds are the

196. See 12 U.S.C. $\$ 244$ (1994) (“[F]unds denved from such ussessments shall not be construed to be Government funds or appropriated moneys.").

197. See U.S. CONST. art. I, \$ 9, cl. 7. Both the Comptroller General and the Altomes General have opined that Federal Reserve funds are "public moneys." See 3 Comp. Gen. 190. 192-93 (1924). 30 Op Att'y Gen. 308, 309-10 (1919).

198. It is not clear whether financial independence is necessary for the effectuve functionung of a

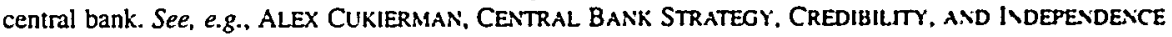
(1992) (describing benefits of central bank independence and developing proxy vanables for such independence). The Federal Reserve System's authorizing statules, however, do evidence Congress's belief that such independence is important. See CONGRESSIONAL BLDGET OFFCE. TUE BLDCETARY STATL'S OF THE FEDERAL RESERVE SYSTEM at xiii (Feb. 1985) ("This insulated budgetary status has enabled the Federal Reserve to make decisions with relauve independence from Congressional and Presidentral influence."); SUBCOMM. ON GENERAL CREDIT CONTROL AND DEBT MIANAGENENT OF THE JOINT COMN ON THE ECONOMIC REPORT, 82D CONG.. MONETARY POLICY AND THE MANAGEMENT Of THE PLiLIC DEBT 62 (1952) (expressing fear that "if the Federal Reserve Sysiem were subjected to standard appropnation procedure-with all the structural changes in the System which this would imply-the role of monetary policy in the economic affairs of the Government would inevitably be curtaled and an important buiwark against infiation would be weakened").

199. See, e.g., United States v. Ten Thousand Dollars in U.S. Currency, 860 F.2d 151!. ISI 4 (9ih Car. 1988); Emery v. United States, 186 F.2d 900, 902 (9th Cir. 1951): Vamey v. Warehume, 147 F 2d 238, 245 (6th Cir. 1945); United States v. Rogers, 81 F. 941.943 (9th Cir. 1897). 
property of the government. ${ }^{200}$ Congress could, however, convert many such programs into genuine trusts. For example, Congress might declare that Social Security funds are not government property but are held in trust for future beneficiaries; the result would be to take Social Security off-budget, ${ }^{201}$ exclude Social Security premiums from "receipts" for balanced budget purposes, and exempt Social Security benefits from any cuts required in the event of a government deficit.

It may also prove difficult to define a unitary constitutional standard that prevents manipulation of the line between government-owned and governmentsponsored corporations. In general, entities owned in part by the government are currently treated as part of the government; entities in which the government has no equity interest are not. ${ }^{202}$ Even if such a rule were constitutionalized, all Congress would have to do to place an entity off-budget would be to authorize it to issue stock to private shareholders and create incentives for the purchase of such stock.

At least in the context of the 1995-96 Senate Draft, the 1995 Senate committee report creates a further obstacle to the adoption of a unitary standard. Apparently to reassure affected constituencies, the report states:

Among the Federal programs that would not be covered by S.J. Res. 1 is the electric power program of the Tennessee Valley Authority. Since 1959 , the financing of that program has been the sole responsibility of its own electric ratepayers-not the U.S. Treasury and the Nation's taxpayers. Consequently, the receipts and outlays of that program are not part of the problem S.J. Res. 1 is directed at solving. ${ }^{203}$

200. See DEPARTMENT OF THE TREASURY, supra note 20, at 331 (contrasting use of term for federal budgetary purposes with general legal usage).

201. Whether Social Security should be part of the budget subject to any balanced budget amendment has been the subject of considerable controversy. See, e.g., H.R. REP. No. 104-3, at 28-30 (1995) (dissenting views) (asserting that balanced budget amendment will place Social Security at risk). In 1995, several senators stated that they would have voted for the 1995-96 Senate Draft if Social Sccurity had been removed from the budget for amendment purposes. See, e.g., 141 CONG. REC. S3514 (daily ed. Mar. 6 , 1995) (statement of Sen. Boxer). Removal would have at least three consequences. First, any excess of Social Security receipts over Social Security expenditures would not be available to mask larger deficits in other parts of the budget; in the short run, the deficits subject to the amendment would appear much larger. Second, cutting Social Security expenditures would not cut the reported deficit; Social Security expenditures would thus be effectively immune from any remedial action imposed as a result of the amendment. Finally, the amendment would not require that the Social Security program itself be run in a manner consistent with institutional responsibility, intergenerational equity, and economic prudence. For those concerned about Social Security benefits, the worst result would be for Social Security to remain onbudget for amendment purposes until the program itself goes into deficit (permitting Social Security receipts to mask deficits elsewhere and Social Security cuts to constitute budget-balancing) and then moved offbudget for amendment purposes and be self-funding thereafter.

202. See DEPARTMENT OF THE TREASURY, stupra note 175, at 1129-45 (describing structure and operations of current government-sponsored enterprises); A. Michael Froomkin, Reinventing the Government Corporation, 1995 U. ILL. L. REv. 543, 547-48, 554-55 (contrasting wholly-owned and mixed-ownership government corporations).

203. S. REP. No. 104-5, at 19 (1995). 
The TVA is an on-budget instrumentality of the United States Government, accounted for as a revolving fund subject to the Appropriations Clause, which has recently (notwithstanding the report's suggestion to the contrary) run a deficit of between $\$ 500$ million and $\$ 1$ billion per year. ${ }^{204}$ If the foregoing 1995 Senate committee report language were given effect, the 1995-96 Senate Draft and the Appropriations Clause cannot be coextensive.

Articulating a general principle that would exempt the TVA, but not other government programs, from the 1995-96 Senate Draft is a difficult task. By definition, all revolving funds are financed by business-type activities, except to the extent of deficits. ${ }^{205}$ One reading of the quoted language in the 1995 Senate committee report might be to exempt all revolving funds, or at least all "public enterprise" funds, from the amendment. Transfers from the general fund to cover revolving fund deficits would constitute "outlays," but revolving funds themselves could nevertheless borrow for their own accounts without such debt constituting "debt of the United States." Any such construction, however, would open major holes in the amendment. The current budget contains scores of both "public enterprise" funds, which conduct business operations primarily with the public, ${ }^{206}$ and "intragovernmental" funds, which conduct business operations

204. See DePaRTMENT OF THE TREASURY, supro note 20, at 495.

205. See id. at 331.

206. See id. at 385-500. Government entities accounted for completely or promanly as "public enterprise" funds include the National Technical Information Serite. the William Langer Jewel Bcanng Plant, the Helium Fund, the Pension Benefit Guaranty Corporation. the Saint Lawrence Seaway Development Corporation, the Exchange Stabilization Fund, the Office of Thrift Superviston, the Farm Credit Administration, the Farm Credit System Insurance Corporation. the Federal Deposit Insurance Corporation, the Federal Housing Finance Board, the National Credit Union Adminstration, the Panama Canal Commission, the Postal Service, the Resolution Trust Corporatıon. the Tennessee Valley Authonty. and the U.S. Enrichment Corporation Fund. See id.

Less well-known "public enterprise" funds include the Agency for Intemational Deselopment's Property Management Fund; the Military Sales Program's Special Defense Acquisition Fund. the Graun Inspection, Packers and Stockyards Administration's inspection and weighing services, the Farm Service Agency's Federal Crop Insurance Corporation and Commodity Credit Corporation Funds; the Rural Uulıties Service's Rural Communication Development Fund liquidaung account: the Rural Business and Cooperanve Development Service's Altemative Agricultural Research and Commercialızatıon Revolving Fund. the National Oceanic and Atmospheric Administration's Coastal Zone Management Fund and Damage Assessment and Restoration Revolving Fund: the Defense Deparmeni's Homeowners Assistance and National Defense Stockpile Transaction Funds; the Office of Postsecondary Education's College Housing Loans program; the Energy Department's Isotope Production and Distribution Program Fund: the Food and Drug Administration's revolving fund for cerification and other services: the Health Resoures and Services Administration's Health Loan Fund; the Health Care Financing Administration's Health Maintenance Organization Loan and Loan Guarantee Fund; the Housing and Urban Development Deparment's low-rent public housing loans, Community Planning and Development Revolving. Rental Housing Assistance, Fexible Subsidy, and Homeowners Assistance Funds: the Bureau of Reclamatton's Lower Colorado River Basin Development Fund; the Federal Railway Administration's Ratroad Rehabilitation and Improvement Liquidating Account: the Federal Aviation Administratıon's Aviatıon Insurance Revolving Fund; the Maritime Administratıon's Vessel Operattons and War Risk Insurance Revolving Funds; the U.S. Mint's Public Enterprise Fund: the Internal Revenue Service's Federal Tax Luen Revolving Fund; the Veterans Health Administration's Medical Facılitues and Canleen Service Revolving Funds, Special Therapeutic and Rehabilitation Activities Fund, and medical center research organizations. the Veterans Benefits Administration's Service-Disabled Veterans Insurance. Veterans Reopened Insurance. and Servicemen's Group Life Insurance Funds: the Veterans Affars Deparment's Parking Garage Revolving Fund; the Environmental Protection Administration's Reregistration and Expedited Processing 
primarily within and between government agencies. ${ }^{207}$ In addition, many funds currently classified as special funds or trust funds could probably be converted into revolving ones. Social Security, for example, could be recast as a public enterprise fund engaged in the business of providing retirement insurance to working Americans.

If neither a line coextensive with the Appropriations Clause nor the line implied by the foregoing language in the 1995 Senate committee report is workable, how should the boundaries of a balanced budget amendment be defined? An approach sometimes used by states with constitutional balanced budget provisions is to exclude any entity whose debt is not secured by the general credit of the state from the scope of balanced budget computations. ${ }^{208}$ The state experience in this regard provides little basis for optimism; the principal consequence of such a rule seems to be higher overall interest costs, not an effective cap on borrowing. ${ }^{209}$ Applying the same rule to section 2 of the 1995-96 Senate Draft, however, would result at best in a patchwork system, since the debt of many on-budget entities is not secured while the debt of some offbudget entities is. ${ }^{210}$

In any event, such a line would be relatively easy to circumvent. Consider the following transaction: Congress creates a new off-budget entity, which I will call the National Parks Authority, contributes the minimum cash necessary to make the Authority creditworthy, say $\$ 20$ billion, and grants the Authority a secure source of revenue. The Authority buys the national parks from the United States for $\$ 100$ billion, raising the remaining $\$ 80$ billion by issuing bonds to the public and using the parks as collateral. The Authority then operates the parks as they have always been operated, using its secure source of revenue to service the debt. In reality, Congress has merely borrowed against existing government assets. Because the Authority is an off-budget entity whose debts are not secured by the general credit of the United States, however, it is treated as private for budgetary accounting purposes. As a result, the price paid for the parks is treated as a "receipt" deemed to contribute toward a balanced budget, and the new debt is exempt from budgetary limitations. This technique, commonly known as securitization, is only one of a number of sophisticated approaches to credit enhancement commonly used in the private sector, each of which would create

Revolving Fund; the General Services Administration's Consumer Information Center Fund; the Small Business Administration's Surety Bond Guarantees Revolving Fund; the Federal Emergency Management Agency's National Insurance Development and National Flood Insurance Funds; and the Pennsylvania Avenue Development Corporation's Land Acquisition and Development Fund. See id. If the budgets of all other such public enterprise funds were excluded, a balanced budget amendment would be porous indeed.

207. Most of the Government's current intragovermmental funds are used for purposes of intemal administration. A few, including Federal Prison Industries, Inc., the Federal Financing Bank, and the Bureau of Engraving and Printing, exist as separate entities. See id. at 428-29, 450.

208. See, e.g., HEINS, supra note 11, at 13-27 (reviewing role of nonguaranteed state debt).

209. See id. at 36-81 (discussing additional interest and other costs associated with nonguaranteed borrowing).

210. See SCHICK, supra note 86 , at 16. 
yet another possible avenue for circumvention of a balanced budget requirement. ${ }^{211}$

More work needs to be done on defining the boundaries of any amendment. One possible approach might be to define as part of the government any entity subject to effective control by federal appointees. ${ }^{2 ! 2}$ The successful implementation of this or any other line, however, is likely to require some degree of outside review. If Congress retains unsupervised control over the scope of the amendment, abuses are likely regardless of the line chosen.

\section{When to Test}

The question of when to test involves similar trade-offs. If the test is applied during the legislative process, it will constrain that process directly; if applied later, the amendment cannot directly limit congressional action. In addition, the later the test is applied, the harder it will be to remedy noncompliance; eventually a point will be reached where effective remedial action is impossible. An effective amendment will test the projected consequences of congressional action during the legislative process itself, so as to encourage congressional adherence to the values the amendment is supposed to protect. This will require that estimates be made of the likely budgetary consequences of proposed action, which will in turn require the exercise of judgment and, to prevent circumvention of the amendment. independent review of that judgment. The alternative, a test applied only when money is actually received and spent, eliminates the need for outside review but permits Congress to continue to act irresponsibly, limits remedial options, and may ultimately reduce Congress's participation in the formulation of a remedy.

The problem arises because there is generally a delay between congressional action and any resulting effect on the deficit. Current federal budgetary procedures are built around three concepts: budgetary authority, obligations, and outlays. $^{213}$ Congress votes on budgetary authority. A grant of budgetary authority authorizes an agency to incur obligations; that is, to purchase goods or services, enter into contracts, or undertake other actions that may result in a claim for payment. The actual payment is called an "outlay." Incurring obligations and making outlays are generally executive, not legislative, functions.

Outlays are not necessarily made in the year in which budgetary authority is voted. When Congress authorizes the purchase of an aircraft carrier, for example, the contract may not be signed until a subsequent year, and payments to the shipbuilder are likely to be spread over many years; their timing may depend on factors beyond the control of the government. In any fiscal year, therefore, the

211. For a general discussion of securitization techniques, see Joseph C. Shenker \& Anthony J. Colletta, Asset Securitization: Evolution, Current Issues and New Frontiers, 69 TEX. L. REV 1369 (1991).

212. See Froomkin, supra note 202, a! 630-31 (proposing aetual control as test for vanety of purposes, apparently including budgetary purposes).

213. See DePARTMENT OF THE TREASURY, supra note 20, at 333-35: SCHICK, supra note 86, at 19-20 
government normally spends only part of the budgetary authority approved for that year; all or part of the remainder may be carried forward to future years. At the same time, the government may spend part of the budgetary authority carried forward from prior years. ${ }^{214}$

In addition, a substantial portion of government spending is subject to socalled "permanent" appropriations: budgetary authority enacted for more than one year and often indefinitely. For example, Congress has given the executive branch permanent authority to make interest payments on the national debt. ${ }^{215}$ Spending programs subject to permanent appropriation, which currently include Social Security, Medicare, veterans' pensions, welfare, and farm subsidies, among others, are referred to as "direct," "nondiscretionary," or "mandatory" spending or, sometimes, as "entitlements"; spending subject to annual appropriation is called "discretionary spending."216 The projected cost of permanent appropriations, absent a change in law, is called the "baseline."217 A law reducing permanent appropriations does not necessarily reduce spending; it may merely reduce the rate of projected increase in spending. Nevertheless, it represents an affirmative decision of Congress to reduce what it had previously authorized to be spent. On the revenue side, taxes are generally imposed and collections authorized by permanent, rather than annual, legislation. Revenues for a particular year cannot be predicted with perfect accuracy because they almost always depend, in part, on factors outside the control of the government, such as taxpayer behavior or the state of the economy.

The delay between congressional action and its effect on receipts and outlays creates two problems. First, a budget approved by Congress for a given fiscal year requires that revenues and budgetary authority defined other than in dollar terms be estimated. The choice of estimating techniques can determine whether that budget is projected to meet a given fiscal target. For example, a technique that assumes that a tax cut will stimulate the economy, thereby triggering economic growth, may lead to the conclusion that such a tax cut will result in an increase in revenue. This technique, sometimes known as "dynamic scoring," allows a tax cut to be scored as a tax or, more accurately, revenue increase. Such scoring permits Congress to cut taxes, increase spending, and "balance" the budget, all at the same time. ${ }^{218}$

214. See DEPARTMENT OF THE TREASURY, supra note 20, at 333-35 (describing relationship between authority, obligations, and outlays); SCHICK, supra note 86, at 19-21 (same).

215. See 31 U.S.C. \& 3123 (1994).

216. See DEPARTMENT OF THE TREASURY, supra note 20, at 327. Estimates of the relative sizes of different types of federal spending are given infra text accompanying notes 289-97. It will be seen that permanent appropriations comprise a relatively large portion of all appropriated expenditures.

217. See CONGRESSIONAL BUDGET OfFICE, supra note 46, at 149 ("[B]aseline: A benchmark for measuring the budgetary effects of proposed changes in federal revenues or spending. As specified in the Budget Enforcement Act of 1990 (BEA), the baseline for revenues and entitlement spending generally assumes that laws now on the statute books will continue."); SCHICK, supra note 86, at 20-24 (describing role of baseline projections in budget process)

218. See, e.g., 1995 Joint Hearings, supra note 2, Part I, at 7, 9 (statement of Sen. Kyl) (asserting that 
A second issue is the choice of period over which to measure the effects of a given proposal. Even if conservative techniques are used to estimate projected receipts and outlays, the choice of period can dramatically affect the estimators' conclusions. The "Contract With America," for example, proposed a new system of depreciation for equipment placed into service after 1994. ${ }^{219}$ For short-lived equipment, the new system was somewhat less generous than existing law; for longer-lived equipment, however, it was far more generous. As a result, estimators projected an $\$ 18$ billion revenue increase during the first five years and a $\$ 139$ billion revenue loss during the next five, with revenue losses exploding even more thereafter. ${ }^{220}$ For budget balancing purposes, Congress focused only on the first five years and was therefore able to score this tax cut as a significant revenue increase, permitting additional tax cuts in other areas. If Congress controls scorekeeping rules, skillful use of estimating techniques and periods may allow it effectively to circumvent the spirit of any balanced budget requirements.

Under the 1995-96 Senate Draft, no estimation is required, but the only relevant year is the current fiscal year. Because section $I$ is framed in terms of actual, not authorized, outlays and receipts and section 2 in terms of limits on borrowing, the need for which arises only when money is actually spent, compliance is tested when money is spent, not when spending is authorized. The 1995 Senate committee report then goes further, explaining that compliance with section 1 is to be tested only retrospectively for the year as a whole. ${ }^{221}$ This means that the test cannot be performed until the year has closed, at which time, the report reassures its anxious senatorial readers, it will be too late for anyone

tax cut can generate more revenue): 1995 House Hearings. supra note 2. a1 234. 236 (statement of Charles J. Whalen, Resident Scholar, Jerome Levy Economics Institute) (discussing dy namic sconng). Bruce Barlett, The Case for Dynamic Scoring. WALL ST. J. EUR.. July 3!. 1996. at 6 (asserting that dynamie scoring is warranted); Martin Feldstein, Board of Contributors: The Case for Dynamtc Analysis. WaLL ST J., Dec. 14, 1994, at A14 (arguing that dynamic scoring is necessan). But see Keeping Score on the Budget, N.Y. TIMES, Dec. 5, 1994, at A18 (criticizing Republican proposals for dynamic sconng): Peicr Passell, Some Creative Ways Republicans Could Deliver on the Contract, N.Y. TIVES. Nov 17. 1994, at $\mathrm{D} 2$ (discussing dynamic scoring as way of fudging numbers); Laum D'Andres Tyson. Dynomic Scorng: Not Ready for Prime Time, WALL ST. J., Jan. 12, 1995, at Al4 (critiquing Bartlett and Feldstetn positions). For more extensive discussions of the problem. see Michael D. Bopp. The Roles of Revenue Estumation and Scoring in the Federal Budget Process, TAX NOTES TODAY, Sept. 24, 1992, avaluble in LEXIS. Taxana Library, TNT File, 92 TNT 194-108; Jane G. Gravelle. Can a Capual Gains Tax Cut Pay for liself. TAX NOTES TODAY, Mar. 23, 1990, available in LEXIS, Taxana Librar. TNT File. 90 TNT 131-9: Roben D. Reischauer, Budget Estimates: Current Practices and Alternative Approaches. CBO Report for Joint Hearing of House and Senate Budget Committees. TAX NOTES TODAY. Jan. II. 1995. avallable in LEXIS. Taxana Library. TNT File, 95 TNT 7-16; Robert D. Reischauer. Effects of Lower Capual Gains Tuxes on Economic Growth, TAX NOTES TODAY, Aug. 31. 1990, available in LEXIS. Taxana Library. TNT File, 90 TNT 181-1.

219. See House Republican Conference Legislative Digest, Tax Faimess and Deficur Reduchon Act. H.R. 1215, TAX NOTES TODAY. Mar. 28, 1995, available in LEXIS. Taxana Library. TNT File. 95 TNT 67-53.

220. See Alber J. Davis, Budget Implications of Contract with America Tax Curs, TAX NOTES TODAY. May 8, 1995, available in LEXIS. Taxana Library. TNT File. 95 TNT 91-89. Davis notes that the full revenue losses from the proposed depreciation system would not appear for aboul 30 years. Overall. he notes, the tax package is projected to lose $\$ 189$ billion during the first five years (the period counted for budget-balancing purposes) but another $\$ 452$ billion in the following five years. See id.

221. See S. REP. NO. 104-5, at 10-11 (1995). 
to impose a remedy if Congress has not already complied voluntarily. ${ }^{222}$ Under either reading, compliance is not tested and therefore is not required at any time during the legislative process. As a result, the draft imposes no direct limitation whatsoever on legislative action. Its controls, to the extent that they are enforceable at all, are imposed instead on an executive activity-the spending itself. ${ }^{223}$

The Draft thus avoids the problems inherent in estimation. It does so, however, at the cost of extreme short-sightedness. So far as the amendment is concerned, nothing projected to occur beyond the end of the current fiscal year matters. As a result, the Draft does not prohibit prospective tax cuts or spending increases, no matter how extravagant. Admittedly, all chickens eventually come home to roost. In the meantime, however, Congress may act as irresponsibly as it wishes, dispensing future tax cuts and committing the government to future spending with wild abandon.

\section{Accommodating Fiscal Policy}

The final problem is accommodating macroeconomic concerns. Here, the problem is not primarily one of potential circumvention but rather how to implement what is, in part, a macroeconomic constitutional provision in ways that make economic sense. As has been noted, an amendment that fails to address this problem may require unnecessarily painful transitions, aggravate recessions or depressions, and eliminate the budget's current countercyclical stabilization function. Unfortunately, no formulaic adjustment has yet been suggested that resolves all these issues satisfactorily.

One obvious economic inaccuracy of most proposed deficit measures is their failure to adjust for inflation. ${ }^{224}$ Such an adjustment can radically alter conclusions as to the size of the deficit problem. ${ }^{225}$ Assume, for example, that the national debt at the beginning of the year is $\$ 5$ trillion. Over the course of the year, the government runs a $\$ 200$ billion nominal deficit and borrows the extra $\$ 200$ billion. At the end of the year, the national debt is therefore $\$ 5.2$ trillion. Assume, however, that inflation for the year is $5 \%$. In inflation-adjusted dollars, therefore, the national debt at the end of the year is only $\$ 4.95$ trillion. In other

222. See id.; infra notes $250-51$ and accompanying text.

223. The many substantive problems (and few benefits) that flow from this decision will be discussed infra Section II.D.

224. See, e.g., COX ET AL., supra note 41, at 22; cf. CONGREsSIONAL BUdGET OfFICE, THE FEDERAL DEFICIT: DOES IT REALLY MEASURE THE GOVERNMENT'S EFFECT ON NATIONAL SAVINO? 15-19 (1990).

225. See generally ROBERT EISNER, HOW REAL Is THE FEDERAL DEFICIT? 9-25 (1986) (discussing "tricks played by inflation"); William G. Dewald, CBO and OMB Projections, Adjusted for Inflation, Show Federal Budget Deficit Under Control, EcoN. Rev. (Federal Reserve Bank of Richmond), Nov.-Dec. 1985. at 15,17 (illustrating how failure to adjust budget for inflation makes standard measures of deficit deceptive). 
words, the real debt has gone down, not up. In real terms, the government has run a $\$ 50$ billion surplus, not a $\$ 200$ billion deficit. ${ }^{226}$

Congress has long recognized the need to make inflation adjustments to other financial measures. ${ }^{227}$ Other economic indicators are generally inflation-adjusted. For those attempting to set fiscal policy, this difference may be vitally important. Indeed, some economists have argued that when inflation is accounted for, fiscal policy has a much larger effect on the economy than has been acknowledged.22s Such a conclusion, if confirmed, might provide an additional argument for controlling the deficit thus defined. ${ }^{229}$ Even so, such an adjustment would not, by itself, solve the problems of transition, downturn, and countercyclical stabilization. ${ }^{230}$

Another possible adjustment would account for changes in levels of economic activity. ${ }^{231}$ A deficit caused by recession is arguably less troubling than one caused by congressional irresponsibility. A balanced budget amendment should attempt to control the latter, not the former. In addition, an amendment incorporating an adjustment for economic conditions may be structured to require a balanced budget over the business cycle, not merely over an economically arbitrary fiscal year. This may, at least partially, accommodate the problem of downturns and continue to permit the federal government to play a countercyclical stabilizing role.

Perhaps with these possibilities in mind, the Treasury separates the nominal deficit into two parts, the so-called "cyclical deficit," which reflects the lower receipts and higher expenses that occur automatically whenever there is slack in the economy, and the "structural deficit," an estimate of what the deficit would be if the economy were operating at full employment. ${ }^{232}$ The effect of requiring a balanced structural deficit would be to permit a nominal deficit during recessions and require a nominal surplus during periods of full employment.

226. In effect, inflation is a tax imposed on the holders of dollar-denomunated govemment debt in the hypothetical in the text the debt is worth $\$ 250$ billion less, in real terms. at the end of the year and the government, again in real terms, is $\$ 250$ billion wealthier. The "receipls" from this "tax" convert a \$200 billion deficit into a $\$ 50$ billion surplus.

227. See, e.g., I.R.C. $\$ \S 1(\mathrm{f}), 29(\mathrm{~d})(2)(\mathrm{B}), 32(\mathrm{j}), 43(\mathrm{~b})(3), 45(\mathrm{~d})(2)(\mathrm{B}), 45 \mathrm{~A}(\mathrm{c})(3), 63(\mathrm{c})(\mathrm{d}), 68(\mathrm{~b})(2)$, 132(f)(6), 135(b)(2)(B), 7872(g)(5) (1996).

228. See EISNER, supra note 225, at 1-8; JOHN H. MAKIN, L'S. FISCAL POLICY ITS EFFECTS AT HOME AND ABROAD 4-6 (1986).

229. I do not here advocate the adoption of an adjustment for infiation. In Section II.A. I argue for the creation of an expert independent scorekeeper. Implicit in this recommendation is that such a body would examine the issue of appropriate adjustments and promulgate rules best structured to protect the values the amendment is intended to further.

230. See MAKIN, supra note 228, at 4-5.

231. See DePARTMENT OF THE TREASURY, supra note 20, at 10-11 ("Changes in the sinuciural deficil give a better picture of the impact of budget policy on the cconomy than does the unadjusted deficit."). SCHICK, supra note 86 , at 30-31 (assering that structural deficit is "useful in distinguishing between deficits due to the performance of the economy and those due to govemment policy").

232. See Congressional BudGet OfFice, supra note 46, at 99-111: DepartMeit of the TREASURY, supra note 20, at 10-11: SCHICK, supra note 86. at 30-31. 
Some have gone further to argue that the target should be a balanced inflationadjusted structural deficit. ${ }^{233}$

Even the most sophisticated such formula, however, will probably never be fully satisfactory. No formula deals well with the problem of transitions: how to move without undue pain from an unbalanced budget to one that complies. It is also likely that no formula, however sophisticated, will deal with economic downturns and the business cycle as well as informed judgment might. In addition, all such formulae reflect a still developing economic science; it would be premature to constitutionalize even the most sophisticated exemplar.

The 1995-96 Senate Draft responds to these problems by ignoring them. It attempts to control what economists sometimes call the "nominal deficit"- that is, the deficit unadjusted for inflation or variations in economic conditions. The Draft requires Congress to implement a contractionary fiscal policy during recessions and permits Congress to implement an expansionary fiscal policy during periods of rapid economic growth, thereby amplifying both extremes of the business cycle. Absent a supermajority vote in both houses, the Draft apparently even prohibits running a deficit in a full-fledged economic depression, regardless of how deep. And it requires an immediate and abrupt return to budgetary balance at the conclusion of those events that do permit temporary deficits, regardless of their size.

None of these results is necessary to implement the values underlying the amendment. Each is inconsistent with economic prudence. The approach taken by the 1995-96 Senate Draft instead reflects both a concern that Congress lacks the institutional competence to make fine macroeconomic judgments and a reluctance to permit external involvement in administering the amendment. In other words, it again evidences a tension between outside review and effective administration. So viewed, the problem of accommodating fiscal concerns may be amenable to the same type of solution as the prior three problems discussed in this Part. As I will discuss in Section III.A, an independent scorekeeper could be authorized to set annual numeric budgetary targets, taking into account both the values underlying the amendment and the condition of the economy.

\section{HOW TO GET THERE}

Although the problem of enforcement has received far more consideration than the problem of defining the budgetary target, it has resisted satisfactory solution. Two issues have dominated the debate: judicial enforcement and presidential impoundment. Judicial enforcement involves the possibility that a court would determine that a budgetary target has not been met and order a remedy-e.g., spending cuts or tax increases. Presidential impoundment involves

233. See Robert Eisner \& Paul J. Pieper, A New View of the Federal Debt and Budget Deficirs, 74 AM. ECON. REV. 11, 11 (1984). 
the possibility that the President would make the same determination and refuse to spend appropriated moneys. Both solutions have troubled Congress and commentators.

Much ink has been spilled over issues raised by, but ultimately tangential to. the problem of judicial enforcement: whether, under existing law, courts could hear such a case and whether, again under existing law, courts could order a remedy. ${ }^{234}$ These questions, while important in some respects, are largely irrelevant to drafting enforcement solutions, since a constitutional amendment may change existing law to resolve such problems. The relevant question is the substantive one: Should courts determine whether the numerical standards imposed by the amendment have been met and fashion a remedy if they have not? Opponents of judicial enforcement have argued that cours lack institutional competence to make such decisions, should not be asked to set priorities among spending programs, and should not have the power to raise taxes. ${ }^{235}$ Allowing the courts to fashion a remedy, they asser, would radically shift the balance of power. ${ }^{236}$ Proponents have responded that if the political branches cannot balance the budget, the courts offer the only real hope..$^{3.77}$ At the same time, they have attempted to meet opponents' concerns by suggesting restrictions on the scope of permitted judicial review. ${ }^{238}$ Congress has also expressed concern over the possibility that a balanced budget amendment would be construed to authorize presidential impoundment. ${ }^{239}$ The power of the purse is one of Congress's most

234. See, e.g., Bowen, supra note 6. at 565 (dealing with standing and politucal question doctrne). Tobin, supra note 6, at 185-92 (same): Crosthwatt, supra note 6. al 1071-89 (same). Stase Euperterne. supra note 6, at 1610-15 (dealing with political question doctnne)

235. See, e.g., 1995 House Hearings, supra note 2, at 17 (statement of Charles L Schulte. Sentor Fellow, Brookings Institution) (noting problem of judges mahing tax and spending decistons). id at 59) (statement of Rep. Schaefer) (same); id. (statement of Rep. Conyers) (same); Id. at 180 (statement of Jefifre) N. Wennberg, Mayor. Rutland, Vermont) (same); id. at 227 (statement of William Dellinger. Assistani Attomey General, Department of Justice) (same): 1994 Senate Judician Comm. Hearmg. supra nole 2, al 80 (statement of Griffin Bell, former Attomey General. Depanment of Justuce) (same). 1933-\$4 Senate Hearings, supra note 2, at 82 (statement of Professor Robert D. Goldstein) (same). id. at 260 (statement of Professor George D. Brown) (same); id. at 281 (statement of Archibald Cox. Charman. Common Cause) (same); H.R. REP. No. 104-3, at 35 (1995) (dissenting views) ("The most fnghtening seenano to many taxpayers is court-ordered tax increases. And the specter of court-ordered budget cuts or automatic sequestration of funds in the middle of a fiscal year is no less likely. or disturbing."). id. at \$0-42 (additional views) ("The resolution reallocates one of Congress" core functions-federal budgetan priorities-to the Judicial Branch."); Rodino, supra note 6, at 801 (noung that courts do not have staffs of budgetary experts and that budgetary decisions are inherently legislatue because they involve reconciliation of competing priorities).

236. See, e.g., Crosthwait, supra note 6, at 1090-103 (noting unprecedented iniruston upon coequal branches); State Experience, supra note 6. at 1610-15 (arguing that granting courts power of enforeement would distort balance of power).

237. See, e.g., 1995 Joint Hearings, supra note 2, at 38 (statement by Sen. Mack) (masntainung that court enforcement may be necessary); 1995 House Hearings, supro note 2, at 67 (statement of Willtam P. Barr, Former Attorney General. Department of Justice) (arguing that judicial intervention would be ven limited); 141 CONG. REC. H754 (daily ed. Jan. 26, 1995) (statement of Rep. Schaefer) (claıming that courts could make only limited range of decisions): Bowen, supra note 6, at 618 (endorsing view that courts could and should fashion appropriate relief).

238. See, e.g., S.J. Res. 1, 104th Cong. $\$ 6$ (1995), reprinied in Appendix.

239. In the absence of such authorization, the President lacks the power to impound lawfully appropriated funds. See American Fed'n of Gov't Employees v. Phillips. 358 F. Supp. 60. 75 (D D C 
important powers. ${ }^{240}$ Impoundment, it is argued, would shift the balance of power in favor of the executive, without any check on the executive's exercise of that power. ${ }^{241}$

The 1995-96 Senate Draft, as elaborated in the 1995 Senate committee report, solved both of these problems by purporting to reserve almost all enforcement power to Congress itself. Senate Joint Resolution 1, as originally introduced, left open the question of judicial enforcement. The 1995 Senate committee report justified this silence with an exercise in studied ambiguity: "By remaining silent about judicial review in the amendment itself, its authors have refused to establish congressional sanction for the Federal courts to involve themselves in fundamental macroeconomic and budgetary questions, while not undermining their equally fundamental obligation to 'say what the law is ...."242 The report proceeded to argue that members of Congress should not fear judicial review because: (1) no one would have standing to bring suit under the amendment; ${ }^{243}$ (2) even if someone had standing, the "political question" doctrine would preclude judicial involvement; ${ }^{244}$ (3) even if courts heard the case, respect for Congress would preclude judicially ordered remedy ${ }^{245}$ and (4) even if courts intervened and ordered a remedy, Congress could statutorily deny courts the power to do so. ${ }^{246}$ When these arguments failed to persuade a sufficient number of senators, the following sentence was added to section 6 of the Draft: "The judicial power of the United States shall not extend to any case or controversy arising under this Article except as may be specifically authorized by legislation adopted pursuant to this section."247 In its final version, therefore, the 1995-96 Senate Draft purported to give Congress complete control over the scope of judicial review.

The Senate was equally unwilling to cede enforcement power to the President. Section 1 of the draft, read literally, prohibits outlays in excess of receipts. ${ }^{248}$ Since outlays are made primarily by the executive branch, this

1973). It is possible that a balanced budget amendment would change this conclusion. See, e.g., Judy v. Schaefer, 627 A.2d 1039, 1040 (Md. 1993) (holding impoundment necessary to carry out purposes of state balanced budget requirement).

240. See, e.g., 19 ANNALS OF CONG. 1330 (1809) (statement of Rep. Randolph) ("Among the duties-and among the rights, too- of this House, there is perhaps none so important as the control which it constitutionally possesses over the public purse."); Kate Stith, Congress' Power of the Purse, 97 YALE L.J. 1343, 1344 (1988) (delegation of power of purse to Congress "is at the foundation of our constitutional order").

241. See, e.g., S. REP. No. 104-5, at 26-27 (1995) (statement of Sen. Biden) (expressing concern that amendment will fundamentally shift balance of powers by permitting impoundment); H.R. REP. NO. 104-3, at 35 (1995) (dissenting views) (finding impoundment possible); Rodino, supra note 6, at 801 (stating that giving President impoundment power "would be inconsistent with our basic Constitutional structure").

242. S. REP. No. 104-5, at 9 (quoting Marbury v. Madison, 5 U.S. (1 Cranch) 137, 177 (1803)).

243. See id. at 10-11.

244. See id. at 10.

245. See id. at 9-10.

246. See id. at 11.

247. S.J. Res. 1, 104th Cong. $\& 6$ (1995), reprinted in Appendix.

248. See id. $\S 1$. 
might seem to authorize-indeed, require ${ }^{249}$ - the President to impound appropriated funds to the extent necessary to prevent a violation of the section's mandate. The 1995 Senate committee report, however, stated:

[I]t is not the intent of the committee to grant the President any impoundment authority under S.J. Res. 1. In fact, up to the end of the fiscal year, the President has nothing to impound because Congress in the amendment has the power to ratify or to specify the amount of deficit spending that may occur in that fiscal year. ${ }^{250}$

In effect, the report argued that section 1 was to be applied only to the year as a whole; as a result, compliance could not be determined until after the year was over. It would, therefore, alway's be 100 late for the President, or anyone else, to impose corrective action. While some may question this reading, ${ }^{\text {si }}$ the report clearly evidenced Congress's reluctance to allow the President any enforcement role beyond his existing veto power.

In sum, the 1995-96 Senate Draft reserved for Congress both the power to define what a balanced budget was and to take corrective action if Congress failed to comply voluntarily with its core requirements. Perhaps in response to anticipated likely criticism, the 1995 Senate committee report made two further arguments: (1) that the "primary enforcement mechanism" for the amendment as a whole was section 2 , which required a three-fifths vote to increase the debt ceiling; ${ }^{252}$ and (2) that the "ultimate enforcement mechanism" was the political process, through which voters would refuse to reelect members of Congress who did not comply. ${ }^{253}$ There is little evidence that the political process punishes politicians who vote to cut taxes or increase spending: ${ }^{254}$ it is, in part, this very failure that has led proponents to assert the need for a constitutional amendment. In effect, therefore, the requirement of a supermajority vote to raise the debt ceiling was the only proposed enforcement mechanism with any teeth at all. I will suggest below that this mechanism is wholly inadequate to the task. ${ }^{\text {ss }}$

249. See S. REP. NO. 104-5, at 15 (stating that... shall not exceed . . is a clear mandate a command").

250. Id. at 11 .

251. See, e.g., id. at 27 (statement of Sen. Biden); id. at $38-41$ (mınonty vews of Sens Kennedy. Leahy, and Feingold).

252. See id. at 8 .

253. See id. at 9.

254. See, e.g., 1995 Joint Hearings, supra note 2, at 82 (statement of Rep. Mlanzullo) (assenung that politicians are not necessarily punished for voling to cut taxes or increase spending): 1995 House Hearmgs. supra note 2, at 27 (statement of Rep. Schaefer) (same); ıd. at 140 (statement of Rep. Schroeder) (same). id. at 242 (statement of James D. Davidson. Chairman. Natıonal Taxpayers Unon) (same). 1994 Senate Judiciary Comm. Hearings, supra note 2, at 11 (statement of former Sen. Tsongas) (same). 1983-84 Senate Hearing, supra note 2, at 142-43 (statement of Sen. Hatch) (same): td. at 182 (statement of Langdon Flowers, representing National Association of Manufacturers) (same): id. at 312 (statement of Professor Milton Friedman) (same); 1979-80 House Hearings, supra note 2. at 4 (statement of Rep. MicClory) (same); id. at 65 (statement of James Davidson. Chairman. National Taxpayers U'non) (same); $t d$ at 362 (statement of Rep. Nelson) (same).

255. See infra Section III.B. 
Proponents of the 1995-96 Senate Draft may nevertheless point to the first sentence of section 6 which provides: "The Congress shall enforce and implement this article by appropriate legislation, which may rely on estimates of outlays and receipts."256 This sentence, it may be argued, would give Congress the power to experiment with enforcement procedures until it finds procedures that work. This argument, however, raises questions that some, particularly the states, may find disturbing: Does section 6 of the 1995-96 Senate Draft give Congress the power, by majority vote, to restructure the federal government in ways that would be unconstitutional absent that section? Stated another way, does section 6 amend Article $\mathrm{V}$ of the Constitution, which currently requires the affirmative vote of two-thirds of the members of each chamber and ratification by three-fourths of the several states to effect such a restructuring? ? $^{257}$ A negative answer to these questions may imply that the first sentence of section 6 is surplusage, a construction normally to be avoided. These questions are rendered acute by the second sentence of the same section, which precludes judicial review of "any case or controversy arising under this Article"258 except as permitted by statute.

An immediate practical consequence of section 6 and its approach to the problem is that the issue of enforcement is likely to remain open even if an amendment similar to the 1995-96 Senate Draft is ratified. By approving such a draft, Congress will simply defer solution of the problem, in the process possibly granting itself the power to restructure the federal government in ways that would otherwise be unconstitutional. In other words, the 1995-96 Senate Draft may actually expand congressional power, rather than constrain it.

Judicial enforcement, presidential impoundment, and a complete reservation of enforcement powers to Congress are not, of course, the only possible techniques for enforcing a budgetary target. Chairman Peter Rodino of the House Judiciary Committee wrote in 1983:

In the Ninety-seventh Congress alone, members of the House introduced more than sixty-five resolutions representing a wide variety of approaches. In various combinations, these proposals contain provisions with balanced budget "requirements," spending limitations, revenue limitations, borrowing limitations, and mandated schedules for the repayment of the national debt. Even within the general rubric of "balanced budget proposals," the resolutions would operate in widely varying manners. Some merely declare that the budget shall be balanced, while others restrict the power of Congress to appropriate. Various proposals require Congress to plan a balanced budget; place a general

256. S.J. Res. 1, 104th Cong. $\$ 6$ (1995), reprinted in Appendix.

257. See U.S. CONST. art. V ("The Congress, whenever two thirds of both Houses shall deem it necessary, shall propose Amendments to this Constitution ... [which] shall be valid to all Intents and Purposes, as Part of this Constitution, when ratified by the Legislatures of three fourths of the several States ....").

258. S.J. Res. 1, 104th Cong. § 6 (1995), reprinted in Appendix. 
duty on Congress to balance the budget; mandate that a deficit be extinguished within a given period; or merely establish a balanced budget as a goal. Finally, there are differences in such basic matters as whether the restrictions could be waived in times of war or other national emergency, and, if so, what emergency would suffice; how the restrictions would be enforced; and the anticipated role of the Executive in the budget process. ${ }^{259}$

Among the proposed enforcement mechanisms, the Chairman noted, were the line item veto and a provision giving the President the power to impose an income tax surcharge. $^{260}$ Since 1983 , the volume of proposals has, if anything, increased. ${ }^{201}$

This Article will not attempt a comprehensive review of outstanding proposais. Instead, it will attempt to reconceptualize the problem. First, I will suggest that enforcement problems fall into three categories: (1) how the target is defined each year and how compliance with the target is determined; (2) how a remedy is formulated and imposed if Congress fails to meet the target thus defined; and (3) how, if ever, the requirements of the amendment may be waived. It may be useful, I suggest, to examine each of these problems separately. Procedures for target definition, scorekeeping, and waiver may be amenable to current resolution. The most difficult problem is the second, that of imposing a remedy if Congress fails to comply voluntarily. I will suggest, in this regard, a new approach to categorizing and thinking about possible solutions. I am not yet able to offer a solution; my goal is rather to map the terrain and define the problems more sharply.

\section{A. Setting Annual Targets and Deciding Whether They Have Been Met}

Much has been written about whether courts should be empowered to cut spending, raise taxes, or order other remedies if Congress fails to balance the budget. ${ }^{262}$ Far less has been written about whether courts are best suited to interpret the budgetary target and determine whether it has been met. Perhaps this gap reflects greater comfort with cours in an interpretive and factinding role; it may also reflect an assumption that the two functions-keeping score and imposing a remedy - are part and parcel of a single task and should be assigned to a single body.

I would like to begin by considering the scorekeeping function separately and asking whether that aspect of the problem, at least, might be amenable to solution.

259. Rodino, supra note 6 , at 789-9I.

260. See id.

261. I am unaware of any catalog of balanced budget proposals introduced into Congress that purports to be complete, nor have I attempted to compile one. It is unlikely. however. that the current volume is less than one hundred per year.

262. See supra note 6. 
Who construes the portion of the amendment that defines the target? Who projects, for amendment purposes, the budgetary consequences of proposed congressional action? Who determines whether the target has been met? While these questions do raise separation of powers issues, they are not nearly as serious as those raised by proposals to authorize presidential impoundment or to permit courts to take remedial action.

The 1995-96 Senate Draft reserved these tasks to Congress itself. As Part II of this Article has demonstrated, effective enforcement of a balanced budget amendment requires outside review of congressional action. Outside review would permit the development of rules to respond to attempts to circumvent the amendment through innovative accounting rules or by moving deficits off-budget. It would also allow contemporaneous review of congressional action, without waiting for receipts to be received and expenditures to be made. Permitting Congress to control target definition and scorekeeping, by contrast, would be like imposing an income tax but permitting taxpayers to define "income" and audit their own returns.

Should the scorekeeping function be assigned to the executive branch? Like the 1995-96 Senate Draft, the Gramm-Rudman-Hollings Act attempted to reserve scorekeeping to the legislative branch, specifically to the Comptroller General. Under that Act, a determination by the Comptroller General that the budgetary targets had not been met was sufficient to trigger sequestration. In Bowsher v. Synar ${ }^{263}$ the Supreme Court held this structure unconstitutional on the ground that the role assigned to the Comptroller General was inherently executive. ${ }^{264}$

Whatever the merits of Bowsher, we are not bound by it in drafting a new constitutional amendment. There are at least two disadvantages to assigning the scorekeeping function to the executive branch. First, as a practical matter, doing so would probably strengthen the executive branch at the expense of the legislative. At the very least, we might expect that Congress, which controls amendment drafting, would be reluctant to adopt such a solution. Moreover, there is no obvious reason to believe that the executive branch would do a better job. Like Congress, the Executive is a political branch, prone to the same pressures to spend and not tax. Although it may be easier for the electorate to hold the President personally accountable, the scorekeeping function is sufficiently technical that it is unlikely that a President would be politically vulnerable for, say, a decision to use the cash method.

Under traditional three-branch analysis, this leaves only the courts. As I have noted, most discussion of the proper role of the courts in enforcing a balanced budget amendment has focused on the problem of remedies. It has been suggested that courts do not have the expertise to assess budgetary issues. ${ }^{265}$ Proponents

265. See, e.g., Rodino, supra note 6 , at 801 . 
of judicial review have noted, in turn, that courts deal with complex economic and other technical issues all the time. ${ }^{266}$

Both proponents and opponents, I suggest, are asking the wrong question. The question is not whether courts could appropriately interpret the rules defining the budgetary target and make factual findings as to whether the target has been met. Of course they could. The proper question is whether the amendment would function most effectively if scorekeeping were assigned to the courts. The answer, I suggest, is no.

First, as Part II demonstrates, the problem of budgetary target definition is technically complex. Not only is the potential for circumvention high, but effective circumvention may be relatively easy to conceal. The ideal scorekeeper therefore needs independent economic, accounting, and financial expertise. It should be able to apprehend the most sophisticated circumventions and respond promptly to developments in economics, accounting, and finance. The adversarial model, in which advocates supply competing sources of expertise and a neutral, but not necessarily expert, body determines which argument is more "credible," is less likely to result in the prompt, effective identification of problems.

Second, although some degree of rule stability is important, the ideal scorekeeper should not be bound by stare decisis. In tax. an interpretation of the Internal Revenue Code that creates a loophole can be remedied by legislation. If the scorekeeper for a balanced budget amendment were bound by stare decisis, however, the consequences would be far more severe. An interpretation that creates a loophole or implements an economic theory later subject to challenge would be correctable only by constitutional amendment.

Third, the ideal scorekeeper should be able to respond quickly and to render advisory decisions as needed. Congress should not have to guess whether proposed tax or spending legislation will result in a violation of the amendment. In other contexts, it may be appropriate to require Congress to determine as an initial matter whether a statute is constitutional and defer final resolution of the issue until a case or controversy arises. Tax and spending legislation, however, is necessary to the ongoing, day-to-day administration of the federal government. The amendment would function more efficiently if Congress could obtain an authoritative advance determination whether a particular program or change in law would comply. In addition, an expedited advance ruling procedure would leave more effective power in Congress's hands and be less disruptive of legislative and political processes.

Finally, the ideal scorekeeper should have rulemaking power. It should be able to define general interpretive principles so as to allow Congress to make policy with some assurance that its decisions will not be second-guessed, even in the absence of an advance ruling. It should be able to consider interpretive issues

266. See, e.g., Bowen, supra note 6, at 589-93. 
systematically, not merely as they are presented by specific cases and controversies.

It follows that the courts are probably not the ideal scorekeepers. They are not expert; they are bound by stare decisis; the federal courts, at least, are prohibited from issuing advisory decisions; and they lack substantive rulemaking power. These deficiencies could, of course, be remedied in the amendment itself. The resulting institution, however, would not look very much like an American court.

To ask the courts to serve as scorekeepers would also threaten the integrity of the courts themselves. Confirmation hearings would likely come to focus significantly on economic, accounting, and financial issues. The best legal minds would not necessarily make the best fiscal arbiters, nor would the best economists make the best jurists. Politicization of the courts, which some argue is already a problem, ${ }^{267}$ would likely become far more serious.

A nontraditional model merits consideration-a body constitutionally independent of the three existing branches, charged solely with the tasks of interpreting the rules, defining the budgetary target, and determining whether budgetary targets have been met, but not with the task of formulating a remedy if they have not. Administration of the scorekeeping function by such an independent body would have significant advantages. It could be given the requisite independent expertise and capacity to analyze data, would not need to be bound by stare decisis, could render prompt advisory decisions, and could make rules. In addition, creation of such a body would permit the amendment to define its target by reference to values, rather than numerical tests. ${ }^{268}$ The independent scorekeeper would then set periodic numeric targets, annually or over whatever period or periods would most effectively accomplish the purposes of the amendment. This, in turn, would permit the scorekeeper to accommodate the fiscal policy concerns discussed in Section II.D above: The scorekeeper could define economically prudent transitional targets in a manner that would retain the federal budget's stabilizing features, as well as respond prudently to economic

267. Professor Friedman has discussed this problem outside the balanced budget context: "Extended debates, both within the Senate and beyond, concerning recent decisions and the political philosophy of a nominee cannot help but diminish the Court's reputation as an independent institution and impress upon the public-and indeed on the Court itself-a political perception of its role." Richard D. Friedman, Tribal Myths: Ideology and the Confirmation of Supreme Court Nominations, 95 Y ALE L.J. 1283, 1317 (1986). An extended debate regarding a judicial nominee's views of Social Security or tax rates would only compound the problem. The scholarly literature on the proper role of politics in the confirmation of judicial nominees is extensive. See, e.g., STEPHEN L. CARTER, THE CONFIRMATION MESS (1994) (arguing that confirmation process has gone awry); David A. Strauss \& Cass R. Sunstein, The Senate, the Constitution, and the Confirmation Process, 101 YALE L.J. 1491 (1992) (advocating more independent Senate role to reduce partisanship); John O. McGinnis, The President, the Senate, the Constitution, and the Confirmation Process: A Reply to Professors Strauss and Sunstein, 71 TEX. L. REV. 633 (1993) (advocating more limited Senate role); Essays on the Supreme Court Appointment Process, 101 HARV. L. REv. 1146 (1988) (collection of five essays on Supreme Court appointment process).

268. Section I of such an amendment, for example, might read simply as follows: "The fiscal policy of the United States Government, as reflected in its net budgetary surplus or deficit, shall be responsible, economically prudent, and fair to future generations." 
emergencies. Finally, creation of such a body would avoid any shift in the balance of powers among the three existing branches.

I do not claim that such a solution is without problems. Creation of an independent scorekeeper would necessarily infringe on the current scorekeeping prerogatives of the political branches. Even seemingly technical rulings by such a body would generally have substantial political implications, to which it seems unlikely that the scorekeeper would be oblivious. On the other hand, any amendment that provides for outside review of congressional compliance will necessarily infringe on the current scorekeeping prerogatives of Congress. Under an independent scorekeeper, at least some degree of depoliticization would likely occur. At worst, the political branches would regularly be forced to persuade an only partially politicized scorekeeper that they had not strayed too far from the spirit of the amendment.

I also do not claim that creation of an independent exper body would solve the entire enforcement problem. What to do if Congress fails voluntarily to adhere to declared targets and when to permit waiver of those targets for competing policy reasons are issues that would still need to be addressed. Such a body could, however, credibly solve the information problem. A single set of analyses perceived to be expert, authoritative, and relatively nonpartisan and nonmanipulative would substantially advance resolution of the problem as a whole.

\section{B. Imposing a Remedy}

A much more difficult problem is that of forcing democratically elected legislators to do what they, and perhaps the sovereign People, ${ }^{3(\theta)}$ do not want to do. However the target is defined, what remedy should be imposed if the political branches fail to meet that target voluntarily? We do not yet have a consensus on an answer. The 1995 Senate committee report characterized the approach taken in the 1995-96 Senate Draft as an "auxiliary precaution."7io This characterization, however, begs the most important question: How will it work in practice? I suggest that it may be useful to focus on the basket of taxes that will actually be collected and expenditures that will actually be made if the target is not met voluntarily. I will call this basket, which presumably would be structured to comply with the target, the amendment's "default solution." So framed, the question of remedy has two parts: What is the amendment's default solution? And through what processes is it defined?

I propose that a good default solution should meet at least two criteria. First, it should not be broadly unacceptable. This is, admittedly, a fuzzy measure. Our

269. The fact that the sovereign Pcople. through their representauses, adopt a constitutional amendment today does not necessarily mean that a majonty of the People ten or a hundred years hence will agree that the federal budget should be balanced.

270. S. REP. NO. 104-5, at 2-3 (1995). 
democracy normally validates political outcomes by majority vote. The default solution cannot be defined through normal democratic processes because, by hypothesis, those processes have failed. Nevertheless, I submit that some default solutions are broadly unacceptable and should therefore not be incorporated into any proposed amendment. A default solution involving substantial risk of a collapse of the U.S. economy, for example, would fall into this category. Second, the default solution should reflect, to the extent possible, the contemporary democratic will. ${ }^{271}$ Although, by hypothesis, normal democratic processes have failed, a default solution that reflects, to the greatest extent possible, the contemporary democratic will is superior to one that does not. This is one of the reasons that courts should probably not define the default solution; the federal courts, at least, are intentionally countermajoritarian.

Not all readers will agree with these criteria. Even those who subscribe to different criteria, however, may find the proposed analytic approach useful. The remainder of this Section will consider some of the more commonly suggested balanced budget remedies through the lens of this approach.

\section{Debt Ceiling Limitations}

The debt ceiling limitation of section 2 of the 1995-96 Senate Draft has been billed as the "primary enforcement mechanism" for that draft. ${ }^{272}$ What does the proposed analytic approach tell us about how such a mechanism might work? Under a debt ceiling limitation, the government taxes and spends as authorized by Congress, borrowing to cover any shortfall, until the moment it reaches the debt ceiling. Amounts spent prior to that moment are unaffected by the amendment. Subsequent spending is permitted only to the extent of subsequent receipts. In effect, the default solution for the fiscal year as a whole consists of: (1) existing revenues; (2) expenses actually paid prior to the debt ceiling crisis; and (3) some portion of the remaining spending authorized by Congress but not undertaken until after the debt ceiling is reached. Expenses paid earlier, therefore, enjoy effective priority over those to be paid later.

There are several problems with such a "first-in-time" solution. First, it is arbitrary. Amounts spent earlier will not necessarily be higher in policy priority than those authorized to be spent later. Unless the process is manipulated, a problem that will be discussed shortly, the choice of which spending to cut is essentially random. Although elected leaders disagree about many things, they do tend to agree, for example, that interest on the national debt should be paid before funding is given to the National Endowment for the Arts. A process more

271. I recognize that a mathematically satisfactory definition of "contemporary democratic will" may be problematic. See, e.g., James M. BUCHANAN \& GORDON TUllock, THE Calculus of Consent: LOGICAL FOUNDATIONS OF CONSTITUTIONAL DEMOCRACY 326-34 (1974) (exploring theoretical problems of majority rule). I apply here its intuitive meaning, which is inexact but useful.

272. See supra text accompanying note 252 . 
consistent with democratic theory would reflect legislative priorities to the greatest extent possible. At the very least, it would attempt to exempt any spending deemed essential.

Because of its random nature, actual implementation of a first-in-time solution may be broadly unacceptable. It may, for example, require the government to default on the national debt. In such an event, the amendment, in effect, takes hostage some public interest perceived to be of overriding importance. "Balance the budget," the amendment threatens, "or I will destroy the U.S. economy." 273 This creates two undesirable possible dynamics. A legislative minority ${ }^{274}$ may be tempted to join in the hostage-taking, demanding passage of measures not directly related to or, perhaps, contrary to the goal of budgetary balance as a condition of permitting the supermajority vote necessary to waive the limitation-measures that would not otherwise survive the legislative process. In 1996, for example, some members of the House threatened to prevent passage of a debt ceiling increase unless the President agreed to Republican budget priorities for the next seven years, including a major tax cut. ${ }^{275}$

The majority, of course, may not believe that the minority is serious. This creates a second possible dynamic. To use hostage-taking effectively, the minority may attempt to persuade the majority that it is more willing to risk the unacceptable consequence than the majority, a tactic known to teenagers and

273. See S. REP. No. 104-5, at 16 (noting that under amendment. "whenerer the Govemment exeeds the debt ceiling, it runs a theoretical risk of default, a powerful incentuve for balaneing the budget") There is some uncertainty about the consequences of a default on the nationa! debt. Comparte Mlichael Canoll. Containing Default, INSTITUTIONAL INVESTOR, Apr. 1. 1996. at 50 (describing potential collapse of credit. repo, municipal bond, and currency markets), and Jonathan Peterson. The Defutult Debase. Treasun. Fed Differed on How to Plan for the "Unthinkable". L.A. TIMES. Apr. 7. 1996. at DI (describing "melidown of the financial system"), and Martin Walker, U.S. Treasun Threatened whh Defuul, GL tRDiAs (London). Sept. 26, 1995, at 17 (asserting that default "would make the 1929 Wall Street crash look like a tea party"). with James J. Angel, Looking Back at Debt Defauls in U.S. Histon. CHI. TRIB. Feb I. 1996. at 21 (concluding that U.S. default "would not be the end of the world"). With respect to this uncertannty. Louss Crandall, chief economist at R.H. Wrightson, has stated: "To say that the global financtal system will probably not collapse is a bit like saying that the odds of surviving Russian roulette are really quite high The statement is true but irtelevant. The only point that matters is that playing with loaded guns is a bad idea." Kevin Muehring, The Trader at Treasury, INSTITTTIONAL. INVESTOR. Jan. 1. 1996. al 41

274. For these purposes. I use the term "minonty" to include any group that lacks the power to enact legislation on its own.

275. See, e.g., Heidi Glenn, White House, Budget Commutrees Clash Oser Debt Caling Increase. Tix NOTES TODAY, Sept. 20, 1995, available in LEXIS. Taxana Librany. TNT File. 95 T.TT ist-6 inoung that Reps. John Shadegg and Christopher Shays "warned that untll President approveldl Cungress's seicn-yedr balanced budget plan, they would vote aganst any debt celling increase"). Fred Stoheld. C(Ot' Threatens to Oppose Federal Debt Ceiling Increase. TAX NOTES TODAr. July 31. 1995. as alable in LEXIS. Taxana Library, TNT File, 95 TNT 148-3 (noting that Rep. Nich Sinth and about 160 of his Houxe colleagues pledged to vote against debt-ceiling increase until reconciliation bill became law). Members also attempted to condition passage of the debt ceiling increase on abolition of the Commerce Depanment. see Jonathan Peterson, Default Scenario Looms Larger as Budget War Rages, L. A. TINES. Nor 9, 1995, at A26, ant1abortion provisions, see Eric Pianin, GOP Moves on Budgel, Siruggles with Debt Limur. Wasi Post. Nov 4,1995 , at A6, an amendment restricting political adiocacy by nonprofit groups that receve iederal grants. see id., and a provision to narrow the use of habeas corpus. see Maggle Micieil. Debl Lumi Increase. Has Require Conditions, Dole Said, RELTERS N. AM. WIRE. Nov. 5. 1995. avaluble in LEXIS. Neus Lubrany. REUNA File. 
military theorists as the game of "chicken."276 In effect, each side threatens to let hostages die unless the other concedes; in the process, each may find it tactically beneficial to persuade the other that it is more committed (and perhaps less rational) than the other. Neither hostage-taking nor games of chicken belong in our system of government.

A third possible problem is that any first-in-time solution, without more, in effect grants impoundment power to the President. Knowing that a debt ceiling crisis is imminent, the President may accelerate outlays he favors and delay outlays he opposes. ${ }^{277}$ Once the debt ceiling is reached, in the absence of a contrary statutory directive (which, of course, he may veto), the President will then be asked to choose which outlays will be made out of the government's continuing receipts and which will not. ${ }^{278}$

The committee report to the 1995-96 Senate Draft disavowed any intention to grant such impoundment power. For this reason, the report suggested that section 1 of the Draft, which prohibited outlays in excess of receipts, be enforceable only as provided by Congress. ${ }^{279}$ The debt ceiling supermajority rule of section 2, by contrast, was to be self-executing. ${ }^{280}$ I suggest that this attempted distinction is futile. To the extent that they are self-executing, both sections effectively authorize impoundment. The principal difference is that section 1 requires presidential action as soon as outlays exceed receipts. ${ }^{281}$ By contrast, section 2 permits outlays in excess of receipts until the debt limit is

276. See, e.g., Herman KAHN, Thinking ABOUT THE UNTHINKABle 44-50, 187-208 (1962) (discussing game of "chicken" as useful analogy for modern political strategy); Carroll, supra note 273. at 50 (discussing 1996 debt ceiling crisis); Alan Fram, Gingrich Eases Stand on Tax-Cut Package, NEw ORLEANS Times-PICAYUNE, Feb. 2, 1996, at A3 (same); Get on with It, ProvidenCE J.-Bull., Jan. 16, 1996, at B4 (same); Joanne Morrison, Deputy Treasury Secretary Says Congress Must Increase Debt Limit to Avoid Default, BOND BUYER, Feb. 22, 1996, at 32 (discussing 1996 debt ceiling crisis); Muehring, supra note 273, at 41 (discussing 1995 debt ceiling crisis); Playing Chicken with Government, PATRIOT LEDGER, Jan. 31, 1996, at 10 (same); William Safire, 'Notorious Defaulter', N.Y. TIMES, Jan. 25, 1996, at A21 ("You don't play a game of chicken with the U.S. dollar."); David E. Sanger, Feds Seeking to Avert a Default, DENV. POST, Nov. 13, 1995, at Al (discussing nuclear war analogy); Marina V.N. Whitman, Political Silly Season Promises Little Relief, DET. NEwS, June 2, 1996, at B7 (calling 1995 government shutdowns games of chicken).

277. The Anti-Deficiency Act requires that appropriations be apportioned "to prevent obligation or expenditure at a rate that would indicate a necessity for a deficiency or supplemental appropriation for the period." 31 U.S.C. $\S 1512$ (a) (1994). In the face of an impending budgetary shortfall, however, it docs not appear that the Act would create any serious impediment to the substantial exercise of presidential discretion as to how that shortfall should be allocated across the budget.

278. In so choosing, the President also has the power to determine which programs the amendment takes hostage. For example, he may state that if Congress fails to pass requested legislation, he will (or, more probably, "will be forced to") withhold payment of Social Security benefits. Strategic use of such threats may give him substantial leverage, particularly if his party controls a blocking minority vote in either house of Congress: A supermajority debt ceiling provision allows a minority in either house to prevent passage of a debt ceiling increase. Again, such requested legislation may bear no relation to the deficit. Since the President is democratically elected and subject to the same political forces that have led to Congress's own failure to balance the budget, a transfer of power to the President will not necessarily further purposes of the amendment.

279. See supra text accompanying notes $250-51$.

280. See S. REP. No. 104-5, at 8, 16 (1995).

281. See S.J. Res. 1, 104th Cong. § 1 (1995), reprinted in Appendix. 
reached. It thereafter authorizes exactly the same kind of unilateral presidential action. $^{282}$ By relying on section 2 rather than section 1, the 1995-96 Senate Draft merely deferred what it promised to avoid. ${ }^{233}$

Indeed, a self-enforcing section 1 would arguably be superior to section 2 in at least two regards. First, it would catch the deficit problem earlier in the fiscal year, permitting less spending arbitrarily to escape remedial cuts. To the extent that presidential priorities reflect the contemporary democratic will, the resulting solution would be preferable. Second, it is easier to argue that a modified, rather than pure, cash method may be used in construing section I; if so, section 1 may be made less vulnerable to some of the circumvention techniques outlined in Part II above. As noted there, use of the debt ceiling as an enforcement tool requires the use of pure cash method accounting in defining the target, with all of the avoidance potential of that method. In sum, reliance on a debt ceiling limitation as the "principal enforcement mechanism" of a balanced budget amendment seems profoundly unsatisfactory. ${ }^{284}$

\section{Predefined Default Solutions}

A second type of default solution explicitly predefines the adjustments to be made. The Gramm-Rudman-Hollings Act, ${ }^{285}$ for example, exempled certain entitlement spending, interest on the national debt, and other limited items but otherwise generally required across-the-board spending cuts within major categories to the extent necessary to meet the target. ${ }^{286}$ A predefined default solution may be specified either by statute or in the amendment itself. The

282. See id. $\S 2$.

283. Senator Kennedy proposed to add language to the draft to the effect that. "“[n]othing in thus article shall authorize the President to impound funds appropnated by Congress by law ' S R:s No 104 . 5, at 27 (presenting additional views of Senator Biden in which he quotes Senator Kennedy) His proposal was defeated. See id. at 13. Even had it been adopted, however. the President mould have had eflectuve impoundment power under section 2. The Impoundment Control Act of 1974 requires that the President submit a special message to Congress reporting any proposed rescisston of budget authonty. ser 2 L' S C $\$ 683(a)$ (1994), and prohibits such rescission unless Congress completes action on a rescission bill uthın 45 days, see id. $\$ 683($ b). The Comptroller General is authonzed to bning a cwil action in the l's Distrut Court for the District of Columbia to require that any umproperly rescinded authority be made asalable See 2 U.S.C.A. $\$ 687$ (West Supp. 1995). It seems unlihely, howeser, that the Act would be construed to require the President to spend money that he does not have.

284. See, e.g., Prepared Statement by Mickey D. Le'v. Chref Economist. NanonsBanc Captual Markets Inc., Before the House Commintee on Banking and Fintanctal Sentces Perspectures on the Federal Debt Ceiling and Budget Policy, FED. News SERV., Feb. 8. 1996 ("The federal debt ceiling is not an effectue economic mechanism for achieving fiscal responsibılity."). The hostage+tahing potential of debt ceslung limitations has even led some to urge that the debt celling be elıminated enturely See. 8 . Gingrich's Game of Chicken Dangerous Sham, Useful Only for the W'orst Polutucal Purposes. I's Time to Dump It. FRESNO BEE, Oct. 22, 1995, at B6 (noting that Gingnch's own budget office calls debt ceiling "an anachronism"); Peterson, supra note 273, at DI (noting that "growing number of economists" urge eliminating debt ceiling altogether).

285. Balanced Budget and Emergency Deficit Control Act of 1985. Pub. L. No 99.177. 99 Stat 1038 (codified as amended at 2 U.S.C. $\$ \S 900-22$ (1994)).

286. See H.R. CONF. REP. NO. 99-433, at 78-95 (1985), reprinted in 1985 U.S C C A.N 996-1013 (describing sequestration rules and procedures). 
principal advantage of such a solution is that it is less arbitrary than a first-in-time outcome and therefore is less likely to be broadly unacceptable. This approach, however, has at least three problems.

First, a predefined solution will not necessarily reflect the contemporary democratic will; it will instead reflect the priorities and views of the legislature in power at the time the solution was defined. The will of the people, as reflected in their elected legislators at the time of the definition, may have changed by the time the solution is invoked. Alternatively, circumstances may have changed. There may, for example, be a higher need for military preparedness spending than when the predefined solution was adopted. A predefined solution, therefore, is likely to be less responsive, intelligent, or consistent with democratic theory than a solution involving legislators currently in office. ${ }^{287}$

This problem is exacerbated if the predefined solution is hard to change; it is most serious if the solution is set forth in the amendment itself. For example, the balanced budget amendment proposed and passed by the House in 1995 included provisions that would have required a supermajority vote in each chamber to enact any "revenue increase." ${ }^{288}$ While such a statement of priorities may reflect the views of a majority today, based on today's needs, it will not necessarily reflect the views of the same majority in changed circumstances. It might be argued that Congress, understanding the operation of a balanced budget amendment, would also understand the default solution such an amendment would impose in the event of a deficit. Thus, in approving Budget A, violative of the amendment, Congress might be aware that in fact it was approving Budget $B$, the default solution imposed by the amendment in such circumstances. If so, a predefined solution might well reflect the contemporary democratic will. There are at least two problems with this argument. First, it assumes that a Budget B reflecting the contemporary democratic will is always available under the amendment. This may not be the case. For example, the contemporary democratic will may favor tax increases rather than spending cuts; the amendment's predefined solution may not permit tax increases. Second, it assumes that members of Congress are well-informed about matters that come before them. While this may be true in general, it is less likely to be true when the budget "actually" under consideration is not the budget described in the law and reports before them. Any predefined default solution should be amendable through standard majoritarian processes.

A second problem is not so easily solved. Any balanced budget amendment is based in part on the premise that enacting a balanced budget is politically

287. Assume, for example, a world in which Congress realistically has only three options: cutting military preparedness spending, cutting Social Security, or raising taxes. Assume further that Social Security remains sacrosanct. Many who would vote today to limit the federal government's power to tax might well prefer tax increases to military cuts in this hypothetical but not entirely unrealistic world. To adopt a predefined solution for all time requires either extraordinary prescience or extraordinary hubris.

288. See H.R. REP. No. 104-3, at 1 (1995). 
difficult. But if Congress cannot make difficult decisions when confronted with an actual deficit crisis, it may be unreasonably optimistic to expect Congress to make the same difficult decisions in advance. Indeed, difficult decisions about actual taxes and spending may produce actual budgetary balance, with a corresponding possibility of political reward. Difficult decisions about predefined solutions, by contrast, offer little in the way of offsetting reward.

A third, more technical, problem vastly complicates the predefinition of any truly satisfactory default solution: The form in which spending is authorized does not necessarily reflect Congress's priorities. Government spending takes many different forms, some far more resistant to adjustment than others:

(i) Spending subject to annual appropriation is most vulnerable; in the absence of congressional and presidential action, it simply stops. This category includes most military spending, which cannot constitutionally be appropriated for periods exceeding two years. ${ }^{289}$ Until recently, most efforts to balance the budget focused on possible cuts in annual appropriations, which currently average in excess of $\$ 500$ billion per year. ${ }^{290}$

(ii) Spending subject to permanent appropriation is less vulnerable; in the absence of congressional and presidential action, it continues. Since this category averages roughly $\$ 1000$ billion per year, ${ }^{391}$ its exclusion from budget-cutting efforts has significantly compounded the difficulty of those efforts. Nevertheless, even such "nondiscretionary" spending requires cash outlays and may therefore be subject to limitations on outlays or debt.

(iii) Both annual and permanent appropriations include some funds authorized to meet existing contractual obligations. These appropriations are substantially less vulnerable to budget-cutting measures since, as a practical matter, the government cannot abrogate its contractual obligations. So long as the obligation itself survives, a reduction of such outlays in one year merely results in a corresponding increase in later years, generally with interest. The government may terminate contracts, but such terminations often trigger major buyout costs. ${ }^{2} 2$

(iv) Under both current budgetary procedures and the 1995-96 Senate Draft, spending by revolving funds to the extent of collections by those funds is immune from cuts, since collections are treated as of fsets to outlays, not as receipts. A revolving fund whose spending does not exceed its collections will report no outlays whatsoever; as a result, there is nothing

289. See U.S. CONST. art. I, \& 8, cl. 12.

290. See Department OF THE TREASt'RY, supra note 20, al 201-08.

291. See id. at 211-12.

292. Indeed, the agency negotiating the contract may acturely sceh high contratiusl buyout costs to protect the agency's appropriations. 
to cut. Expenditures in this category currently average roughly $\$ 200$ billion per year. ${ }^{293}$

(v) Tax expenditures are similarly excluded from outlays. Public finance theory recognizes that the same subsidy may be given either as a cash grant or as a targeted tax preference, of which the Internal Revenue Code contains many. Tax expenditures, measured as "outlay equivalents," currently average in excess of $\$ 500$ billion per year. ${ }^{294}$ Because such expenditures are not treated as "outlays," but merely as reduced receipts, they are immune from attempts to control "outlays." Indeed, under proposals requiring a supermajority vote to "raise taxes," there is a substantial risk that tax expenditures could not be adjusted without such a vote. ${ }^{295}$

(vi) Finally, expenditures by off-budget, government-sponsored entities are excluded from the budget entirely and are therefore immune from budget-cutting efforts. ${ }^{296}$ Currently, gross outlays by such entities average roughly $\$ 500$ billion per year. ${ }^{297}$

I do not suggest that all such expenditures should be cut as part of any default solution. That certain programs are permanently appropriated does sometimes indicate higher standing. On the other hand, many considerations may lead Congress to elect to make annual, rather than permanent, appropriations. As has been noted, for example, military appropriations are constitutionally limited to two years; ${ }^{298}$ this does not necessarily indicate a preference that military spending be cut first. Similarly, a decision to enter into contractual obligations may result from pragmatic or business considerations, not from Congress's desire to protect the program from possible budget cuts. The decision to structure a program as a revolving fund presumably reflects an attempt to create a more-orless independent operation. Given a choice between avoiding default on the national debt and building a new TVA dam, it seems unlikely that Congress would choose to permit the default and build the dam-although section 2 of the 1995-96 Senate Draft apparently allows this to occur. ${ }^{299}$ Similarly, that a subsidy is delivered in the form of a tax expenditure may reflect nothing more

293. See Department OF THE TREASURY, supra note 20, at 383-500 (aggregating "[s]pending authority from offsetting collections" for all revolving funds).

294. See id. at 70-72.

295. See, e.g., SATURNo, supra note 2, at 37-40 (arguing that "a limitation on increases in receipts would limit Congress's ability to eliminate tax expenditures to achieve a balanced budget because eliminating tax expenditures would increase receipts rather than reduce outlays, and thus increase the risk of running afoul of such a limitation").

296. See supra note 206 and accompanying text.

297. See Department of THE TREASURY, BUdGet of THE UNITEd STATES GOVERNMENT, Fiscal YEAR 1997, app. 1129-45 (1996) (aggregating budget line 87.00, "outlays (gross)," for all reported offbudget entities).

298. See supra text accompanying note 289.

299. See S.J. Res. 1, 104th Cong. $\$ 2$ (1995), reprinted in Appendix. 
than that its sponsor was a member of the House Ways and Means or Senate Finance Committee rather than the relevant appropriations subcommittee. Ideally. a default solution would be neutral as among these forms of spending and would instead reflect conscious congressional choices based on the merits of each program.

A nonneutral default solution may also distort congressional decisionmaking. Consider, for example, an amendment that requires deficits to be met by spending cuts, not tax increases. Such an amendment creates an incentive to structure favored spending programs as tax expenditures. In the long run, such an amendment might result in a badly distoned tax system. ${ }^{300}$

In sum, predefined default solutions are likely to be better than first-in-time solutions. Any predefined solution, however, overrides to some extent the contemporary democratic will. In addition, for both political and technical reasons, Congress seems unlikely to adopt a comprehensive and fully considered predefined default solution.

\section{Process-Based Solutions}

A third possibility is to invoke extraordinary decisionmaking processes whenever the standard legislative process fails to meet the target; these extraordinary processes may then be used to structure the default solution. The principal advantage of a process-defined solution is that it can be drafted when needed and may therefore better accommodate contemporary needs and the contemporary democratic will.

The traditional approach to constitutional enforcement, the cour-ordered remedy, is perhaps the most obvious example of a process-defined solution. When normal legislative processes fail, we may ask the courts, or a specially designated court, to restructure federal appropriations, tax, and other related laws to comply with the target. Courts have exercised quasilegislative powers in cases involving schools, prisons, and municipalities. ${ }^{301}$ As both Congress and commentators have recognized, however, courts are not institutionally well-suited to decide whether spending is to be cut, which spending programs to cut, or whom to tax,

300. This may be an acceptable result. In choosing a predefined solution that far on tax expenditures. however, Congress should be aware that it places significant stresses on the tax system and may mahe tt politically far more difficult to effect thoroughgoing tax reform.

301. See, e.g., Lloyd C. Anderson, Implementanon of Consen Decrees in Structural Reform Litigation. 1986 U. ILL. L. REV. 725 (analyzing role of courts in implementation of consent decrees). Richard $H$ Fallon, Jr., Of Justiciabiling: Remedies, and Public Law Lutigation: Notes on the Jurnsprudence of Lyons. 59 N.Y.U. L. REV. 1 (1984) (criticizing Supreme Coun's effors to lımit publıc lau lilıgation), Donald L. Horowitz, Decreeing Organizational Change: Judictal Supentsion of Public Instruthons. 1983 DL XE LJ 1265 (examining problems of institutional litigation): Susan P Sturm. The Legacs and Future of Corrections Litigation, 142 U. PA. L. REV. 639 (1993) (discussing coun involvement in prison litigation). Carl Tobias, Public Law Litigation and the Federal Rules of Cwil Procedure. 74 CORNELL L REv 270 (1989) (describing procedural issues raised by institutional and other publıc law litigation) 
if taxes are to be raised. ${ }^{302}$ A court-ordered solution also effectively disenfranchises the electorate. It is true that any amendment-imposed decision to cut spending or increase taxes is necessarily countermajoritarian; we would prefer, however, that which spending to cut and which taxes to raise reflect, to the extent possible, the contemporary democratic will. Finally, were courts required to make such decisions, they would inevitably be politicized and could thereby lose credibility in their more traditional roles. ${ }^{303}$ These problems are serious enough to preclude the court-ordered remedy as a possible default solution. The same problems militate against giving any other nonpolitical body the power to formulate a default solution. To perform its target definition and scorekeeping tasks most effectively, an independent scorekeeper must be insulated to some degree from political forces. This restriction, however, makes it incapable of devising a default solution that reflects the contemporary democratic will. Similarly, asking the scorekeeper to devise solutions would inevitably politicize that body, undermining its credibility in target definition and scorekeeping.

This leaves the two political branches. If Congress fails to balance the budget, some may be tempted to give the President the power to do so. We have already examined one process-defined solution that transfers legislative power to the President: the debt ceiling limitation approach implemented in section 2 of the 1995-96 Senate Draft, which effectively grants impoundment power to the President. ${ }^{304}$

There are at least two problems with giving the President the power to define the default solution. The first is both technical and political. As has been noted, spending takes many different forms. To give the President the power to make considered choices among all such forms would require giving him the power, in effect, to rule by decree on matters affecting taxation, spending, borrowing, and control of the currency. We may limit that power-impoundment, for example, is a limited form of rule by decree-but in doing so we are likely to reduce the rationality of the resulting default solution, since we will necessarily be limiting the President's power to make reasoned choices among alternatives. Although the President is democratically elected, giving him the power to rule by decree (whether limited or not) will trouble many. Separation of powers was originally conceived as one of the Constitution's principal protections against tyranny. ${ }^{305}$

302. See supra notes $234-38$ and accompanying text.

303. The problem of politicization is greater, I suggest, in the case of federal spending and tax decisions than, for example, in the case of school, prison, or municipal administration. Spending and tax decisions are far more visible and generally far more contentious at the national level.

304. See supra notes $277-83$ and accompanying text.

305. See THE FEDERALIST No. 51, at 335 (Alexander Hamilton or James Madison) (Edward Mead Earle ed., 1937) (arguing for importance of "partition of power among several departments"): see also S. REP. No. 104-5, at 27 (1995) (additional views of Sen. Biden) ("The founders also intended the power of the purse to be one of the legislative branch's strongest bulwarks against incursions by the executive, and the key to maintaining an enduring balance of powers."). 
The second problem is theoretical. Most arguments in favor of an amendment to force a balanced budget imply, to some degree, that the political branches are incapable of doing the job on their own. At least some arguments commonly made about Congress's failings in this regard apply logically to the presidency as well. $^{306}$ Presidents who raise taxes or threaten Social Security feel the electorate's wrath no less than members of Congress who do the same. It is possible, therefore, that an amendment giving the President the power to rule by decree in the event of a deficit would merely transfer power to the President without any guarantee that he would use that power for the intended purpose.

\section{Incentive-Based Solutions}

Each of the foregoing approaches has been considered, in one form or another, by Congress. A fourth possible approach. by contrast, has received virtually no public consideration; nor do any persuasive exemplars exist. I nevertheless raise the possibility of focusing on "incentive-based solutions" because they are suggested by public choice theory, have intuitive appeal, ${ }^{\mathrm{k} 7}$ and would avoid many of the problems discussed in connection with other approaches.

Public choice theory suggests that Congress's failure to balance the budget under current rules results from the inadequacy of existing legislative incentive structures. ${ }^{308}$ Advocates have generally used this premise to justify first-in-time or process-based solutions; ${ }^{309}$ they have not generally explored the possibility of changing legislative incentives directly. As I define it, an incentive-based solution would do just that: It would induce Congress to comply with the budgetary target on its own.

The key to such an approach would be to ascertain what most strongly motivates members of Congress. If members are motivated most strongly by a desire for reelection, some dynamic based on this motivation probably leads current members to vote for unbalanced budgets. Any attempted solution that ignores this dynamic is likely to result in congressional efforts to circumvent. rather than implement, the solution. A solution that correctly identifies and builds upon members' motivations, however, may induce Congress to balance the budget

306. To the extent that Congress's budgetary fallings are attributuble to the fact that it is a collecture body, assigning the task of developing a default solution to the President might solse the problem Yione of the principal arguments generally made in favor of a constutuonal amendment focuses on this aspect of congressional decisionmaking. See supra Secton I.B.

307. The concept for this Article developed out of a tax policy seminar that i taught tho years ago One of the tasks I assigned my students in connection with a unit on the tax legislatuse process was to draft a balanced budget amendment. More than half the students submitted draft amendments employing incentive-based solutions. Although none of the techniques employed uould likely be tahen seriously in the public debate, the experience demonstrated the intustuve appeal of approaches that attempi to adjust legislative incentive structures directly.

308. See supra note 58.

309. See id. 
itself. For example, if we conclude that a desire for reelection most strongly motivates the average member, an amendment employing an incentive-based solution might offer an electoral advantage to all members of any Congress that complies with the target or, conversely, impose an electoral disadvantage on all members of any Congress that fails to comply.

There are obvious problems with such an approach. We may conclude that members' motivations are too varied to permit generalization. Even if we conclude that the average member is most strongly motivated by a desire for reelection, we might be reluctant, for reasons having to do with the integrity of the electoral process, to give incumbents any advantage or disadvantage. The fact that no one has yet suggested a plausible exemplar of the approach, moreover, may indicate that the approach is unworkable.

In theory, however, incentive-based solutions solve the major problems inherent in other approaches. They do not require any shift in the balance of powers. They leave to Congress all decisions about what spending to cut or which taxes to raise. Indeed, if the incentive is applied to incumbents as a group, an incentive-based solution might even lead members of different parties to cooperate to meet the amendment's budgetary target. An incentive-based solution-if one could be found-that shifts the market for legislation just enough to lead Congress routinely to comply with targets set by an independent scorekeeper might just solve our budgetary problems while preserving our basic democratic structures.

\section{Who Should Decide?}

We may not be able to design a fully satisfactory process for the definition of default solutions for some time to come. This leads to a further question: Should we, in the meantime, authorize extraordinary processes for the consideration and resolution of the process question itself? As has been noted, the 1995-96 Senate Draft may be interpreted to grant Congress superlegislative power to experiment with enforcement procedures that might otherwise be unconstitutional. Who should design an amendment's enforcement procedures: Congress and the states through the amendment process? Congress by majority vote? Or some other body or process?

A priori, one might not expect this to be an issue. Many, if not most of us, would assume without question that at least the core enforcement procedures should be defined in the amendment itself. The issue is raised, however, by ambiguities in the 1995-96 Senate Draft. Given the political importance of that draft, explicit consideration of the issue is required.

Section 6 of the 1995-96 Senate Draft specifies that: "The Congress shall enforce and implement this article by appropriate legislation, which may rely on 
estimates of outlays and receipts." 310 Initially, this sentence might appear routine and uninteresting. After all, many constitutional amendments have contained language authorizing Congress to implement their substantive provisions by statute. ${ }^{311}$ The problem here, however, is that Congress already has complete authority to define its own budgetary procedures, ${ }^{312}$ subject to separation of powers and similar limitations. In other contexts, amendment authors have had to deal with the problem that Congress is a legislature of enumerated powers; implementing language was necessary to extend Congress's authority to encompass the subject matter of the amendment in question. Here, however, there is no need for such an extension. Unless the first sentence is to be construed as surplusage, it must have some other meaning.

An alternative construction is that the sentence gives Congress the power to structure implementing procedures that would otherwise be unconstitutional: in effect, that it amends Article V of the Constitution. The scope of this power, however, is undefined in the text of the draft itself. Would the sentence permit Congress to override Bowsher v. Synar, ${ }^{313}$ which held that reposing the scorekeeping function in the Comptroller General violates the separation of powers? Would it permit Congress to override the ordinary rule that subsequent laws supersede prior laws $?^{314}$ Would it authorize implementing procedures that reverse the normal legislative process-permitting presidential enactment subject to legislative veto $?^{315}$ Would it allow Congress to structure incentive-based solutions by regulating eligibility or other terms for the election of its own membership?

Some guidance was provided by the 1995 Senate committee report, which seemed to focus on the word "shall." The report stated: "This section makes explicit what is implicit, that Congress has a positive obligation to fashion legislation to enforce this article." ${ }^{316}$ With respect to the scope of any possible power to structure enforcement procedures that might otherwise be unconstitutional, the report stated: "The provision precludes any interpretation

310. S.J. Res. 1, 104th Cong. $\$ 6$ (1995), reprinted in Appendix

311. See U.S. CONST. amend. XIII, $\S 2 ; i d$. amend. XIV. $\$ 5 ;$ id. amend. XV. $\$ 2$, ud amend XVIII. $\S 2 ;$ id. amend. XIX; id. amend. XXIII, $\$ 2 ;$ id. amend. XXIV. $\$ 2 ;$ id amend. XXVI. $\$ 2$

312. See S. REP. No. 104-5, at 9 (1995) ("The Constitution already empouers Congress with such authority.").

313. 478 U.S. 714 (1986).

314. See, e.g., Fisons Lid. v. United States, 458 F.2d 1241. 1245 (7th Cir 1972) (holding that later statute prevails); Ely v. Velde, 451 F.2d 1130. 1134 (4th Cir. 1971) (same): International (inion of Elce. Radio \& Mach. Workers v. NLRB, 289 F.2d 757 (D.C. Cir. 1960) (same). Eisenberg 、 Corming. 179 F 2d 275, 277 (D.C. Cir. 1949) (same); United States v. Wnghtwood Dann Co., 127 F2d 907. 912 (7th Cir 1942) (same).

315. The Supreme Cour has held that a one-house legislatuse seto volates the Article I requutrements of bicameralism and presentment. See INS v. Chadha, 462 U S 919 (1983). The Cour's reasoning suggests that all legislative vetos are constitutionally problematıc. See. $\mathrm{g}$. Consumers Linon $\mathrm{V}$ Federal Trade Comm'n, 691 F.2d 575 (D.C. Cir. 1982) (finding (wo-house legislatuse veto unconstitutional), aff 'd mem. 463 U.S. 1216 (1983).

316. S. REP. NO. 104-5, at 18. 
of the amendment that would result in a shift in the balance of powers among the branches of government."317 Unfortunately, this sentence-the only one that addressed the possibility of superlegislative power-purported to limit "interpretation," not implementation; it prohibited a "shift in the balance of powers," perhaps a narrower concern than a violation of the separation of powers; ${ }^{318}$ and it was silent with respect to many other possible enforcement techniques currently considered unconstitutional.

These interpretive problems are exacerbated by the second sentence of the same section, which provides that " $\mathrm{t}] \mathrm{he}$ judicial power of the United States shall not extend to any case or controversy arising under this Article" except with Congress's express consent. ${ }^{319}$ The sentence thus purports to limit the first sentence of Article III, Section 2 of the Constitution, which states in part that " $[t]$ he judicial Power shall extend to all Cases, in Law and Equity, arising under this Constitution" ${ }^{\prime 20}$ and which in turn underlies the power of judicial review articulated in Marbury v. Madison. ${ }^{321}$

The scope of this limitation, however, is not clear. It depends largely on the meaning of the phrase "arising under." Unfortunately, that phrase has at least two well-established meanings; it is not clear which meaning (if either) the 1995-96 Senate Draft is intended to invoke. For purposes of Article III, Section 2 of the Constitution-the provision that the 1995-96 Senate Draft purports to limit and therefore perhaps the most relevant-the Supreme Court has adopted a broad construction of the phrase. In Osborn v. Bank of the United States, ${ }^{322}$ the Court stated that a case would be treated as "arising under" the Constitution if "the title or right set up by the party, may be defeated by one construction of the constitution or law of the United States, and sustained by the opposite construction." ${ }^{323}$ Osborn was reaffirmed in 1983 in Verlinden B.V.v. Central Bank of Nigeria. ${ }^{324}$ Characterizing Osborn as " $[t]$ he controlling decision on the scope of Art. III 'arising under' jurisdiction," the Court stated that Osborn "reflects a broad conception of 'arising under' jurisdiction, according to which Congress may confer on the federal courts jurisdiction over any case or controversy that might call for the application of federal law." 325 Were this meaning to be adopted for purposes of section 6 of the 1995-96 Senate Draft, the result would be to deprive federal courts of the power to review the constitutionality of any legislation that might be sustained or defeated by any

317. $I d$.

318. Cf. id. at 15 ("Nothing in [section 1] either anticipates nor [sic] requires any atteration in the balance of powers between the legislative and executive branches.").

319. S.J. Res. 1, 104th Cong. $\$ 6$ (1995), reprinted in Appendix.

320. U.S. CONST. art. III, $\S 2$.

321. 5 U.S. (1 Cranch) 137 (1803).

322. 22 U.S. (9 Wheat.) 738 (1824).

323. Id. at 822. See generally ERWIN ChEMERINSKY, FEDERAL JURISDICTION $§ 5.2 .2$, at 256-59 (2d

ed. 1994) (describing Osborn as seminal case interpreting federal question jurisdiction under Article III).

324. 461 U.S. 480 (1983).

325. Id. at 492 . 
construction of the draft itself, including, presumably, the first sentence of section 6. The effect would be to insulate from judicial review any legislation purporting to be authorized by that sentence-a very broad exemption indeed.

This is not, of course, the only possible interpretation. The same phrase has been given a narrower meaning for purposes of the federal question jurisdiction statute, which states that "[t]he district courts shall have original jurisdiction of all civil actions arising under the Constitution, laws, or treaties of the United States." ${ }^{326}$ In this context, "a case arises under federal law if it is apparent from the face of the plaintiff's complaint either that the plaintiff's cause of action was created by federal law; or . . that a federal law that creates a cause of action is an essential component of the plaintiff's claim." 327 How such an interpretation might be applied to section 6 of the 1995-96 Senate Draft is not clear. The section might, however, be interpreted to mean that no cause of action exists to enforce the amendment directly except as explicitly provided by Congress. ${ }^{328}$ Under such an interpretation, a plaintiff might still challenge laws enacted pursuant to that section as violative of other parts of the Constitution.

The problem, therefore, is not that section 6 requires an overly broad interpretation. The problem is rather that it plausibly permits one. At the extreme, it may be construed to authorize Congress to enact otherwise unconstitutional procedures to enforce the amendment and preclude judicial review of the constitutionality of such enactments without any obvious limits to such unreviewable superlegislative powers.

It may be objected that the evident purpose of the second sentence of section 6 was a narrow one: to address Senator Nunn's concern that courts would themselves undertake to define the default solution. Although this may be true, the relevance of legislative intent has been challenged in recent ycars, cven in the interpretation of statutes. ${ }^{329}$ There is little reason to believe that Congress has the power, through committee reports and statements on the floor, to control the

326. 28 U.S.C. $\S 1331$ (1994).

327. See CHEMERINSKY, supra note 323, $\S 5.2 .3$, at 263

328. Such an interpretation would still leave open many questions. Could the amendment be asserted as a defense to a cause of action? Assume, for example, that the Prestdent impounds funds, ostensibly pursuant to section 1 of the amendment. Members of Congress sue. assering that such impoundment is impermissible. Could the President plead the amendment in defense. notwithstanding section 6 ' It is also unclear whether the amendment could be assened affimatively as part of a cause of action authonzed pursuant to another provision of the Constitution. Consider. for example, a sust to enjoin the trustees of a pension fund from purchasing U.S. bonds allegedly issued in wolstion of section 2 Such a suil would not "arise under" the amendment under the narrowest possible interpretation of that phrase. nevertheless, suits of this nature might well be structured to enforce very significant aspects of the amendment

329. See, e.g., Daniel A. Farber \& Philip P. Fnchcy. Legislome Intent and Public Chouce. 74 VA L REV. 423 (1988) (examining public choice critique of use of legislatuve intent in statutory construction). Bradley C. Karkkainen. "Plain Meaning": Justice Scalia's Jurtsprudence of Strict Statuton Construction. 17 HARV. J.L. \& PUB. POL'Y 401 (1994) (discussing Justice Scalı's view of urrelevance of legislalive intent); Kenneth A. Shepsle, Congress Is a "They. "Not an "Il": Legisiarve Intent as Orumoron, 12 IVT"L REV. L. \& ECON. 239 (1992) (asserting that legislative intent has no meaning). But of William N Eskndge. Jr., Cycling Legislative Intent, 12 INT'L REv. L. \& ECON. 260 (1992) (offenng cntıque of Shepsle) 
interpretation of any constitutional amendment over the next two hundred years, let alone over the next decade.

Is it appropriate to give Congress superlegislative powers to structure enforcement procedures for the amendment that would otherwise violate existing constitutional principles? A thoroughgoing exploration of the problem is beyond the scope of this Article. Three preliminary observations, however, are worth making. First, Congress's failure to date to develop a satisfactory approach to the problem of enforcement is attributable only partially to the difficulty of the problem. Congress has been distracted by the politics of the balanced budget problem. I remain optimistic that one or more satisfactory solutions may be forthcoming in the not-too-distant future, provided that serious and less partisan attention is given to the problem. There may be no need to amend the amendment process. Second, if Congress has an institutional bias in favor of unbalanced budgets, it seems unlikely that effective enforcement provisions would long survive an arrangement under which Congress has the power, by majority vote, to render such provisions ineffective. It may be possible to gather briefly the political will to propose and ratify an amendment containing effective enforcement provisions. It is far less likely that the same level of vigilance can be maintained indefinitely. The most likely long-term outcome, if Congress has the power to control enforcement, is that enforcement will be spotty and ultimately ineffective. Finally, even if it is concluded that giving Congress superlegislative powers is appropriate in this context, any such grant of power should be explicit and well-defined. Had the 1995-96 Senate Draft been proposed and ratified, its proponents, particularly in the state legislatures, might have been unpleasantly surprised by an interpretation that expanded, rather than restricted, congressional power. The amendment process should not be amended without full debate of the issues presented, and the scope of superlegislative powers granted to Congress should be clearly defined in advance.

My suspicion is that section 6, in its current form, will not long survive informed debate. Arguments in favor of putting the fox in charge of the henhouse are suspect, particularly when the proposal is made by the fox. The common intuition that enforcement procedures should be specified in the amendment itself, not left to Congress, is probably correct.

\section{Waiving the Amendment: Who, When, and How?}

A final aspect of the enforcement problem is specifying when and how the requirements of the amendment may be waived. It is impossible to predict all circumstances in which waiver might be necessary. Some open-ended provision for waiver therefore seems essential. If waiver is too easy, the amendment will have no teeth. If it is too difficult, the nation may find itself unable to meet 
extraordinary challenges or take advantage of extraordinary opportunities. How, then, should provisions for waiver be structured?

The simplest approach is to permit a waiver only upon a supermajority vote of each house of Congress. A majority may make policy, but only a supermajority may breach fiscal discipline. The 1995-96 Senate Draft, for example, permits a waiver of the requirements of both section 1 and section 2 for any reason upon a sixty percent rollcall vote of each house. ${ }^{330}$

Some have been troubled by the resulting infringement on majoritarian rule. ${ }^{331}$ A supermajority waiver provision is ultimately no different in concept, however, from the Article $V$ requirement that a supermajority approve constitutional amendments. Thus a balanced budget waiver can be viewed as a temporary suspension of one portion of the Constitution. So viewed, the supermajority requirement seems less objectionable.

Some have predicted that a supermajority waiver provision would trigger further congressional gridlock. ${ }^{332}$ This outcome would certainly have been true under the 1995-96 Senate Draft, which effectively authorized hostagetaking. ${ }^{333}$ In an environment that rewards hostage-taking, supermajority provisions merely exacerbate the problem. However, in an amendment relying on some more rational enforcement mechanism-for example, one incorporating an incentive-based solution-a supermajority waiver provision would not necessarily create the same opportunities or incentives for obstructionist legislative behavior.

No one has yet proposed an acceptable alternative to the supermajority waiver requirement. Because extraordinary events likely to trigger a waiver almost inevitably present political issues, the issue of waiver should be left to the political branches. It would be inappropriate, for example, to permit an unelected body to decide that the nation cannot incur debt to make the next Louisiana Purchase if supermajorities in each house of Congress plus the

330. See S.J. Res. 1, 104th Cong. \$§ 1-2 (1995). reprinied in Appendix

331. See, e.g., S. REP. No. 104-5, at 54-59 (1995) (minonis vews of Sens Kennedy. Leahy, and Feingold); 1995 House Hearings, supra note 2. at 113 (statement of Altce M. Rushn. Director. Office of Management and Budget) (asserting that supermajority provisions infringe on majontanan rule). 1983-8. Senate Hearings, supra note 2, at 81 (statement of Professor Rober D Goldstein) (same), id at 121 (statement of Steven A. Reiss on behalf of Association of the Bar of the Caly of New York) (same). 1979-80 House Hearings, supra note 2, at 284 (statement of Rep Ullman) (same). ul at 378, 380 (statement of Rep. Giaimo) (same); id. at 423-24 (1979-80) (statement of Rep Mlineta) (sume). id at 496-97 (statement of Laurence Gold, Special Counsel. Amencan Federation of Labor and Congress of Industrial Organizations) (same).

332. See, e.g., S. REP. No. 104-5, at 32 (minority view's of Sens. Kennedy, Leahy, and Feingold). 1995 House Hearings, supra note 2, at 14, 16 (statement of Charles L. Schultze. Senıor Fellow. Brookings Institution) (predicting greater gridlock): id. at 108 (statement of Rep Scoll) (same): id. at 111. 113 (statement of Alice M. Rivlin, Director, Office of Management and Budget) (same). 1983-\$4 Senate Hearings, supra note 2, at 79,80 (statement of Professor Roben D. Goldstein) (same). Id at 121 (statement of Steven A. Reiss on behalf of Association of the Bar of the City of New Yorh) (same). 1979-80 House Hearings, supra note 2, at 101, 106 (statement of Charles L. Schuitze, Chasman. Councal of Economic Advisers) (same).

333. See supra notes $273-75$ and accompanying text 
President-as close to consensus as may be possible in a democratic society short of a constitutional amendment-conclude that we should.

Two special situations merit separate consideration. First, some argue that Congress should be permitted to waive the amendment by majority vote in the event of adverse economic conditions. ${ }^{334}$ This proposition seems both unwise and unnecessary. Although politicians often find it in their self-interest to find fault with the national economy, it is not clear that elected representatives bring any expertise or legitimacy to economic decisionmaking. To permit waiver by majority vote whenever the economy is perceived to be performing suboptimally would seriously threaten the enforceability of the amendment. In addition, were an amendment to delegate the task of target setting to an independent scorekeeper, as I have suggested, such a waiver would be unnecessary.

It is also sometimes argued that Congress should be permitted to waive the amendment by majority vote in the event of a declared war or other serious military conflict. Section 5 of the 1995-96 Senate Draft, for example, provides:

The Congress may waive the provisions of this article for any fiscal year in which a declaration of war is in effect. The provisions of this article may be waived for any fiscal year in which the United States is engaged in military conflict which causes an imminent and serious military threat to national security and is so declared by a joint resolution, adopted by a majority of the whole number of each House, which becomes law. ${ }^{335}$

Under this provision, the 1995 Senate committee report argued, "Congress will retain maximum flexibility in responding to clear national security crises such as a declared war or imminent military threat to national security." 336

At first glance, these national security arguments are inherently appealing. Upon further consideration, however, they may actually be less compelling. The question is not whether a supermajority vote should be required for the United States to defend itself. The question is rather whether involvement in a military conflict should permit a bare majority to authorize a collapse of

334. For example, Representative Owens proposed an amendment to the 1995 House draft that "would have permitted Congress to waive the provisions by law any year for which the President notified Congress and Congress adopted a joint resolution affirming that the national unemployment rate was projected to exceed four percent." 141 CoNG. REC. D95-96 (daily ed. Jan. 26, 1995). The Owens amendment was defeated by a vote of 363 to 64 . See id. Representative Wise similarly proposed an amendment to the 1995 House draft that would have permitted Congress to waive the amendment in times of recession as declared by law; the Wise amendment was defeated by a vote of 291 to 138. See id. In the Senate, Sen. Nunn proposed an amendment to the 1995-96 Senate Draft that would have permitted waiver for any fiscal year "if, with respect to that fiscal year, the Senate and the House of Representatives agree to a concurrent resolution stating, in substance, that a national emergency requires the suspension of the application of this article for that fiscal year." 141 CONG. REC. S2970 (daily ed. Feb. 22, 1995). This proposal was tabled by a vote of 61 to 39. See 141 CONG. REC. D254 (daily ed. Feb. 28, 1995).

335. S.J. Res. 1, 104th Cong. $\$ 5$ (1995), reprinted in Appendix.

336. S. REP. No. 104-5, at 17 . 
fiscal discipline for an entire fiscal year on "national security" grounds. The potential for abuse is large. The 1995 Senate committee report implies that section 5 is intended to give Congress wide latitude. The phrase "imminent and serious military threat to national security," the report states "is intended to define those situations in which Congress, in order to respond to urgent national security crises with additional outlays for the defense of the Nation, needs more flexibility than the three-fifths vote requirement in section 1 would provide. ${ }^{" 337}$ In other words, in a dangerous world, a majority vote waiver is available whenever Congress needs it.

Perhaps the most authoritative views on the scope of such a waiver provision are those of Senator Heflin, the author and principal advocate of the above-quoted section 5. In a statement appended to the 1995 Senate committee report, the Senator noted that in the 220 years of this nation's history, there were some " 200 instances in which the United States has used military forces abroad in situations of conflict, ${ }^{338}$ raising the disquieting possibility that all or many of such conflicts might have justified a waiver. Among the conflicts he implied were sufficiently serious were the seizure of the Mayaguez by North Korea in 1975, the U.S. intervention in the Dominican Republic in 1965, the U.S. intervention in Lebanon in 1958, and the confrontation in the Formosa Straits in $1955 . .^{339}$ While these events were serious in their own way, their inclusion in his statement means that the phrase "imminent and serious military threat to national security" is less restrictive than some might expect. The past several years have seen comparable or greater U.S. military involvement in Bosnia, Haiti, Somalia, the Persian Gulf, Panama, and Grenada. One may wonder whether, under such a provision, waiver might become the rule rather than the exception.

At the same time, waiver by majority vote may not be sufficient to protect national security interests. Most spending to prepare for military crises occurs well in advance of any intervention, and could not be deficit-financed under the 1995-96 Senate Draft without a supermajority waiver which, in the absence of an immediate danger, may be difficult to achieve. ${ }^{300}$ Only longerterm military conflicts require spending increases that cannot be accommodated with relatively minor budgetary adjustments; it is precisely those commitments, however, that most clearly require responsible financing. ${ }^{3.1}$

337. Id. at 18.

338. Id. at 71 (additional views of Sen. Hefin).

339. See id. at 71-72.

340. See id. at 17 ("The committee intends that ordinary and prudent preparations for a wat percerved by Congress to be imminent would be funded fully within the lamiations imposed by the amendment. although Congress could establish higher levels of spending or deficits for these or any other purposes under section 1.").

341. There is a further serious problem with a rule that permits waser by majonly vote only in the event of military confilict: Such a rule creates a constitutional bias in fas or of war Consider. for example, the Louisiana Purchase. In 1803, sentiment to take the lower Mississippi by foree was running high The United States had a choice; it could either go to war or acquire the temtory peacefully See, e g. HeNRY 
The problem is a difficult one. While the solution adopted by the 1995-96 Senate Draft is not entirely satisfactory, it is not clear that a better solution is yet at hand.

\section{CONCLUSION}

This Article has deliberately taken no position as to whether a constitutional amendment to require a balanced federal budget is a good idea; in fact, I am agnostic on this issue. What I do assert is that if we are going to adopt such an amendment, it should be well-drafted. Proposal and ratification of a poorly drafted amendment will likely do more harm than good, even if we conclude that such an amendment is, in concept, a good idea. The 1995-96 Senate Draft, the draft balanced budget amendment twice considered and twice defeated by the 104th Congress, was, I suggest, severely flawed.

Of the many issues I have raised, three are most important. First is the problem of circumvention. The cash method of accounting invoked by the 1995-96 Senate Draft is too porous and too primitive to be effective. I have outlined a number of circumvention techniques that take advantage of deficiencies in the cash method. My examples are merely illustrative; many more exist. Control over the scope of the amendment is also essential to effective enforcement, but the line drawn by the 1995-96 Senate Draft would leave this within Congress's control. Congress would continue to be free to spend and incur debt beyond the amendment's parameters while claiming nominal compliance with the amendment's requirements.

For these and other reasons, I have suggested that effective enforcement of a balanced budget amendment requires an independent scorekeeper. Such a scorekeeper could define accounting rules that implement the values underlying the amendment. It could police attempts to move spending and debt off-budget. It could, in sum, minimize the possibility that a balanced budget amendment would merely provide political cover for continued "blue smoke and mirrors" budgeting. Such a scorekeeper would not necessarily have any power to enforce. Credible scorekeeping, however, is an essential first step.

A second important practical problem is the macroeconomic impact of a balanced budget amendment. No effective formulaic solution has been found

\footnotetext{
ADAMS, History OF THE UNITED STATES OF AMERICA DURING THE ADMINISTRATIONS OF THOMAS JEFFERSON 177-93 (1967) (detailing history of crisis leading to Louisiana Treaty of 1803); DUMAS MALONE, JEFFERSON THE PRESIDENT FIRST TERM 1801-1805, at 239-310 (1970) (same). Under section 5 of the 1995-96 Senate Draft, the military option would have required only a majority vote, see S.J. Res. 1, 104th Cong. $\$ 5$ (1995), reprinted in Appendix; whereas the peaceful solution would require a supermajority vote in each house, see id. $\$ 1$. International relations often present such choices. Should we negotiate or send the gunboats? Should we intervene or merely prepare to do so? If we are already involved, when should we make peace and on what terms? Any provision that allows Congress and the President to avoid the electoral pain of financial responsibility by provoking or continuing military engagement is quite dangerous.
} 
to this problem; congressional waiver by majority vote seems ill-advised. I have suggested that the amendment be drafted to define its target by reference to values rather than numeric tests. The scorekeeper would then be charged with setting the actual numeric tests from time to time, laking issues of macroeconomic impact into consideration.

Finally, there is the problem of imposing a remedy when Congress fails to comply voluntarily. The use of debt ceiling limitations, the 1995-96 Senate Draft's principal enforcement mechanism, is profoundly unsatisfactory. There is no guarantee that debt ceiling limitations will actually lead to reduced deficits; they are likely to lead to hostage-taking behavior by congressional minorities. Moreover, there is a real risk that they may lead to a default on the national debt-a risk that is simply unacceptable.

Proponents of a balanced budget amendment have become increasingly impatient. Impatience is sometimes a virtue. This is one context, however, in which a sound result is more important than a quick one. My message to Congress and the states is simply this: If you are going to do it, do it right. 


\section{APPENDIX}

Senate Joint Resolution 1, as amended and defeated March 2, 1995, and defeated on reconsideration on June 6, 1996 (“1995-96 Senate Draft")

"SECTION 1. Total outlays for any fiscal year shall not exceed total receipts for that fiscal year, unless three-fifths of the whole number of each House of Congress shall provide by law for a specific excess of outlays over receipts by a rollcall vote.

"SECTION 2. The limit on the debt of the United States held by the public shall not be increased, unless three-fifths of the whole number of each House shall provide by law for such an increase by a rollcall vote.

"SECTION 3. Prior to each fiscal year, the President shall transmit to the Congress a proposed budget for the United States Government for that fiscal year, in which total outlays do not exceed total receipts.

"SECTION 4. No bill to increase revenue shall become law unless approved by a majority of the whole number of each House by a rollcall vote.

"SECTION 5. The Congress may waive the provisions of this article for any fiscal year in which a declaration of war is in effect. The provisions of this article may be waived for any fiscal year in which the United States is engaged in military conflict which causes an imminent and serious military threat to national security and is so declared by a joint resolution, adopted by a majority of the whole number of each House, which becomes law.

"SECTION 6. The Congress shall enforce and implement this article by appropriate legislation, which may rely on estimates of outlays and receipts. The judicial power of the United States shall not extend to any case or controversy arising under this Article except as may be specifically authorized by legislation adopted pursuant to this section.

"SECTION 7. Total receipts shall include all receipts of the United States Government except those derived from borrowing. Total outlays shall include all outlays of the United States Government except for those for repayment of debt principal.

"SECTION 8. This article shall take effect beginning with fiscal year 2002 or with the second fiscal ycar beginning after its ratification, whichever is later." 